2014

\title{
A New Theory for Patent Subject Matter Eligibility: A Veblenian Perspective
}

Austen Zuege

Follow this and additional works at: https://open.mitchellhamline.edu/cybaris

\section{Recommended Citation}

Zuege, Austen (2014) "A New Theory for Patent Subject Matter Eligibility: A Veblenian Perspective," Cybaris $\AA$ : Vol. 5 : Iss. 2 , Article 1.

Available at: https://open.mitchellhamline.edu/cybaris/vol5/iss2/1

This Article is brought to you for free and open access by the Law Reviews and Journals at Mitchell Hamline Open Access. It has been accepted for inclusion in Cybaris ${ }^{\circledR}$ by an authorized administrator of Mitchell Hamline Open Access. For more information, please contact sean.felhofer@mitchellhamline.edu. (c) Mitchell Hamline School of Law

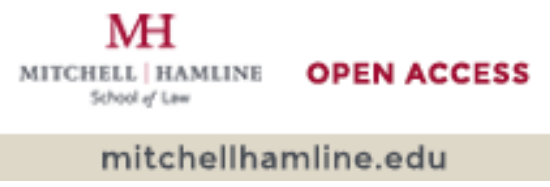




\section{A New Theory for Patent SubJect Matter Eligibility: A VEBLENIAN PERSPECTIVE}

AUSTEN ZUEGE ${ }^{\dagger}$

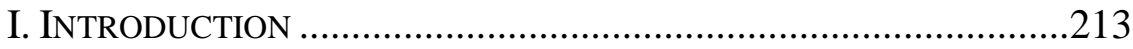

II. A BRIEF OVERVIEW OF VEBLEN ...........................................218

III. CHANGES IN THE MAKEUP AND CHARACTER OF THE UNITED STATES ECONOMY ...........................................................22

A. Why It Matters ............................................................227

B. Recent Expansion of the FIRE Sector .........................230

C. Blurring of Lines .........................................................239

D. Global Implications ....................................................242

IV. CHANGING JUDICIAL INTERPRETATIONS ...............................246

A. Historical Overview ......................................................246

B. Relative Consistency in Supreme Court Decisions .......250

C. Conflicting Views on the Federal Circuit ......................264

V. THE CONSTITUTIONAL LIMIT ................................................2270

VI. Assessing Patent Eligibility at the Point of INVENTIVE CONTRIBUTION ............................................276

VII. GENERAL CONTOURS OF THE NEW THEORY ..........................286

A. The Veblen Dichotomy .................................................28

${ }^{\dagger}$ Shareholder at the intellectual property law firm Kinney \& Lange, P.A. in Minneapolis, MN and registered patent attorney. The author wishes to thank Michael Collins and Larrin Bergman for providing comments and research suggestions during the preparation of this article, Wendy Bratten for research assistance, as well as the entire Cybaris ${ }^{\circledR}$ staff for citation checking and formatting assistance. All the views expressed in this article are the author's own and may not be those of Kinney \& Lange, P.A. or any of its clients. 
[5:211 2014] Cybaris@, AN INTELLECTUAL PROPERTy LaW ReVIEW 212

B. Economic Surplus and Productivity .............................294

C. Asset Relationships.....................................................298

D. Equal Access ...............................................................304

VIII. EXPLORING SOCIAL ASPECTS FOR PATENT ELIGIBILITY ANALYSIS IN A VEBLENIAN FRAMEWORK...........................307

A. The Nature of Pecuniary Activities ...............................307

B. Example Claim Analyses .............................................317

IX. The IMPORT OF THE NeW TheORY OF PATENT Eligibility ...332

A. The Veblenian Viewpoint and "Progress" of the "Useful Arts"............................................................332

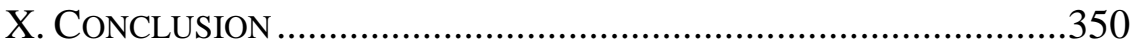




\section{INTRODUCTION}

What inventions are eligible for utility patent protection in the United States? The question, as simple as it appears, has been a topic of much heated debate. Courts have wrestled with the issue and have struggled to offer a cohesive and definitive standard. ${ }^{1}$ As a result, judicial decisions in this area have varied wildly, particularly with respect to determining what constitutes an unpatentable "abstract idea." ${ }^{2}$ Fundamental disagreements remain. Even when ostensibly applying the same standards, judicial opinions reveal a deep, underlying ideological divide about fundamental purposes of patents, the ends they advance, and who should benefit from them. In a practical sense, the most problematic claims for subject matter eligibility analysis are those that raise the perennial question of overbreadth, ${ }^{3}$ in which a relatively insignificant (or nonexistent) "inventive" contribution is recited (and therefore a monopoly secured) in relatively broad claims that greatly surpass the scope of the inventive contribution-or simply recite a result rather than the actual solution to the underlying technical problem. ${ }^{4}$

${ }^{1}$ E.g., CLS Bank Int'l v. Alice Corp. Pty. Ltd., 717 F.3d 1269 (Fed. Cir. 2013) (en banc) (per curiam), cert. granted, 82 U.S.L.W. 3131 (U.S. Dec. 6, 2013) (No. 13-298).

${ }^{2}$ E.g., compare Ultramercial, Inc. v. Hulu, LLC, 722 F.3d 1335 (Fed. Cir. 2013), with CyberSource Corp. v. Retail Decisions, Inc., 654 F.3d 1366 (Fed. Cir. 2011).

${ }^{3}$ Bernard Chao, Moderating Mayo, 107 Nw. U. L. Rev. ColloquY 82, 8990 (2012).

${ }^{4}$ Results- or effect-based claiming frequently arises through the use of functional (rather than structural) language, or through the recitation of method steps that relate to the physical world in only a vague, abstract way. It is, nonetheless, a problem that has existed for well over a hundred years, beginning with the introduction of claims in patent applications along with pre-grant examination in 1836. See, e.g., Le Roy v. Tatham, 55 U.S. (14 How.) 156, 173 (1852) ("A patent is not good for an effect, or the result of a certain process, as that would prohibit all other persons from making the same thing by any means 
Some key questions repeatedly arise when the patentability of business methods and other nontechnological activities are considered. Will protections of business methods displace technological endeavors, as historically understood? Should the grant of business method patents accommodate economic transitions that are alleged to flow from the so-called "postindustrial" economy, or does the Constitution, statutory language, or judicial gloss preclude patents from extending outside of the realm of "technology," more narrowly defined? Can patents on business methods ever be clearly distinguished from practical technology? These sorts of questions are central to an understanding of the deep ideological divide in the judiciary as evidenced by what are clearly conflicting patentable subject matter decisions. These inquiries illuminate the subtext of many disputes about the proper bounds of patent-eligible subject matter.

The Supreme Court has analyzed exceptions from patent eligibility under the doctrine of "preemption." Yet determining what does and does not constitute "preemption" remains a contentious issue. ${ }^{6}$ The lower courts and the U.S. Patent and Trademark Office ("USPTO") still struggle when patents and patent applications recite methods having tenuous links to tangible yet commonplace things like general purpose computers. In this legal quagmire, some degree of clarity might be found through reference to efforts in one of the last places patent attorneys look: the social sciences.

The present paper presents a possible extension of standards for patent eligibility based upon theories developed by economist Thorstein Veblen, who elaborated a dichotomy between

whatsoever. This, by creating monopolies, would discourage arts and manufactures, against the avowed policy of the patent laws.").

${ }^{5}$ E.g., Mayo Collab. Servs. v. Prometheus Labs, Inc., 132 S. Ct. 1289, 1294 (2012); Parker v. Flook, 437 U.S. 584, 595 (1978).

${ }^{6}$ Indeed, it is not clear that judges in lower courts are actually applying the preemption standard at all. See, e.g., Ultramercial, Inc. v. Hulu, LLC, 722 F.3d 1335, 1354 (Fed. Cir. 2013) (Lourie, J., concurring). 
economically productive and unproductive activity, extended from classical economics. ${ }^{7}$ This follows from Veblen's observations that patents represent ways of segregating the gains and transmission of technology, even though "in the case of [such] intangible assets there is no presumption that the objects of wealth involved have any serviceability at large, since they serve no materially productive work, but only a differential advantage to the owner in

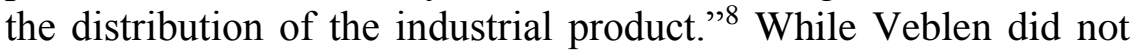
offer a precise test for determining patent subject matter eligibility, or even approach that question directly, he did provide a broad conceptual framework that can help illuminate a path toward a suitable patent eligibility standard, and, perhaps most importantly, can help evaluate various tests proffered to assess patent eligibility. The hope here is that a unification of many rationales given in judicial decisions over a period of centuries is possible by reclaiming the notion that patents must serve the social good, ${ }^{9}$ and that such a task can be accomplished using a Veblenian economic

7 Veblen is generally credited with coining the phrase "evolutionary economics." That term has taken on somewhat different meanings over time, and it now encompasses both orthodox and heterodox economic schools. The three leading schools of economic thought today are Neoclassical, Keynesian, and Marxist. See generally RiCHARD D. WOLFF \& STEPHEN A. RESNICK, CONTENDING ECONOMIC THEORIES: NEOCLASSICAL, KEYNESIAN, AND MARXIAN (2012). Neoclassical economics is considered "orthodox" while all others are considered "heterodox." Id. Veblen's work is considered heterodox; he was a critic of orthodox economics. He is variously described as either an evolutionary economist or an institutionalist economist.

8 ThORSTEIN VEBlen, THE INSTINCT OF WORKMANSHIP AND THE STATE OF THE INDUSTRIAL ARTS (1914), reprinted in WHAT VEBLEN TAUGHT 178-79 (Wesley C. Mitchell ed., Viking Press 1936) [hereinafter THE INDUSTRIAL ARTS]; Thorstein Veblen, On the Nature of Capital: Investment, Intangible Assets, and the Pecuniary Magnate, 23 Q.J. ECON., 104, 115 (1908), available at http://archive.org/details/jstor-1883967 [hereinafter On the Nature of Capital].

${ }^{9}$ An excellent discussion of just such a proposal is found in Dana R. Irwin, Paradise Lost in the Patent Law? Changing Visions of Technology in the Subject Matter Inquiry, 60 FLA. L. REV. 775 (2008); see also Bilski v. Kappos, 130 S. Ct. 3218, 3232, 3239-46 (2010) (Stevens, J., concurring). 
theory that aligns with the preemption doctrine that the Supreme Court has repeatedly relied upon.

The new theory presented here sets up a Veblenian dichotomy, whereby the productive functions of "technology" (or "industry") and unproductive "pecuniary" (or "ceremonial") functions are distinguished with respect to patent eligibility. The former provides means to support life processes in an evolutionary sense, whereas the latter merely deals with invidious human social relations-perhaps more broadly termed sociopolitical or socioeconomic endeavors. ${ }^{10}$ Patent claims directed to no more than accumulating or distributing wealth, manipulating confidence, exerting influence, avoiding regulation, structuring a business or legal organization, leveraging social position, speculating, and the like, would fall into the latter category, while patent claims directed to articles of manufacture, knowledge of the use of tools, application of "matter-of-fact" scientific knowledge, and the like, would fall into the former category. Key here is that any invention for which utility is contingent upon social context would not be patent-eligible. However, inventions that relate, in the very broadest sense, to applied physics and engineering with results that are repeatable, are independent of social context (i.e., transcultural), and bear some reasonable connection to creating an economic surplus based around overcoming the scarcity of labor, energy or materials in a causal sequence of development, would be patent-eligible. In short, this paper suggests using a Veblenian technological/pecuniary dichotomy to evaluate the constitutionality of judicial tests for patent eligibility, and further that such evaluations should be applied at the point of inventive

${ }^{10}$ See, e.g., ThorsteIN Veblen, THE THEORY OF THE LEISURE Class 232 (MacMillan 1899) ("The substantial canons of the leisure-class scheme of life are a conspicuous waste of time and substance and a withdrawal from the industrial process; while the particular aptitudes here in question assert themselves, on the economic side, in a deprecation of waste and of a futile manner of life, and in an impulse to participation in or identification with the life process, whether it be on the economic side or in any other of its phases or aspects.”); MichAEL HudSON, THE BUBBLE AND BEYOND 415 (2012). 
contribution, that is, by looking at where, in a given patent claim, a technical problem is alleged to be solved or a technical advance is otherwise alleged to be made. Such an approach is contrasted against other observations on patent eligibility, such as a suggestion by Thomas Cotter that a "Burkean" approach-based on the political outlook of Edmund Burke- -be employed. ${ }^{11}$

A Veblenian context for the patentable subject matter debate provides a way of evaluating proposed patentability tests. In other words, this provides a lens that can be used to test the tests for patent-eligible subject matter, by exploring the ideological and economic impacts of patent subject matter eligibility tests. Rather than force judges to evaluate an abstract question of degree (such as evaluation of the sufficiency of connections to tangible things) or make hypothetical comparisons (such as assessing whether a process could be performed purely mentally or whether other, unstated mechanisms can provide the same result), a shift toward a more functionally-oriented metric may allow more consistent outcomes by providing a shared sense of purpose in resolving the ambiguities that arise with the consideration of individual patent claims. Of course, the precise formulation of a bright-line functional metric is not the goal of this paper. Yet it is proposed that an evaluation of the contingency of a patent claim on social context to determine a relationship to a productive contribution to matter-of-fact technical knowledge may be a more useful form of analysis than one requiring a determination of whether a given invention could hypothetically be performed with purely mental steps, or whether there is a sufficient link to a machine or transformation of matter, as is often used to evaluate troublesome method claims in patents today. ${ }^{12}$

11 Thomas F. Cotter, A Burkean Perspective on Patent Eligibility, 22 BERKELEY TECH. L.J. 855 (2007).

${ }^{12}$ See, e.g., id. at 855, 884-94. 


\section{A BRIEF OVERVIEW OF VEBLEN}

Thorstein Veblen was a political economist raised in Minnesota, who has been called "one of the most important social thinkers of the last century[.]"13 $\mathrm{He}$ is frequently described as

13 Ian Rappel, Fight the Power, SOCIALIST REV., July 2005, available at http://www.socialistreview.org.uk/article.php?articlenumber=9461 (statement by Noam Chomsky). For background and other general information on Thorstein Veblen, see generally Ken MCCORMICK, VEBLEN IN PLAIN ENGLISH: A COMPLETE INTRODUCTION TO THORSTEIN VEBLEN'S ECONOMICS (2006); GEORGE SOULE, IDEAS OF THE GREAT ECONOMISTS 184-92 (1952); RICK TILMAN, THE LEGACY OF THORSTEIN VEBLEN (Rick Tilman ed., 2003); RicK TILMAN, THORSTEIN VeBLEN AND HIS CRITICS 1891-1963 (1992); THORSTEIN Veblen: CRITICAL Assessments (John Cunningham Wood ed., 1993); THORSTEIN VEBLEN: ECONOMICS FOR AN AGE OF CRISES (Erik S. Reinert \& Francesca Lidia Viano eds., 2012); John Patrick Diggins, Thorstein Veblen and the Literature of the Theory Class, 6 INT'L J. POL. Culture \& SOC'Y 481 (1993); William M. Dugger, Radical Institutionalism: Basic Concepts, 20 REV. RADICAL POL. ECON. 1 (1988), reprinted in 4 EVOluTIONARY THEORY IN THE SOCIAL SCIENCES 124 (Dugger et al. eds., 2003); Adil H. Mouhammed, A Critique of A Marxist Critique Of Thorstein Veblen, 6 AM. REv. POL. ECON., June 2008, at 19, available at http://arpejournal.com/ARPEvolume6number1/ Mouhammed.pdf; Rick Tilman, Thorstein Veblen (1857-1929), in A BIOGRAPHICAL DiCTIONARY OF DisSENTING ECONOMISTS 695 (Philip Arestis \& Malcolm Sawyer eds., 2d ed., 2000) [hereinafter Thorstein Veblen (1857-1929)] ("His most famous book [was] The Theory of the Leisure Class, in which he developed his theory of status emulation. In this satirical study of the leisure class and the underlying social strata which emulate it, he argued that conspicuous consumption, conspicuous waste and ostentatious avoidance of useful work were practices by which social status was enhanced.”); Andrew B. Trigg, Veblen, Bourdieu, and Conspicuous Consumption, 35 J. ECON. ISSUES 99 (2001) (linking Veblen to later theorists like Pierre Bourdieu); L. Randall Wray, Veblen's Theory of Business Enterprise and Keynes's Monetary Theory of Production, 41 J. ECON. IsSUES 1 (2007) (linking Veblen to later economists like Keynes). Some earlier economists, like John Rae, worked along similar lines. See, e.g., John RAE, Statement OF SOME NeW PRINCIPLES ON THE SubJeCt OF Political ECONOMY: EXPOSING THE FALlacies OF THE SySTEM OF FREE TRADE, AND OF SOME OTHER DOCTRINES MAINTAINED IN THE "WEALTH OF NATIONS" (1834), available at https://archive.org/details/ statementofsomen00raejrich; Anthony Brewer, John Rae on the Causes of Invention, http://citeseerx.ist.psu.edu/viewdoc/ 
having held Midwestern values in the sense of valuing workmanship, family, productivity and self-sufficiency, and opposing avaricious accumulation of wealth and power on the basis of social privilege, war, deception, sabotage, or looting. His theories were very egalitarian, ${ }^{14}$ and they included arguments that attacked misogyny, racism, jingoism, environmental destruction, and Social Darwinism. ${ }^{15}$ Much of his novel theoretical framework revolved around social drives toward unnecessary and wasteful consumption (competitive spending), the accumulation of wealth and other status-seeking actions brought about by invidious comparison with other persons, and similar human habits, motivations and social institutions, as distinguished from the way most economists focused on productive forces and marginal pricing. ${ }^{16} \mathrm{He}$ is famously credited with introducing the terms

download?doi=10.1.1.23.2702\&rep=rep1\&type=pdf $\quad$ last visited Sept. 16, 2013).

14 Phillip Anthony O'Hara, The Contemporary Relevance of Thorstein Veblen's Institutional-Evolutionary Political Economy, 35 HIST. ECON. REV. 78, 83 (2002), available at http://www.hetsa.org.au/pdf/35-A-7.pdf (explaining that Veblen's critical analysis was conducted with a view toward "[s]haring . . . [s] urplus product in a more egalitarian manner."); Dugger, supra note 13; VEBLEN, supra note 10, at 142 ("It may even be said that in the modern industrial communities the average, dispassionate sense of men says that the ideal human character is a character which makes for peace, good-will, and economic efficiency, rather than for a life of self-seeking, force, fraud, and mastery.").

15 William Dugger, Veblen's Radical Theory of Social Evolution, $40 \mathrm{~J}$. ECON. IsSUES 651 (2006); William M. Dugger, Veblen and Kropotkin on Human Evolution, 18 J. ECON. IsSUES 971 (1984); Ross E. Mitchell, Thorstein Veblen, Pioneer in Environmental Sociology, 14 ORG. \& ENV'T 389, 394-98 (2001).

16 See Barbara H. Fried, The Progressive AsSAUlt on LaISSEZ FaIre: ROBERT HALE AND THE FIRST LAW AND ECONOMICS MOVEMENT (1998); Michael Hudson, $M$ for Marginalism, MICHAEL-HudSON.COM (Jan. 22, 2014), http://michael-hudson.com/2014/01/m-for-marginalism ("[The marginalist] approach takes the technological and institutional environment as given rather than making policy and social reform the major aim of economic analysis, as was the case with classical political economy. The antitheses of marginalism are thus institutionalism and Systems Analysis .... [M]arginalist analysis is a 
"conspicuous consumption" and "conspicuous waste" to describe tendencies people have to make unproductive displays of their exemption from "vulgar" (real, productive) work, in order to reflect social status. ${ }^{17}$ However, Veblen saw more than just negative "acquisitive instincts" in humans; he also emphasized how the "parental bent" fostered care for future generations, "idle curiosity" fostered a benevolent search for knowledge, and the "instinct of workmanship" fostered the useful employment of science and technology. ${ }^{18} \mathrm{He}$ is therefore credited with introducing the modern meaning of the term "technology" to popular discourse in America. ${ }^{19}$

The conflict between "vested interests" dedicated to preserving an existing social order against changing circumstances and

synonym for asocial analysis.”); see also L. Randall Wray, MMP \#52 Conclusion: The Nature of Money, NEW ECON. PERSP. (June 27, 2012), http:// neweconomicperspectives.org/2012/06/mmp-51-conclusion-the-nature-ofmoney.html.

17 Veblen's views here coincide surprisingly with later Freudian and Lacanian theories of the human psychology of desire. See, e.g., Slavoj Žižek, From Che vuoi? to Fantasy: Lacan with Eyes Wide Shut, How TO READ LACAN, http://www.lacan.com/zizkubrick.htm (last visited Sept. 25, 2013) ("The original question of desire is not directly 'What do I want?', but 'What do others want from me? What do they see in me? What am I for the others?"). It is this aspect that most clearly differentiates Veblen's theories from the methodological individualism of orthodox neoclassical economics.

18 THE INDUSTRIAL ARTS, supra note 8, at 25. Veblen saw the instinct of workmanship rivaled only by the "parental bent" (with both competing with the acquisitive instinct); see also Erik S. Reinert, Civilizing Capitalism: "Good" and "Bad" Greed from the Enlightenment to Thorstein Veblen (1857-1929), 63 REAL-WORLD ECON. REV., Mar. 25, 2013, at 65, available at http:// www.paecon.net/PAEReview/issue63/whole63.pdf.

${ }^{19}$ Eric Schatzberg, Technik Comes to America: The Changing Meanings of Technology Before 1930, 46 TECH. \& CULTURE 486, 487-88, 498-507 (2006); see also Ronald Kline, Construing 'Technology' as 'Applied Science': Public Rhetoric of Scientists and Engineers in the United States, 1880-1945, 86 IsIS 194, 217 (1995). Veblen has further been credited with inventing the term "captains of industry," at least in its modern usage. SOULE, supra note 13, at 188. 
incursions from newcomers was of particular importance to Veblen. He assessed such conflicts through the interaction of technical, instinctive, and institutional factors. His greatest contributions arose from the warnings he issued about parasitic "pecuniary" interests siphoning off wealth created by industry, concluding that "a persistent excess of parasitic and wasteful efforts over productive industry must bring on a decline." ${ }^{20} \mathrm{He}$ was more astute than most at identifying the skillful sophistries of businessmen who were engaged in zero-sum battles over price differentials rather than contributing to production that benefitted the "generic ends of life." In that way he distinguished "the kind of self-interest which contributes to wealth creation from that which constitutes predatory wealth extraction." 21 By most accounts he was a reform-minded iconoclast, ${ }^{22}$ who broke away from neoclassical economics in large part because he found its methods unscientific. $^{23}$

20 Thorstein Veblen, THE THeOry of Business EnTERPRise 36 (photo. reprint 2013) (1904); see also Dan Little, Thorstein Veblen's Critique of the American System of Business, ECONOMIST's VIEW (Nov. 13, 2013), http:// economistsview.typepad.com/economistsview/2013/11/thorstein-veblens-

critique-of-the-american-system-of-business.html ("One of the central impressions that emerges from reading [Veblen's] The Theory of Business Enterprise is this: the modern American industrial economy is a coordinated system that requires many things to happen in sync with each other; but the owners of the components of this system often have strategic interests that lead them to take actions leading to de-synchronization and short-term crisis. There is a serious conflict of interest that exists between the interests of the owner and the needs of the system - and the public's interests are primarily served by a smoothly functioning system. So owners are in conflict with the broader interests of the public.").

${ }^{21}$ Reinert, supra note 18 , at 58.

${ }^{22}$ Soule, supra note 13, at 184-86, 190-92 (calling Veblen "the Bad Boy of American Economics").

${ }^{23}$ Veblen is credited with coining the term "neo-classical" to describe an economic school. Thorstein Veblen, The Preconceptions of Economic Science III, 14 Q.J. ECON. 240, 261 (1900). Neoclassical economics denotes "[t]he school that arose in the last quarter of the 19th century, stripping away the 
Those with visions of economics similar to Veblen's are frequently termed "institutionalist" economists, though the term "institutional economics" was not Veblen's and over time has been applied to a variety of different economic theories that do not always conform to Veblen's own. ${ }^{24}$ Within the realm of legal

classical concept of economic rent as unearned income. By the late 20th century the term 'neoclassical' had come to connote a deductive body of free-trade theory using circular reasoning by tautology, excluding discussion of property, debt and the financial sector's role in general, taking the existing institutional environment for granted." Michael Hudson, $N$ is for Neo-Serfdom, O for Offshore Banking, MiCHAEL-HuDSON.COM (Jan. 23, 2014), http://michaelhudson.com/2014/01/n-is-for-neo-serfdom-o-is-for-offshore-banking. Veblen was an early critic of the shift from classical economics toward the neoclassical school.

${ }^{24}$ Latter-day commentators generally describe Veblen as an institutionalist economist, though that term was coined by Walter H. Hamilton, not Veblen himself. Many later "new" or "neo-" institutionalists deviate significantly from Veblen's original theories. See, e.g., MALCOLM RUTHERFORD, THE INSTITUTIONALIST MOVEMENT IN AMERICAN ECONOMICS, 1918-1947 (2011); Malcolm Rutherford, Institutional Economics: Then and Now, 15 J. ECON. PERSP. 173 (2001). Somewhat begrudgingly, Veblen's theories are referred to generally as institutionalist ones in this paper. The Association for Evolutionary Economics is a contemporary organization that follows and extends Veblen's economic outlook. ASS'N FOR EVOLUTIONARY ECON., http://www.afee.net (last visited Sept. 13, 2013). Veblen's views are so pervasive, however, that some writers largely recreate his work without attribution. See, e.g., CHARLES H. FERGUSON, PREDATOR NATION: CORPORATE CRIMINALS, POLITICAL CORRUPTION, AND THE HIJACKING OF AMERICA (2013). Economists involved with post-Keynesian Modern Monetary Theory (MMT), such as those at the University of Missouri-Kansas City, have taken a great deal from Veblen's theories and applied them to contemporary contexts. In particular, MMT takes an endogenous view of money and suggests that acquisition of money is a goal unto itself in a capitalist economy, because "Veblen recognized money as an institution whereupon possession of money gives the holder power." Samuel Ellenbogen, Essays in Monetary Theory and Policy: On the Nature of Money (5), NEW ECON. PERSP. (Dec. 25, 2013), http://neweconomicperspectives.org/ 2013/12/essays-monetary-theory-policy-nature-money-5.html. This is echoed in the comment, attributed to either Alfred P. Sloan, Jr. or Thomas Murphy but possibly apocryphal, that General Motors is in the business of making money, not cars. 
thought, some of his ideas were adopted by legal realists in the original law and economics movement. ${ }^{25}$

Veblen was noted for taking an overtly Darwinian approach to economics, and attempting to apply an evolutionary scientific, sociological and anthropological approach to economic theory. ${ }^{26}$ That approach, combined with a special focus on the influence of social context, set Veblen and the other institutionalist economists apart from their orthodox, neoclassical counterparts. ${ }^{27}$ This also

${ }^{25}$ Robert Lee Hale and Justice William O. Douglas were perhaps the most noteworthy legal realists to rely on some of Veblen's theories. See, e.g., FRIED, supra note 16; Neil Duxbury, Robert Hale and the Economy of Legal Force, 53 MODERN L. REV. 421, 429-30 (1990); Ron Harris, The Encounters of Economic History and Legal History, 21 LAW \& HIST. REV. 297, 323 n.50 (2003); William $O$. Douglas and the Growing Power of the SEC, SEC. \& EXCHANGE COMMISSION HIST. SOC'Y, http://www.sechistorical.org/museum/galleries/ douglas/academia.php (last visited Mar. 31, 2014). Certainly, many others were strongly influenced by Veblen, such as Adolph Berle, Jr., who was part of President Franklin Roosevelt's "Brain Trust" and the author of a leading text on corporate governance. Charles O.T. O'Kelley, Berle and Veblen: An Intellectual Connection, 34 Seattle U. L. REV. 1317 (2011); ADOLPH A. BERLE, WiKIPEDIA, https://en.wikipedia.org/wiki/Adolf_A._Berle (last updated Feb. 4, 2014). To the extent that the later critical legal studies (CLS) movement traces its origins to legal realism, CLS lacks any coherent basis in Veblen's theories. Cornel West has remarked how this represents a failing of CLS. Cornel West, CLS and a Liberal Critic, 97 YALE L.J. 757, 770 (1988).

${ }^{26}$ Sophus A. Reinert, Darwin and the Body Politic: Schäffle, Veblen, and the Biological Metaphor Shift in Economics, in ALBERT SCHAFFLE (1821-1903): THE LEGACY OF AN UNDERESTIMATED ECONOMIST 129-52 (Jurgen Backhaus ed., 2010); see also Geoffrey M. Hodgson, Darwin, Veblen and the Problem of Causality in Economics, 23 HIST. \& PHIL. LIFE SCI. 385 (2001).

27 "The institutionalists view human behavior as a process of cumulative adaption to changing circumstances within the cultural context in which the behavior takes place. This view is acknowledged to be tentative and subject to change in the light of evidence to the contrary. Unlike the institutionalists, the orthodox economists make an a priori assumption about the nature of human behavior, and do not subject it to any testing process." William T. Waller, Jr., The Evolution of the Veblenian Dichotomy: Veblen, Hamilton, Ayres, and Foster, 16 J. ECON. IsSUES, 757 (1982); see also Erik S. Reinert, Neo-Classical Economics: A Trail of Economic Destruction Since the 1970s, 60 REAL-WORLD ECON. REV. 
makes Veblen an appealing reference point with regard to patent policy, which professes some relationship to scientific methodologies. Indeed, Albert Einstein - a former patent examiner no less-endorsed Veblen as a leading thinker on the philosophy of science in an economic context, and one of the only economists of his day worth reading. ${ }^{28}$ But readers should scrupulously avoid making too many assumptions about Veblen's views on patents from the present analysis, because his direct treatment of them was limited. ${ }^{29}$

2 (2012), available at http://www.paecon.net/PAEReview/issue60/whole60.pdf. Veblen's views here are precisely the opposite of those expressed by former British Prime Minister Margaret Thatcher, who once famously said, "And, you know, there is no such thing as society. There are individual men and women, and there are families." Douglas Keay, Aids, Education and the Year 2000!, WOMEN's OwN, Oct. 31, 1987, at 8-10.

${ }^{28}$ See, e.g., William T. Ganley, A Note on the Intellectual Connection between Albert Einstein and Thorstein Veblen, 31 J. ECON. ISSUES 245 (Mar. 1997); Albert EINSTEIN, IdEAS AND OPINIONS 19 (Schilpp trans., Bonanza 1988), translated in THE PHILOSOPHY OF BERTRAND Russell, VOL. V (Schilpp ed., trans., Tudor 1944), reprinted in IDEAS AND OPINIONS 19 (Crown Publishers 1954).

${ }^{29}$ In reading Veblen, although this boils down to idle speculation, one gets a sense that he viewed patents as, at best, a tolerable evil—perhaps even as a counterproductive mechanism for the pecuniary interests to sequester certain knowledge away from public use for private gain - and (like loan credit), to generally increase the costs of doing business at the inevitable expense of engineering efficiency. See, e.g., Veblen, On the Nature of Capital, supra note 8, at 115 n.1; ThORStein Veblen, The Place of SCIENCE IN MOdern CIVILISATION AND OTHER ESSAYS 186 (Ardzrooni et. al eds., 1919), available at https://archive.org/details/placeofsciencein00vebl; VEBLEN, supra note 20; see also Ken McCormick, Veblen and the New Growth Theory: Community as the Source of Capital's Productivity, 60 REv. Social ECON. 263 (2002); Jonathan Nitzan, Differential Accumulation: Towards a New Political Economy of Capital, 5 REV. INT'L POL. ECON. 169, 187 (1998). He seemed to view invention as something that would happen regardless of economic rent incentives. Richard V. Adkisson, Ceremonialism, Intellectual Property Rights, and Innovative Activity, 38 J. ECON. ISSUES 459, 461 (2004). Indeed, if the patent system evolved from political bargains struck in England with the Statute of Monopolies, discussed infra, then Veblen would have likely disapproved of 
One of the most distinctive aspects of Veblen's writing is the humorous, sarcastic and sardonic tone he frequently used, often to render backhanded insults against the rich and powerful. This made his writings, especially later ones, highly popular with general audiences, though in equal measure exposed him to criticism from his orthodox peers - many of whom, as apologists for privilege, were at least indirectly the subject of Veblen's insults. ${ }^{30}$ His archaic tone can sometimes require some patience and careful analysis. Unsympathetic readers often intentionally or unintentionally misread his humor. ${ }^{31}$ Yet his work remains highly relevant today, and is well worth reading first-hand.

patents on the basis of them giving too much weight to pecuniary interests. Still, given his emphasis on the accumulation of collective knowledge being of greater importance than any individual contributions, Veblen might have cautiously accepted what Roberto Mazzoleni and Richard Nelson called "Theory 2," that patents induce inventors to disclose inventions that they would otherwise tend to maintain in secrecy. Roberto Mazzoleni \& Richard R. Nelson, Economic Theories About the Benefits and Costs of Patents, 32 J. ECON. ISSUES 1031, 1033, 1038-40 (1998). For other compendiums of economic theories for patents, see Peter S. Menell, Intellectual Property: General Theories, in ENCYClOPEDIA OF LAW AND ECONOMICS, VOLUME II. CIVIL LAW AND ECONOMICS 129-48 (Bouckaert et. al eds., 2000); Patent Economics: Part 5 Theories, THE PATENT PROSPECTOR (Apr. 24, 2005), http:// www.patenthawk.com/blog/2005/04/patent_economics_part_5_theori.html;

Patent Economics: Part 4 - Incentives, THE PATENT ProsPeCtor (April 17, 2005), http://www.patenthawk.com/blog/2005/04/ patent_economics_part_4_incent.html. It is also worth noting that Veblen despised lawyers. He once wrote that "law schools belong in the modern university no more than a school of fencing or dancing." THORSTEIN VEBLEN, THE HiGHER LEARNING IN AMERICA 211 (1918).

30 J.A. Hobson, The Economics of Thorstein Veblen, 52 POL. SCI. Q. 139 (1937).

31 All this makes quoting Veblen in brief passages an almost useless endeavor, because his frequently sardonic and sarcastic tone requires that readers absorb the context he develops fully only across numerous pages or whole chapters of his writings. With that in mind, this paper often relies on secondary sources to condense Veblen's thought in a "drier" tone. 
The role of technology in society was crucial to Veblen's economic analysis, ${ }^{32}$ even if letters patents appear only peripherally in his work. Yet Veblen and his followers still offer practical theoretical frameworks that can inform the narrow question of patent subject matter eligibility. ${ }^{33}$ But before reaching those topics, a Veblenian and institutionalist approach requires the establishment of some context for the present-day patent-eligible subject matter debate, because quite clearly many specific social and economic circumstances have changed since Veblen's lifetime. ${ }^{34}$

32 Due to his extensive analysis on the role of technology in economic analysis, Veblen is sometimes wrongly characterized as having suggested, in a reductionist, deterministic, and technocratic way that technology is always positive. Olivier Brette, Thorstein Veblen's Theory of Institutional Change: Beyond Technological Determinism, 10 EUROPEAN J. HIST. ECON. THOUGHT 455 (2003), available at http://thorstein.veblen.free.fr/index.php/documents/65thorstein-veblen-theory-of-institutional-change-beyond-technology-and-

determinism-olivier-brette.html. Instead, "[t]he material and technical conditions are not an exogenous variable in Veblen's theoretical system. On the contrary, they stand in a system of interdependence in which they exert both a determining action on (individual and social) habits of action and thought and an action determined by the prevailing instinctive and institutional factors. Consequently, if technological progress is capable of leading to institutional changes, it is itself conditioned by the institutional logic and the instincts which prevail in society." Id. "In Veblen's system, technological progress is thus really an endogenous variable in the evolution process." Id. A fair analogy of Veblen's views is this: "The industrial arts . . . are the motor of the system, but the motor is fueled from outside, and the only controls that are applied from the inside are brakes of uncertain strength and holding power." Paul M. Sweezy, Veblen's Critique of the American Economy, 48 AM. ECON. REV., 21, 22 (1958).

33 See Adkisson, supra note 29, at 465 (noting that Veblen and similar thinkers offer insights to patent and other intellectual property policy); see also William B. BennetT, The American Patent System, An ECONOMiC INTERPRETATION (1943).

${ }^{34}$ Veblen died in 1929. Rick Tilman, Thorstein Veblen (1857-1929), supra note 13 , at 695 . 


\section{Changes IN THE MAKEUP AND CHARACTER OF THE UNITED STATES ECONOMY}

\section{A. Why It Matters}

In order to understand why judges, scholars, and practitioners have struggled so deeply and persistently with the question of patent eligibility in the present era, rather than another historical period, it helps to understand the changing social and economic context of the times. The U.S. economy has undergone great changes since the early 1970s, which have shaped the landscape in which the judiciary renders decisions in individual cases. In the aggregate, those decisions represent the judiciary's input on important social and economic policy questions. Questions of patent law are as bound to this economic context as any other area of law. It has previously been suggested by John Duffy that the rise of business method patents can be explained by the law following technology, in a reactive sense. ${ }^{35}$ At the broadest level such a view is compelling. But while Duffy astutely recognizes a new and emerging perspective on patent eligibility, he omits the economic context and therefore offers no critique of current patent policy from an economic perspective.

Economic circumstances play a large role in shaping the course of "invention" across an entire economy, and, in turn, shape the course of patent activity. Inventive activity always precedes patent activity. This rather straightforward observation merely emphasizes that there must be some "inventive" subject matter available to insert into a given patent application, as it were. But inventive activity exists only within a context of larger

35 John F. Duffy, Why Business Method Patents?, 63 STAN. L. ReV. 1247, 1263-68 (2011). This might be seen as a form of "cultural lag," which is to say that cultural institutions always lag behind current circumstances. Richard L. Brinkman \& June E. Brinkman, Cultural Lag: In the Tradition of Veblenian Economics, 40 J. ECON. ISSUES 1009 (2006). 
socioeconomic forces. ${ }^{36}$ The availability of resources to support and fund research often shape the development of inventions, facilitating some while precluding others. It has been argued that corporations, as entities that control significant resources, eventually came to largely dictate the circumstances and context for inventive activity. ${ }^{37}$ From there, it is hardly controversial to think that a shift of research funding from one area to another would have a corresponding impact on the degree of invention in those areas. Indeed, it is possible to picture "technology as a refractory yet periodically malleable expression of the distribution of power in society." 38 The ways in which scientific and engineering research is carried out have complex interactions with social orders, and are deeply affected by social, cultural and political biases and structures. ${ }^{39}$ From this perspective, changes in the makeup of the U.S. economy as a whole can be seen to influence what activities are (or are not) undertaken in significant volume that might generate patent applications. Such economic conditions can affect the gravitational pull, as it were, on trends in patenting and the framework for associated legal analysis, at any given time period. ${ }^{40}$

Historical examples can shed light on the economic contexts for debates over patent policy through the present. Steven

${ }^{36}$ See, e.g., THORSTEIN VEBLEN, IMPERIAL GERMANY AND THE INDUSTRIAL REVOLUTION (1915), available at https://archive.org/details/ imperialgermany01veblgoog.

37 CATHERINE L. FisK, WORKING KNOWLEDGe: EMPloyee INNOVATION AND THE RISE OF CORPORATE INTELLECTUAL PROPERTY, 1800-1930, at 177-210 (2009). This transition was fully realized during Veblen's lifetime.

38 Michael J. Piore \& Charles F. SABel, The Second Industrial DIVIDE 21 (1984); see also Langdon Winner, Do Artifacts Have Politics?, 109 DAEDALUS 121 (1980), available at http://zaphod.mindlab.umd.edu/ docSeminar/pdfs/Winner.pdf.

39 R.C. LEWONTIN ET AL., NOT IN OUR GENES: BIOLOGY, IDEOLOGY AND HUMAN NATURE 8 (1984).

40 See Pierre Bourdieu, The Social Structures of THE ECONOMy $226-$ 27 (Chris Turner trans., Polity Press 2005) (2000). 
Usselman and Richard John wrote a fascinating study of how tensions between railroad companies, farm interests, and independent inventors-based in large part on competing economic interests - shaped political battles over patent legislation in the 1870s. ${ }^{41}$ Among other salient points, Usselman and John note that for more than a hundred years independent proprietors (including "patent sharks") without first-hand access to expensive existing technology have long tended to produce lower-quality patent applications in the eyes of the "experts" who work for the owners of that existing technology, and that the very basis of the patent system has long been seen as a subsidy to urban regions to the detriment of rural ones. Such analyses highlight the sociopolitical aspects of how policies embedded in the patent system can create winners and losers-with one group's gains coming at another group's expense. The antebellum patent system found itself at the center of a debate of over spheres of influence as proprietary capitalism declined and corporate capitalism emerged. ${ }^{42}$ Back then, the debate was driven by the shift of economic opportunities from the Atlantic seaboard to the North American interior (a region of expanded U.S. influence after victory in the Mexican war of 1846-48). ${ }^{43}$ A similar struggle is happening today, merely with different groups and regions playing leading roles in the debate. As explored below, financial activities currently occupy a dominant role in the U.S. economy, and related business interests wield such significant influence that their relationships to the patent system are in need of continued analysis. ${ }^{44}$ These struggles are pronounced when considering the question of the proper scope of patent-eligible subject matter.

41 Steven W. Usselman \& Richard R. John, Patent Politics: Intellectual Property, the Railroad Industry, and the Problem of Monopoly, 18 J. POL'Y HIST. 96 (2006).

${ }^{42} I d$. at 120 .

${ }^{43}$ Id. at $98-99$.

${ }^{44}$ Much current study focuses on the roles of so-called "patent trolls." See, e.g., Michael D. Goldhaber, IP Insider: How Do You Say 'Troll' in Finnish?, 


\section{B. Recent Expansion of the FIRE Sector}

An extensive amount of analysis outside of the realm of patent law has focused on transformations of the economy in the United States in recent decades. Patent attorneys tend to ignore much of that literature. ${ }^{45}$ In this sometimes overlooked history, the concept of the "financialization" of the U.S. economy from the period of the 1970 s onward is discussed. ${ }^{46}$ These analyses, of course, are but

CORP. Couns., Nov. 2013, at 53-54. One study found that a growing share of all patent litigation brought by non-practicing entities involves business method patents, reaching approximately $41 \%$ in 2011-2012. Investigations into NPE Litigation Involving Business Method Patents, PAT. FREEDOM (Sept. 4, 2013), https://www.patentfreedom.com/wp-content/uploads/2013/09/NPE-Ligitationsinvolving-Business-Method-Patents_Sept-4-2013.pdf. This study may be underinclusive, in this author's view, due to the use of a fairly narrow definition of "business method."

${ }^{45}$ Indeed, legal scholars in general tend to ignore a great deal of economic and sociological scholarship, particular those from the period before and during the Great Depression that critiqued economic crises. Fred Block, Relational Work and the Law: Recapturing the Legal Realist Critique of Market Fundamentalism, 40 J.L. \& SOC'Y 27, 28-29 (2013) ("Mainstream legal thinking, particularly in the United States, has for some time faced a crisis in its understanding of economic activity. This crisis results from the marginalization of the key insights of legal realist scholars of the 1920s and 1930s who had developed a theoretically sophisticated analysis of the actual workings of markets."). Block notes that despite occasional references to Veblen, there has been relatively little work done in tracing out a historical lineage of economic sociology within the United States. Id. It is sadly common for patent attorneys to lack any familiarity with economists other than Joseph Schumpeter, and even then only on a cursory basis.

${ }^{46}$ See, e.g., Jacob Assa, Financialization and Its Consequences: The OECD Experience, 1 Fin. RES., Jan. 2012, at 35 (summarizing empirical data on recent financialization); Costas Lapavistas, Theorizing Financialization, 25 WORK, EMP. \& SOC'Y 611 (2011); Thomas I. Palley, Financialization: What It Is and Why It Matters 2 (Levy Institute, Working Paper No. 525, 2007), available at http://www.levyinstitute.org/pubs/wp_525.pdf. The asserted starting point for financialization varies. Some commentators place the date in the 1980s, while others indicate that it began in the 1970s and intensified in the 1980s. 
the latest in continued efforts to understand economic history. ${ }^{47}$ But to ignore these shifts in understanding is to potentially tether an understanding of patent law to a bygone era that does not reflect current situations and challenges.

Economists divide the overall economy into different sectors. One sector is referred to as the finance, insurance and real estate (FIRE) sector. ${ }^{48}$ Relative to other sectors, the domestic FIRE sector has grown dramatically in recent years. ${ }^{49}$ These large-scale, structural changes among different economic sectors are seen quite dramatically in the relevant data, particularly because the FIRE sector can "grow" by cannibalizing other sectors. ${ }^{50}$ Official U.S. government data from the Bureau of Economic Analysis shows that the FIRE sector overtook manufacturing in the 1980s in terms of gross domestic product (GDP), and as a percentage of corporate profits has begun to greatly surpass manufacturing since the 1990s. These trends are illustrated in Figures 1-3, which annotate the dates of the State Street Bank and Ex Parte Lundgren decisions that each expressed very broad views of patentable subject matter

47 For a discussion of the economic changes in the United States from the period of roughly World War I to 1970, see Michael Hudson, SUPER IMPERIALISM: THE ORIGINS AND FUNDAMENTALS OF U.S. WORLD DOMINANCE (new ed., 2003).

48 Michael Hudson, $F$ is for FIRE Sector, MichAEL-HudSON.COM (Sept. 23, 2013), http://michael-hudson.com/2013/09/f-is-for-fire-sector.

49 Robin Greenwood \& David Scharfstein, The Growth of Finance, $27 \mathrm{~J}$. ECON. PERSP., Spring 2013, at 3 (noting that FIRE sector growth is apparent "[w]hether one measures the financial sector by its share of gross domestic product, by the quantity of financial assets, by employment, or by average wages"); Özgür Orhangazi, "Financial" vs. "Real": An Overview of the Contradictory Role of Finance 1 (Political Economy Research Institute, Working Paper No. 274, 2011), available at http://www.peri.umass.edu/ fileadmin/pdf/working_papers/working_papers_251-300/WP274.pdf.

50 E.g., Reinert, supra note 27, at 7-11 (arguing that financial rents have displaced productive rents since the 1970s, and that Veblen has been unfairly ignored in analyzing that trend). 
that encompass business methods and the like. ${ }^{51}$ Over the same time period, employment declined significantly in manufacturing while increasing, albeit to a smaller degree, in the FIRE sector. ${ }^{52}$ Salaries and wages in the FIRE sector have also greatly outpaced those in other sectors. ${ }^{53}$ Some key characteristics of the modern economy are increased "rent based on privatized 'common knowledge,' . . . the much stronger structural role of unemployment," and the reduction of salaried professions (experts, administrators, public servants, doctors, lawyers, journalists, intellectuals, artists, etc.) to subsistence on more basic wages. ${ }^{54}$ These trends are linked to what is often called the rise of a "postindustrial" economy. ${ }^{55}$ Yet for all the sociologists originally

51 Bureau OF ECON. ANALYsis, U.S. DEP'T OF COMMERCE, GDP BY INDUSTRY / VA, GO, II, EMP (Dec. 15, 2011), http://www.bea.gov/industry/xls/ GDPbyInd_VA_NAICS_1947-1997.xls (containing statistics of industry value added based on the North American Industry Classification System data). The data illustrated in Figures 1-3 does not distinguish profits from financial activities by nonfinancial companies, a concept discussed further below.

52 TaE-HeE Jo \& JOHn F. Henry, TAKe THE MONey And Run: The Business ENTERPRise IN THE AgE OF MONEY MANAGER CAPITAlism 28-29 (2013), available at http://mpra.ub.uni-muenchen.de/48782 (citing U.S. Bureau of Economic Analysis data).

53 Greenwood \& Scharfstein, supra note 49, at 4-5.

54 SlaVOJ ŽIŽEK, THE YEAR OF DREAMING DANGEROUSLY 8 (2012) (citing JeAn-Claude Milner, Clartés de tOUt (2011)); see also Peter Drahos WITH JOHN BRAITHWAITE, INFORMATION FEUDALISM: WHO OWNS THE KNOWLEDGE ECONOMY? 1-3 (2002); Peter Drahos, Information Feudalism in the Information Society, 11 INFO. SOC'Y 209 (1995), available at http:// www.anu.edu.au/fellows/pdrahos/articles/pdfs/1995infofeudinfodociety.pdf.

55 The term "post-industrial society" first arose in the 1960s to describe a shift from a manufacturing-based economy to a more service-based economy, and has been attributed to various commentators. See, e.g., Daniel Bell, Notes on the Post-Industrial Society (I), 6 PUB. INT. 24 (1967), available at http:// www.nationalaffairs.com/public_interest/detail/notes-on-the-post-industrialsociety-i; Alain TOURAIne, THE POSt IndUSTRIAL SOCIETY: TOMORROW'S SOCIAL HISTORY (Leonard F. X. Mayhew trans., Wildwood House 1971) (1969). It should be noted that Bell was a vocal critic of Veblen, while Touraine was, relatively speaking, much more sympathetic. Similar terms like "information society" also began to arise around this time. See, e.g., FRITZ MACHLUP, THE 
writing on the topic of the so-called "post-industrial society," few recognized the possible parasitic role of the FIRE sector in the Veblenian sense. ${ }^{56}$ Certain economists working along Veblenian lines have explored that aspect in greater detail. ${ }^{57}$ For instance, economist Michael Hudson has said that recent circumstances "could almost as well be called a lapse back into the pre-industrial

PRODUCTION AND DISTRIBUTION OF KNOWLEDGE IN THE UNITED STATES (1962); YONEJI MASUDA, JOHO SHAKAI NYUMON [AN INTRODUCTION TO INFORMATION SOCIETY] (Pelikan-sha, Tokyo 1968). Today, it is noted that "[m]ajor industrial nations are, at the margin, moving away from the marketing of goods toward the renting of ideas." Robert T. Averitt, The Economics and Management of Intellectual Property: Towards Intellectual Capitalism by Ove Granstrand, 34 J. ECON. ISSUES 988, 989 (2000) (book review).

56 For instance, it has been shown that the present, second financial era (following a first that overlapped with Veblen's lifetime) had credit expansion leading to crises and busts. Moritz Schularick \& Alan M. Taylor, Credit Booms Gone Bust: Monetary Policy, Leverage Cycles, and Financial Crises, 1870 2008, 102 AM. ECON. REV. 1029 (2012), available at http://www.nber.org/ papers/w15512. "More money in relation to the size of the economy means that new money (i.e. new credit) is used mostly for buying up existing assets, not for enhancing production capacity." NORBERT HÄRING \& NIALL DOUGLAS, ECONOMISTS AND THE POWERFUL 79 (2012). Reference to the "post-industrial economy" often obscures and obfuscates such data and any associated conclusions. "The portmanteau term 'postindustrial society' failed to specify its basically financial aspect . . .." HUDSON, supra note 10, at 328; see also id. at $65,67,104,156,212,219,323,410$. The "post-industrial economy" is more like a "perpetual motion machine" and "might more accurately be called a rentier economy." NORBERT HÄRING \& NIALL DOUGLAS, ECONOMISTS AND THE POWERFUL 212 (2012).

57 E.g., Michael Hudson, I is for Ideology, MiCHAEL-HudSON.COM (Nov. 24, 2013), http://michael-hudson.com/2013/11/i-is-for-ideology (defining information economy as " $\mathrm{t}] \mathrm{h}$ he strategy of financial populism is to convince people that the economy's bottom $90 \%$ are best served by pursuing policies that favor the top $10 \%$. Stated more bluntly, parasitism succeeds by lying."). Anthropologists deserve some credit here too. For instance, David Graeber wrote a humorous article to this effect recently, discussing the rise of "bullshit jobs," among them administrative and finance jobs. David Graeber, On the Phenomenon of Bullshit Jobs, STRIKE! MAGAZINE, Summer 2013, at 10-11, available at http://www.strikemag.org/bullshit-jobs. 
usury and rent economy of European feudalism."58 Similarly, economist Hyman Minsky developed an alternative yet essentially synonymous concept of "money manager capitalism" to describe a stage arising out of welfare state capitalism that places industry in a back seat relationship relative to finance. ${ }^{59}$ Whatever the name, the effects are striking. As some hedge fund managers put it, "The money that's made from manufacturing stuff is a pittance in comparison to the amount of money made from shuffling money around . . . "60 These conditions are prone to arise when there is an

${ }^{58}$ Standard Schaefer, Who Benefited From the Tech Bubble?: An Interview With Michael Hudson, COUNTERPUNCH (Aug. 30, 2003), http:// www.counterpunch.org/2003/08/29/who-benefited-from-the-tech-bubble-an-

interview-with-michael-hudson; see also Michael Hudson, From the Bubble Economy to Debt Deflation and Privatization, 64 REAL-WORLD ECON. REV. 21 (2013), available at http://www.paecon.net/PAEReview/issue64/whole64.pdf; Slavoj Žižek, What Is an Authentic Political Event?, NEW STATESMAN (Feb. 12, 2014), http://www.newstatesman.com/culture/2014/02/slavoj-zizek-whatauthentic-political-event ("[F]rom Balkan to Scandinavia, from the US to Israel, from central Africa to India, a new Dark Age is coming, with ethnic and religious passions exploding, and the Enlightenment values receding. These passions were lurking in dark all the time, but what is new now is the outright shamelessness of their display."); Richard D. Wolff, US Political Dysfunction and Capitalism's Withdrawal, E-INTERNATIONAL RELATIONS (Oct. 27, 2013), http://www.e-ir.info/2013/10/27/us-political-dysfunction-and-capitalisms-

withdrawal (describing capitalism's withdrawal from the "old centers" in the United States and elsewhere); Reinert, supra note 27, at 11-15 (adopting the term "post-industrial feudalism"); $c f$. VeBlen, THE PlaCe of SCIENCE IN MODERN CIVILISATION, supra note 29, at 13 (Russell \& Russell, 1961) (1906); DAVID MCNALly, POlitical ECONOMY AND THE RISE OF CAPITALISM: A REINTERPRETATION 3 (1990), available at http://ark.cdlib.org/ark:/13030/ $\mathrm{ft} 367 \mathrm{nb} 2 \mathrm{~h} 4$ (providing a summary of the feudalist economy). A similar claim has already been made specifically with respect to intellectual property by Peter Drahos. DRAHOS WITH BRAITHWAITE, supra note 54; Drahos, supra note 54, at 209-10.

59 JO \& HENRY, supra note 52, at 13 (citing Hyman P. Minsky, Schumpeter and Finance, in MARKET AND INSTITUTIONS IN ECONOMIC DEVELOPMENT: ESSAYS IN HONOR OF SYLOS LABINI (Salvator Biasco et al. eds., 1993).

${ }^{60}$ RAY DiALlo \& AMIT SRIVASTAVA, BRIDGEWATER DAILY ObSERVATIONS, THE MONEY SufFLeR's VIG 1 (2004); cf. Veblen, On the Nature of Capital, supra note 8, at 126-27 ("The dispassionate student of the current business 
imbalance between the expansion of credit versus expansion of productive capacity, as has occurred since the early 1980s. ${ }^{61}$ The same happened in the 1920s during the run-up to the crash of 1929 and the Great Depression. ${ }^{62}$ Yet despite other historical periods in which the FIRE sector was relatively large, the expansion of patent eligibility to things like business methods only occurred with the most recent, post-1970 FIRE sector expansion.

In the patent realm, the so-called post-industrial economy is reflected by increasing patenting in areas of financial and other business methods, information technology and software, and the like. ${ }^{63}$ Such patenting tends to legitimate the activity, and to

traffic, who is not overawed by round numbers, will be more impressed by the ease and simplicity of the maneuvers that lead to large pecuniary results in the higher business finance than by any evidence of pre-eminent sagacity and initiative among the pecuniary magnates [captains of industry]."); see also, e.g., Press Release, Fed. Deposit Ins. Corp., FDIC-Insured Institutions Earned \$42.2 Billion in the Second Quarter of 2013 (Aug. 29, 2013), available at http:// www.fdic.gov/news/news/press/2013/pr13075.html (explaining bank profits rose more than ten times faster than loan growth during one quarter).

61 HÄRING \& DOUGLAS, supra note 56, at 78-80 (citing RICHARD A. WERNER, NEUE WIRTSCHAFTSPOLITIK: WAS EUROPA AUS JAPAN FEHLERN LERNEN KANN (Vahlen 2007)). The recent phenomenon in which "banking, the stock market and the rest of the financial sector" have become decoupled from "the funding of new capital formation [can only] be analyzed by distinguishing between wealth and overhead. And any such discussion rests ultimately on a concept (or set of concepts) dividing the economy's employment, investment and lending into categories of 'productive' and 'unproductive,' or 'earned' or 'unearned' income." HUDSON, supra note 10, at 67.

62 GeOrge Soule, Prosperity DeCADE 280-284 (1947); see also Darren Prince, Essays in Monetary Theory and Policy: On the Nature of Banking (2), NEW ECON. PERSP. (Dec. 23, 2013), http://neweconomicperspectives.org/2013/ 12/essays-monetary-theory-policy-nature-banking-2.html.

${ }^{63}$ See, e.g., Sara Dastgheib-Vinarov, A Higher Nonobvious Standard for Gene Patents: Protecting Biomedical Research from the Big Chill, 4 MARQ. INTELL. PROP. L. REV. 143, 165-68 (2000) (discussing the rise of biotech patenting); U.S. GOV'T ACCOUNTABILITY OFF., ASSESSING FACTORS THAT AFFECT PATENT InFRINGEMENT Litigation COUld HelP IMPROVE PATENT QUALITY, GAO-13-465, 11-13 (2013), available at http://www.gao.gov/assets/ 
displace certain other activities. As discussed below, commentators like John Duffy and Thomas Cotter have argued that these trends should be embraced, if only gradually, when patentability is considered by the judiciary. But such views overlook - or turn a blind eye toward-relationships between invidious pecuniary activity and both economic instability and harm to the general public good. In contrast, those who equate specific aspects of the post-industrial economy with a resurgence of feudalism could further see "patent trolls" (sometimes more benevolently, though not always synonymously, called "non-practicing entities" or "patent monetization entities") as attempting to secure near-feudal rent-extraction rights through patents. ${ }^{64}$ However, troll-like rent-

660/657103.pdf (discussing the rise in software patents, including business method patents); John R. Allison \& Emerson H. Tiller, The Business Method Patent Myth, 18 Berkeley TeCH. L.J. 987, 991 (2003) (citing Michael J. Meurer, Business Method Patents and Patent Floods, 8 WASH. U. J.L. \& POL'Y 309 (2002) and Arti Rai, Addressing the Patent Gold Rush: The Role of Deference to PTO Patent Denials, 2 WASH. U. J.L. \& POL'Y 199, 211 (2000)) (discussing the rise of software-implemented business method patents).

${ }^{64}$ See DRAHOS WITH BRAITHWAITE, supra note 54, at 209; HudSON, supra note 10, at 410 (explaining that the "innovations [of today's financial operators] take the not-so-creative form of predatory destruction of the economy for their own benefit . . . . Industrial technology plays little role in this post-industrial creativity."); see also, e.g., Cheryl Milone, Bad Patents, InTELl. Prop. ALM SUPPLEMENT, Fall 2013, at 27-28 (distinguishing "the so-called patent troll species of NPE, who manipulate the patent litigation process with poor-quality patents to extort settlements from businesses . . . ."); PATENT FREEDOM, INVESTIGATIONS INTO NPE LITIGATION INVOLVING BUSINESS METHOD PATENTS (2013), available at https://www.patentfreedom.com/wp-content/uploads/2013/ 09/NPE-Ligitations-involving-Business-Method-Patents_Sept-4-2013.pdf (patent litigation by non-practicing entities increasingly involves "business method" patents, reaching approximately $41 \%$ in 2011-2012). The present author sometimes jokingly refers to this as the "Spanish method," with patent trolls akin to Spanish conquistadors simply planting a flag to claim vast tracts of land - or in this case, "inventive" subject matter - solely on the basis of a desire for resource (or economic rent) extraction, their "contribution" beginning and ending with the act of planting the flag on territory that already exists. See Austen Zuege, A New Era for Patent-Eligible Subject Matter, InTEll. Prop. TODAY, May 2012, at 21. Data from the firm RPX indicates that approximately $25 \%$ of patent infringement defendants were sued by patent assertion entities in 
seeking patent activity is widespread, extending far beyond merely non-practicing entities. In this sense, asserting claims for "business methods" and the like, in which patent eligibility is questionable, resembles the actions of feudal lords, who owned no means of production but through social privilege extracted rent from those who did. ${ }^{65}$ In much the same way, patents on financial and business activities in an era when credit expansion outpaces increases in productive capacity magnify the imbalances caused by private control of credit creation and access, placing productive industry at a further disadvantage vis-à-vis the financial sector. ${ }^{66}$ The important point here, as elaborated below, is that pressure to expand patent eligibility is linked to the sorts of social contexts Veblen highlighted, in which general welfare is disadvantaged by a prevalence of invidious pecuniary activities over productive ones. Such a Veblenian analysis suggests that recent trends are less about technological innovation bringing forth a truly post-industrial society and more about pecuniary activity parasitically displacing real production in much same the way Veblen warned about so long ago. Yet those economic factors have existed before albeit without patent eligibility expansion. Therefore, we eventually turn to a discussion of how those domestic economic factors coincided with trends in intra-company management, shifts in global trade and industrialization, and a period of judicial expansion of patent eligibility triggered by the rise of (ostensibly) productive technologies like biotechnology and computer software.

recent years. United States Government Accountability Office, supra note 63, at 17 n.36. The term "patent assertion entity" focuses "on entities whose business model solely focuses on asserting typically purchased patents.” $I d$. at 2 n. 6 .

65 MCNALLY, supra note 58.

66 See Wray, supra note 13, at 618 (noting Veblen's observation that the credit economy tends to dominate over the goods economy in the normal course); see also HUDSON, supra note 10, at 156 ("If economic evolution is to reflect the inner logic and requirements of society's technological capabilities, then finance capital must be subordinated to serve the economy, not be permitted to master and stifle it."). 

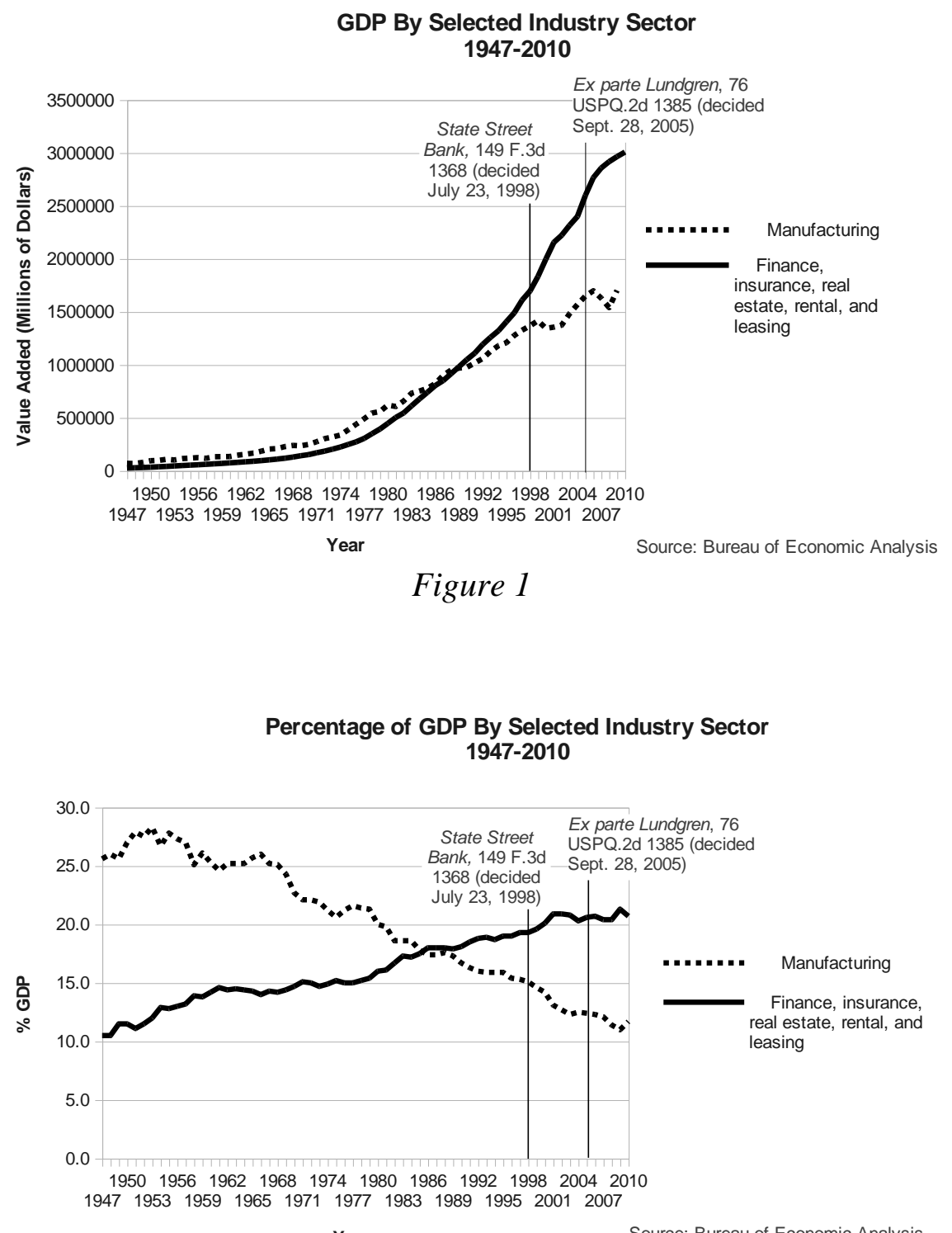

Figure 2 
Percentage of U.S. Corporate Profits By Selected Sector

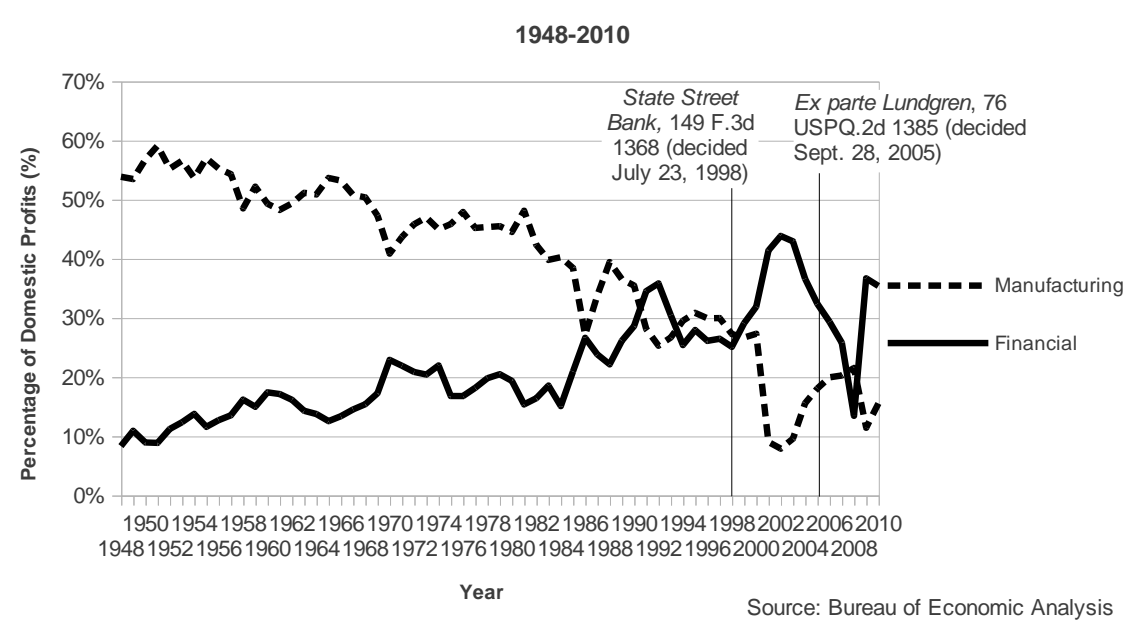

Figure 3

\section{Blurring of Lines}

The relative performance of different economic sectors is only part of the story. There have also been changes within certain sectors that tend to blur the lines between the FIRE and manufacturing sectors. Traditional (real) industry has, in recent times, fitfully moved into financial operations, which began to represent a significant source of profits. ${ }^{67}$ Prominent recent examples are General Electric ("GE") and General Motors

67 DaVid Harvey, The ENIGMa OF CAPITAL AND THE CRISES OF CAPITALISM 23 (2010) ("From the 1980s onwards reports have periodically surfaced suggesting that many large nonfinancial corporations were making more money out of their financial operations than they were out of making things."); see also Michael Hudson, Trade and Payments Theory in a Financialized Economy, MiCHAEL-HudSON.COM (Oct. 26, 2011), http:// michael-hudson.com/2011/10/trade-theory-financialized; JO \& HENRY, supra note 52 , at 27 . 
Acceptance Corporation ("GMAC," now Ally Financial). ${ }^{68 \text { " }[\mathrm{T}] \text { he }}$ the most significant development for GE in the last twenty years has been the expansion of the financial arm of the company - GE Capital, which includes GE Commercial Finance, GE Consumer Finance, GE Equipment Services, GE Insurance, and GE Energy Financial Services. General Electric [in 2010] derive[d] half of its revenue from financial services." 69 "Even corporations that did not set up a financial branch still actively engage in financial operations." $" 70$ Those efforts were significant. Financial trading "manipulations often decide the profits of the entire corporation."71

These economic changes have shifted funding for research and development. Economist Özgür Orhengazi studied the financialization of the U.S. economy since about 1970, and found empirical evidence suggesting that financial activities have displaced research and development within ostensibly nonfinancial companies. $^{72}$ This suggests that in the larger economy, financial

68 Our Company, GECAPITAL.COM, http://www.gecapital.com/en/ourcompany/company-overview.html (last visited Aug. 21, 2013); Our History, ALLY.COM, at http://www.ally.com/about/company-structure/history (last visited Aug. 21, 2013).

69 Pao-yu Ching, Challenging the Conventional Wisdom on the Causes and Cures of the Current Economic Crisis, InST. FOR POL. ECON. J. (July 2010), http://

politicaleconomy.info/index 2.php?option=com_content\&do_pdf=1\&id=46.

${ }^{70} \mathrm{Id}$.

71 Id.; see also Robert R. Locke, Managerialism and the Demise of the Big Three, 51 REAL-WORLD ECON. REV. 28, 38, 43 (2009), available at http:// www.paecon.net/PAEReview/issue51/Locke51.pdf; Hyman P. Minsky, Schumpeter and Finance, in MARKET AND INSTITUTIONS IN ECONOMIC DEVELOPMENT: ESSAYS IN HONOR OF SYLOS LABINI 111-13 (Salvator Biasco et al. eds., 1993).

72 Özgür Orhangazi, Financialisation and Capital Accumulation in the Non-Financial Corporate Sector: A Theoretical and Empirical Investigation on the US Economy: 1973-2003, 32 CAMBRIDGE J. ECON. 863 (2008) (econometric study finding support for the theory that increasing financialization of nonfinancial companies NFCs "impeded real investment by allocating funds away from real investment and by shortening the planning horizons of the 
activities are presently displacing technological ones. This affects a balance between financial companies and ostensibly nonfinancial companies, but also the balance of power within ostensibly nonfinancial companies. After the economy became financialized, "corporations were now run by accountants rather than by engineers . . .."73 Historically, "[e]ngineers on the shop floors and in the manufacturing divisions of $\mathrm{M}$-form [multidivisional] corporations made artifacts. Top management, in which controllers trained in accounting increasingly replaced the engineers, thought about money, that is, about constantly improving return-oninvestment." 74 These changes naturally supported a growth in financial activity. Even when engineers still ran large corporations-like GE's former CEO Jack Welch, a trained chemical engineer - they often displaced technical innovation with an emphasis on financial speculation. ${ }^{75}$ In such a context, the business planning cycle tends to become too short to produce expected monetary returns through investment in research and development effort directed toward technological advancements in making artifacts, in comparison to financial actions like mergers and acquisitions, stock buy-backs, etc. ${ }^{76}$ For those and other

[NFCs.]"); see also ÖZGÜR ORHANGAZI, FINANCIALIZATION AND THE US ECONOMY (Edward Elgar ed. 2008); William Lazonick, The Financialization of the U.S. Corporation: What Has Been Lost, and How It Can Be Regained, 36 SEATTLE U. L. REV. 857, 859-60, 870 (2013); Costas Lapavistas, Theorizing Financialization, 25 WORK, EMPLOYMENT \& SOCIETY 611, 620 (2011).

73 HARVEY, supra note 67.

74 Robert Locke \& J.C. SPENDER, CONFronting MANAGERIALISM: How THE Business ELITE AND THEIR SCHOOLS THREW OUR LIVES OUT OF BALANCE 5 (2011). "[I]ndustrial firms have been turned into essentially financial entities since the 1980s." HUDSON, supra note 10, at 104. "Corporate industry has been taken over so thoroughly by the financial sector that there is little industrial voice left as such." Id. at 65.

75 JefF MAdrick, Age of Greed: The Triumph of FinANCE AND THE DECLINE OF AMERICA, 1970 TO THE PRESENT 185-201 (2012).

76 William Lazonick has suggested, for instance, that pharmaceutical companies have used inflated drug prices to engage in stock buybacks rather than R\&D expenditures. Lazonick, supra note 72, at 896-97; see also Fred 
reasons, financial speculation is being substituted, to some degree, for investment in technology research and development (i.e., investment in the growth of productivity and the "real" economy). Patent attorneys may be aware of this phenomenon, if only obliquely. As the balance of power shifts within a given corporate setting, "inventors" start to come from outside engineering departments and pressure is exerted to have patent applications omit technical details that are often not understood by "inventors" from non-engineering sales and management departments. ${ }^{77}$ All this is in line with Veblen's original theories. He noted the blurring of the relationship "between workmanship and salesmanship," complaining that "much of what appears on the books as production-cost should properly be charged to the production of saleable appearances." $" 78$

\section{Global Implications}

Financial and business endeavors take a privileged position is certain international negotiations. The United States and other North Atlantic states (the "Global North") identify key parts of the

Block, Relational Work and the Law: Recapturing the Legal Realist Critique of Market Fundamentalism, 40 J.L. \& SoC'Y 27, 44-47 (2013); F. Block \& M. Keller, Where Do Innovations Come From? Transformations in the US Economy, 1970-2006, 7 Socio-Economic REV. 459 (2009); Lynne L. Dallas, Short-Termism, the Financial Crisis, and Corporate Governance, 37 J. CORP. L. 265, 279 (2012). IBM, General Electric Co., Microsoft Corp. and other companies have also been identified as promoting similar policies. HUDSON, supra note 10, at 253-54. Of course, patenting is not an exact measure of invention, and innovative activity varies widely across industries.

77 Add to this the growing trend that software companies' "core consumer product is now advertising." Darwin Bond-Graham, Iron Cagebook: The Logical End of Facebook's Patents, COUNTERPUNCH (Dec. 3, 2013), http:// www.counterpunch.org/2013/12/03/iron-cagebook. Bond-Graham actually refers to the "tech industry" to describe the software industry, part of a troubling trend whereby the two terms are treated as synonymous, sometimes even going so far as to cast out things like roads, vehicles, and other artifacts from the scope of the term "technology."

78 THORSTEIN VEBLEN, ABSENTEE OWNERSHIP AND BUSINESS ENTERPRISE IN RECENT TIMES: THE CASE OF AMERICA, 300 (1923). 
FIRE sector together with pharmaceutical, information technology, agro-chemical and entertainment sectors as their core growth engines today, with active efforts to protect comparative advantages in global trade negotiations, such as in the Uruguay Round of the General Agreement on Tariffs and Trade ("GATT"). " "Offshoring" of industrial production since the early 1970s had presented a glaring gap in the traditional economic growth engines tied to industrial production, and treaties such as The Agreement on Trade Related Aspects of Intellectual Property Rights ("TRIPS") were negotiated with an eye toward preventing states of the Global South (i.e., the nations of Africa, Central and Latin America, and most of Asia) from advancing-by leapfrogging otherwise necessary intermediate technological stepping stones - in the Global North's key growth sectors and thereby undermining the illusions of the North Atlantic states' comparative advantages. ${ }^{80}$ This is a function of industrialization

79 Vijay Prashad, The PoOrer Nations: A Possible History of THE Global South 105-11 (2012); see also Valéria Guimarães de Lima e Silva, How to Reshape Treaties without Negotiations: Intellectual Property Enforcement as a Case Study of Global Governance by Stealth, OXFORD Intellectual Property Research Centre 13 (Apr. 16, 2013), http:// denning.law.ox.ac.uk/news/events_files/

Paper_IP_enforcement_VS_NYU_Global_Fellows_Forum_2013.pdf. For a critique of the foundations of the classical, Ricardian theory of comparative advantage, see Reinhard Schumacher, Deconstructing the Theory of Comparative Advantage, 2 WORLD ECON. REV. 83 (2013), available at http:// wer.worldeconomicsassociation.org/article/download/59/41 (pointing out flaws in the theoretical foundations of trade liberalization embodied in WTO processes).

80 PRASHAD, supra note 79 , at 105-11, 180-93; DRAHOS WITH BRAITHWAITE, supra note 54, at 36 (noting the incongruity of including provisions for the protection of creative monopolies that benefit North Atlantic states in treaties ostensibly about global trade liberalization, and that states use patent systems to cloak protectionist policies); Drahos, supra note 54, at 212; see also Michael HARDT \& ANTONIO NEGRI, EMPIRE 284-89 (2000); NOAM ChOMsky, Year 501: The ConQuest Continues 112-17 (1993); cf. The Challenge of the South: The Report of THE South Commission 109-13 (1990). 
occurring beyond the confines of the states in the Global North. The use of patents by governments, and multi-national companies, in promoting trade imbalances is well-explored. ${ }^{81}$ Indeed, an analysis of the TRIPS agreement evidences the strong influence of the Intellectual Property Group ("IPC"), comprised mainly of pharma, software and entertainment industry representatives, on the TRIPS negotiations, which resulted in efforts to enshrine existing trade imbalances against potential disruption by newcomers. ${ }^{82}$ Moreover, recent efforts of U.S. trade negotiators have pushed in the direction of expanding protections on sectors of comparative advantage that center around "business methods," pharma, and the like. ${ }^{83}$ Such efforts are thrown into sometimes

81 Ronaldo Fiani, VEBlen AND PATENTS: AN ASSESSMENT OF THE STRATEGY OF MUlTinAtional ENTERPRises FOR PROTECTING INTELLECTUAL PROPERTY RIGHTS 8-9, available at http://www.academia.edu/3025654/ Veblen_and_Patents_An_assessment_of_the_strategy_of_multinational_enterpri ses_for_protecting_intellectual_property_rights (last visited May 31, 2013) ("for Veblen ... pecuniary motives do not work in the mainstream economics ideal world of perfect competition, but in the real world [of] competition where any expedient provided by social institutions to assure an advantage in competition will be taken.").

${ }^{82}$ Id. at 1-3, 15-17; DRAHOS WITH BRAITHWAITE, supra note 54.

83 Leaked drafts of the Trans-Pacific Partnership (TPP) treaty negotiations by the United States show attempts to expand patent-eligible subject matter to encompass protections for abstract concepts such as business methods, medical/ surgical procedures and the like, though the United States did abandon some hardline positions during negotiations. TRANS-PACIFIC PARTNERSHIP IP GROUP COUNTRY NEGOTIATORS, TRANS-PACIFIC PARTNERSHIP AGREEMENT: Intellectual Property [Rights] ChaPter, ART. QQ.E.1 (Aug. 30, 2013), https://wikileaks.org/tpp/static/pdf/Wikileaks-secret-TPP-treaty-IP-chapter.pdf ("(a) patents shall be available for any new uses or methods of using a known product, (b) a Party may not deny a patent solely on the basis that the product did not result in enhanced efficacy of the known product when the applicant has set forth distinguishing features establishing that the invention is new, involves an inventive step, and is capable of industrial application.") (emphasis added); Trans-Pacific Partnership Intellectual Property Rights ch. 20, art. 8, §1, (Feb. 10, 2011), available at http://keepthewebopen.com/assets/pdfs/ TPP\%20IP\%20Chapter\%20Proposal.pdf; Secret Trans-Pacific Partnership Agreement (TPP), WIKILEAKS (Nov. 13, 2013), https://wikileaks.org/tpp/ 
stark contrast to the sorts of efforts taken by delegations from lesser-developed nations of the Global South, who often seek technology transfer, including "technologies" impacting finance and business management. ${ }^{84}$ It seems clear that one aspect of

pressrelease.html (noting that "[n]umerous key Pacific Rim and nearby nations including Argentina, Ecuador, Colombia, South Korea, Indonesia, the Philippines and, most significantly, Russia and China - have not been involved in the drafting of the [TPP] treaty."); James Love, KEI analysis of Wikileaks leak of TPP IPR text, from August 30, 2013 (Nov. 13, 2013), http:// www.keionline.org/node/1825 ("An interesting example of how the US seeks to change national and global norms are the provisions in the TPP over patents on surgical methods. The WTO permits countries to exclude 'diagnostic, therapeutic and surgical methods for the treatment of humans or animals.' The US wants to flip this provision, so that 'may also exclude from patentability' becomes 'shall make patents available."); TPP Exposed: WikiLeaks Publishes Secret Trade Text to Rewrite Copyright Laws, Limit Internet Freedom DEMOCRACY NOw! (Nov. 14, 2013) (interviewing Lori Wallach), http:// www.democracynow.org/2013/11/14/

tpp_exposed_wikileaks_publishes_secret_trade (Characterizing the TPP IP chapter as being directed to "rent seeking-governments being lobbied by special interests to set up special rules that give them monopolies to charge higher prices."); Risks of the Trans-Pacific Free Trade Agreement for Access to Medicines, Briefing Memo: Analysis of the Leaked U.S. Paper on Eliminating Patent Pre-Grant Opposition, PUBLIC. CiTIZEN (July 7, 2011), https:// www.citizen.org/documents/analysis-of-leaked-US-paper-on-eliminating-

pregrant-opposition.pdf (arguing that U.S. proposals target Indian practices that curtail pharmaceutical patents). Although the leaked drafts still require "industrial applicability" for patent eligibility, the fact that Mexico proposed to explicitly exclude from patentability "the diagrams, plans, rules and methods for carrying out mental processes, playing games or doing business, and mathematical methods as such; software as such; methods to present information as such; and aesthetic creations and artistic or literary works" highlights how little agreement exists on what constitutes "industrial applicability" or "usefulness." As will be clearer in view of the discussion below, the draft terms of the TPP are very anti-Veblenian.

${ }^{84}$ See, e.g., Local Production of Pharmaceuticals and Related Technology Transfer in Developing Countries, UNITED NATIONS CONFERENCE ON TRADE AND DEVELOPMENT (Sept. 19, 2012), http://unctad.org/en/PublicationsLibrary/ diaepcb2011d7_en.pdf; STATEMENT ON THE URUGUAY ROUND: ADOPTED BY THE SOUTH COMmission, AT ITS THIRD MEETING, COCOYOC, MEXICO 10 (1988) (discussing "advances in corporate and financial management technologies"). 
contemporary international trade relations is a belief that the United States can maintain its global position by imposing control on industry located abroad through control of global banking and finance, and ongoing trade negotiations have taken small steps to facilitate and cement such imbalances through patents. In other words, the U.S. strategy is to siphon off surpluses from productive industry located abroad for the benefit of the domestic FIRE sector. $^{85}$ How this strategy benefits the general domestic population, outside the FIRE sector, is scarcely discussed. But, significantly, it departs from the long-standing policies in the United States designed-at least on their face-to promote industry through the patent system for the general public good.

\section{CHANGING JUDICIAL INTERPRETATIONS}

\section{A. Historical Overview}

Standards on patentable subject matter have changed dramatically through recent years without statutory (or constitutional) changes. ${ }^{86}$ The most substantive change in the

85 See BourdiEU, supra note 40, at 226-27; Karl Fitzgerald, Trade Advantage Replaced by Rent Extraction, interview with Michael Hudson (Dec. 17, 2013), http://www.prosper.org.au/2013/12/17/the-road-to-unearned-income ("You have really a financialisation of everybody's income and it's a rent theory of international trade instead of a cost of production theory of international trade competitiveness.").

86 Rajnish Kumar Rai and Srinath Jagannathan, Do Business Method Patents Encourage Innovation, B.C. INTELL. PROP. \& TECH. FORUM 2-3 (2012), available at http://bciptf.org/wp-content/uploads/2012/10/Business-MethodPatents-and-Innovation.pdf (summarizing the historical business method exemption doctrine, followed by the expansion of patent subject matter eligibility in the 1980s and 1990s, culminating in the effective elimination of the business method exemption doctrine). The authors accurately summarize the changes in patentable subject matter in broad strokes, but mistake the holding of the $e$ Bay case as being a ruling on patentable subject matter, when that question was not before the court-mentioned only in passing by Justice Kennedy in a concurrence. It is nonetheless noted that, as summarized by Rai and Jagannathan, the history of judicial expansion of patentable subject matter standards corresponds quite closely with the rise of the neoliberal era and the 
patent laws came in 1952. Although the Leahy-Smith America Invents Act of 2011 did reshape the patent laws, patent-eligible subject matter and the strictures of 35 U.S.C. $\S 101$ were left untouched. ${ }^{87}$ Recent transformations in the analysis of patenteligible subject matters have been almost entirely judiciallydriven - with some administrative influence exerted by patent office bureaucrats. The high water mark for broad patent eligibility was when the Federal Circuit issued the State Street Bank decision in 1998, indicating that business methods could be patentable. ${ }^{88}$ The Supreme Court has weighed in to try to address the issue, but thus far only in limited areas that have barely scratched the surface of the problem. Most emblematic of the ideological struggles among the judiciary is the en banc ruling in the CLS Bank v. Alice case ${ }^{89}$ in which the Federal Circuit, the circuit court with exclusive jurisdiction over appeals involving patent law, was unable to find majority support for a cohesive methodology to analyze patent-

change in the makeup of the U.S economy described above. There are a voluminous number of articles summarizing historical trends in patent-eligible subject matter jurisprudence. See, e.g., John R. Thomas, The Patenting of the Liberal Professions, 40 B.C. L. REV. 1139, 1142-63 (1999); Irwin, supra note 9, at 788-89. However, the role of the 1952 patent law codification has been seen as a driver of patentable subject matter expansion, because the 1952 statutes may have rejected longstanding values underpinning the constitutional, statutory and judicial bases for the patent system. Id. at 782-810.

87 See, e.g., Leahy-Smith America Invents Act, H.R. 1249, 112th Cong. § 18(e) (2011).

88 State Street Bank and Trust Co. v. Signature Financial Group, Inc., 149 F. 3d 1368 (Fed. Cir. 1998). In large part State Street Bank was instrumental in using the language of the 1952 patent law statutory codification, as well as the Chakrabarty and Diehr decisions of the Supreme Court, to justify ignoring the great weight of precedent finding business methods to be nonpatentable subject matter. A Patent Office case that took a similarly broad view of patent eligibility was Ex parte Lundgren, 76 USPQ.2d 1385, (B.P.A.I. 2005) (per curiam).

${ }^{89}$ CLS Bank Int'l v. Alice Corp. Pty. Ltd., 717 F.3d 1269 (Fed. Cir. 2013) (en banc) (per curiam), cert. granted, 82 U.S.L.W. 3131 (U.S. Dec. 6, 2013) (No. 13-298). 
eligible subject matter. ${ }^{90}$ There was, for a long time, judicial consensus that business methods were not patentable. ${ }^{91}$ However, as technologies developed in the Twentieth Century, particularly ones such as biotechnology and computer software, ${ }^{92}$ courts began to expand the scope of patent-eligible subject matter ${ }^{93}$ - some might say haphazardly_and eventually the Federal Circuit unilaterally lifted the long-established ban on patenting business methods. ${ }^{94}$ However, in this era of expanding technological development, the courts continued a rather open-ended expansion of patent eligibility in what might be seen as rather unprincipled ways. Judges opened the doors to new technologies by tweaking the tests applied for subject matter eligibility to accommodate some but not other endeavors, and in some instances lost sight of core policies that seem to have been taken for granted since the first patent statutes were passed in the United States. Not surprising, the judicial expansion of patent eligibility to business methods came precisely at a time when the economic clout of the

${ }^{90}$ Michael S. Borella \& Rory P. Shea, Not Just a Flook?: Consideration of Prior Art When Evaluating Subject Matter Eligibility, INTELL. PROP. TODAY, Sept. 2013, at 19 (summarizing the CLS Bank plurality, concurring, and dissenting opinions).

91 Bilski v. Kappos, 130 S. Ct. 3218, 3232, 3239-46 (2010) (Stevens, J., concurring); Irwin, supra note 86, at 794-95.

92 Sara Dastgheib-Vinarov, A Higher Nonobvious Standard for Gene Patents: Protecting Biomedical Research from the Big Chill, 4 MARQ. INTELL. PROP. L. REV. 143, 165-68 (2000) (providing evidence for the rise of biotech patenting since the 1990s); U.S. Gov. Account. Office, supra note 63, (the number of software patents, including business method patents, has risen dramatically since the early 1990s and surpassed all other types of patents in 2011, though the numbers of nonsoftware patents has also increased over that same time period); Allison \& Tiller, supra note 63, at 991 (noting surge of software-implemented business method patenting from the late 1990s).

93 Diamond v. Diehr, 450 U.S. 175 (1981); Diamond v. Chakrabarty, 447 U.S. 303 (1980); In re Alappat, 33 F.3d 1526 (Fed. Cir. 1994).

94 State Street Bank and Trust Co. v. Signature Financial Group, Inc., 149 F. 3d 1368 (Fed. Cir. 1998); Ex parte Lundgren, 76 USPQ.2d 1385 (B.P.A.I. 2005) (per curiam). 
FIRE sector surpassed that of the manufacturing sector. ${ }^{95}$ These long-term changes eventually divorced the particular patent eligibility tests from whatever widely (if only tacitly) accepted ideological foundations they may have once had, particularly before the 1952 patent law codification. ${ }^{96}$ In order to identify a possible new footing, or even restore the old footing, it will be helpful to first elucidate some of the competing theories.

Numerous articles have attempted to describe historical examples of "business method" patents granted by the USPTO decades or centuries before the modern business method patent debate began. ${ }^{97}$ However, the isolated nature of those exceptions tends to prove the rule that business methods were historically deemed non-patentable subject matter. But the possibility that in isolated incidences USPTO examiners have allowed patents to non-patentable subject matter should be no more controversial than to say that in some instances examiners have improvidently

95 See supra Parts III.B-C.

96 "The [1952] Act did not address the [historical patent eligibility] exclusions - either to codify or to eliminate them." Irwin, supra note 9, at 804; see also Colin P. Marks, Opening the Door to Business Methods: State Street Bank \& Trust Co. v. Signature Financial Group, Inc., 37 Hous. L. REV. 923, 934 (2000) ("The omission of excludable material makes the statute problematic when considering business methods."). In contrast, such exclusions from patent eligibility are explicit under European practice. Convention on the Grant of European Patents art. 52, Oct. 5, 1973, 1065 U.N.T.S. 199, art. 52 ("The following in particular shall not be regarded as inventions . . . schemes, rules and methods for performing mental acts, playing games or doing business, and programs for computers").

97 See, e.g., John R. Thomas, The Post-Industrial Patent System, 10 Fordham InTELL. Prop., Media \& ENT. L.J. 3, 8-27 (1999); James S. Sfekas, Controlling Business Method Patents: How the Japanese Standard for Patenting Software Could Bring Reasonable Limitations to Business Method Patents in the United States, 16 PACIFIC RIM L. \& POL. J. 197, 201-03 (2007); In re Comiskey, 554 F.3d 967, 975-80 (Fed. Cir. 2009); see also Michael Risch, America's First Patents, 64 FLA. L. REV. 1279 (2012) (giving examples of business method patents from the early patent registration system, before pre-grant examination of claims was introduced). 
allowed claims over prior art under the novelty and nonobviousness strictures of 35 U.S.C. $\S \S 102$ and 103 or where enablement was lacking under 35 U.S.C. $\$ 112 .^{98}$

A brief review of the most significant judicial precedents on patent subject matter eligibility is instructive in understanding the framework of current challenges. First, it is noted that exemptions from patent eligibility have long been recognized. A key formulation of the judicially-created exceptions from patent eligibility is that "[p]henomena of nature, though just discovered, mental processes, and abstract intellectual concepts are not patentable, as they are the basic tools of scientific and technological work." $" 99$ A review of selected precedents in this area shows clear limits imposed to restrict the permissible breadth of patents, and the shaping of patent eligibility tests by concern over naked attempts at rent-seeking that lack an associated contribution to a collective pool knowledge of technological proficiency.

\section{B. Relative Consistency in Supreme Court Decisions}

The Supreme Court has been fairly consistent in its views on patent eligibility. The articulation of the standards has evolved and changed, and fell into some disorder in a few early 1980s cases, but something akin to the "preemption" doctrine has been applied since at least the Nineteenth Century. Without wishing to burden

98 In re Miller 418 F.2d 1392 (C.C.P.A. 1969) (Rich, acting C.J.); accord In re Chatfield, 545 F.2d 152, 157 (C.C.P.A. 1976); In re Gulack, 703 F.2d 1381 (Fed. Cir. 1983), described a necessity for a functional relationship between printed matter and a substrate to meet the patentable subject matter requirements of $\S 101$, that did not stop the USTPO from issuing a utility patent for "Religious Soap," which claimed "1. A bar of soap which is embossed with religious markings.” U.S. Patent No. 3,936,384 (filed Jan. 14, 1975).

99 Gottschalk v. Benson, 409 U.S. 63, 67 (1972); see also Mayo Collaborative Servs. v. Prometheus Labs., Inc., 132 S.Ct. 1289, 1293 (2012) (“"[L]aws of nature, natural phenomena, and abstract ideas' are not patentable.") (quoting Diamond v. Diehr, 450 U.S. 175, 185 (1981)). Business method (including medical treatment) and software inventions are generally analyzed as a question of whether they relate to an unpatentable "abstract idea." 
readers with extensive review of precedents, a select number of Supreme Court cases are summarized here. ${ }^{100}$

The 1852 decision in Le Roy v. Tatham, involving a patent to pipe forming machinery, held that "[a] principle, in the abstract, is a fundamental truth; an original cause; a motive; these cannot be patented, as no one can claim in either of them an exclusive right."101 But more importantly, the Court said that "[a] patent is not good for an effect, or the result of a certain process, as that would prohibit all other persons from making the same thing by any means whatsoever." 102 Le Roy established a bedrock concept for all later patent eligibility cases by stating that claims cannot be framed so broadly and abstractly as to merely recite a result. ${ }^{103}$ Similarly, O'Reilly v. Morse struck down a claim that sought to

100 For further summaries, see Thomas F. Morrow, Challenging Patent Subject Matter Eligibility in Patent Litigation, StATE BAR OF TEXAS, $26^{\mathrm{TH}}$ ANNUAl AdVANCED INTELleCtual PROPERTy LAW COURSE 1-12 (Feb. 14-15, 2013), available at http://www.yettercoleman.com/wp-content/uploads/2013/02/ Challenging-Subject-Matter-Eligibility-In-Patent-Litigation.pdf; see also Bilski v. Kappos, 130 S.Ct. 3218, 3239-52 (2009),

10155 U.S. (14 How.) 156, 175 (1852). The syllabus of the Court's opinion restates the claim language at issue: "What we claim as our invention and desire to secure by letters patent is the combination of the following parts, above described, to-wit, the core and bridge, or guide piece, the chamber, and the die, when used to form pipes of metal under heat and pressure in the manner set forth or in any other manner substantially the same." Id. at 171 (emphasis added).

${ }^{102}$ Le Roy, 55 U.S. at 175.

103 This idea of prohibiting claims directed merely to a result or effect is fundamental to later Supreme Court cases, but it is not embodied in the present patent statutes or even guidelines for patent examination promulgated by the USPTO. In contrast, other jurisdictions, such as Europe, explicitly prohibit result-based claiming by way of regulations that require: "As a general rule, claims which attempt to define the invention by a result to be achieved should not be allowed, in particular if they only amount to claiming the underlying technical problem." GUIDELINES FOR EXAMINATION IN THE EUROPEAN PATENT OfFICE pt. F, ch. IV, $\S 4.10$ (rev. ed. 2013). Yet the mere fact that other jurisdictions prohibit this type of claiming is insufficient to explain why such prohibitions are important, which is where a Veblenian perspective is helpful. 
provide monopoly protection over future inventions involving electrical or galvanic current to transmit signals: ${ }^{104}$ "[W]hile he shuts the door against inventions of other persons, the patentee would be able to avail himself of new discoveries in the properties and powers of electro-magnetism which scientific men might bring to light. ... The court is of opinion that the claim is too broad ... " "105 Yet again, the Court in Morse was concerned with claim breadth.

Tilghman v. Proctor dealt with a process claim used to separate compounds from fatty bodies using water at high temperatures and pressures. ${ }^{106}$ The Court found Tilghman's claim patentable, but in reaching that conclusion noted that different processes for achieving the same effect as that claimed by Tilghman were known in the prior art and that Tilghman himself disclosed an unclaimed lower temperature variation capable of achieving the same result. ${ }^{107}$ Importantly, the Court's rationale mirrored that in Le Roy and Morse by finding that the claim language at issue was written narrowly enough to correspond to the actual invention and did not prevent others from utilizing different processes to achieve the same result.

${ }^{104}$ Claim 8 of Morse's patent read: "Eighth. I do not propose to limit myself to the specific machinery or parts of machinery described in the foregoing specifications and claims, the essence of my invention being the use of the motive power of the electric or galvanic current, which I call electro-magnetism, however developed, for making or printing intelligible characters, letters, or signs, at any distances, being a new application of that power, of which I claim to be the first inventor or discoverer." O'Reilly v. Morse, 56 U.S. (15 How.) 62, 86 (1854) (emphasis added).

${ }^{105} \mathrm{Id}$. at 113 .

106 Tilghman v. Proctor, 102 U.S. 707 (1880). There was only one claim in the patent-in-suit: "Having now described the nature of my said invention and the manner of performing the same, I hereby declare that I claim as of my invention the manufacturing of fat acids and glycerine from fatty bodies by the action of water at a high temperature and pressure." Id. at 709.

${ }^{107}$ Id. at $710,720-22$. 
Additionally, in Marchand v. Emken, the Court considered a patent directed to mechanizing a known process for making hydrogen peroxide. ${ }^{108}$

The question, then, seems to be narrowed down to this: Does it constitute invention to stir, by a well-known and simple mechanical device, what had before been stirred by hand? The complainant desired to manufacture in large quantities what had before been produced chiefly in the laboratory. He knew how hydrogen peroxide had been made; every step in the formula was familiar. A mixture that needed stirring, and a vessel provided with a revolving stirrer, were ready at his hand. He put the former into the latter. This was all. The object of agitating the liquid while making hydrogen peroxide, is to keep the barium, which is three times as heavy as water, suspended in the acid, so that its particles may come in contact with the particles of acid. Whether they come in contact while going round, rising, settling, or remaining stationary can make no difference. Divest the case of the air of mystery with which it is environed, and it seems simple enough. The complainant's predecessors knew that to keep the barium up in the solution they must stir it. The complainant knew this. Unlike them, however, he manufactured on a scale large enough to make it essential to employ a power

108 Claim 1 of U.S. Patent No. 273,569 read: "1. The method of making hydrogen peroxide by cooling the acid solution, imparting thereto a continuous movement of rotation, as well in vertical as in horizontal planes-such, for example, as imparted by a revolving screw in a receptacle-and adding to said acid solution the binoxide in small quantities, while maintaining the low temperature and the rotary or eddying movements, substantially as described." U.S. Patent No. 273,569 (filed Aug. 2, 1882); Marchand v. Emken, 132 U.S. 195, 198 (1889). 
shaft. $^{109}$

The Court answered the patentability question in the negative:

There is here no sufficient foundation upon which to rest a claim which, if construed as broadly as the complainant insists it should be, practically makes all pay tribute who stir the mixture in question by machinery, and by hand also, provided substantially the same movement can be produced by hand-stirring, and this seems to be a disputed question upon the proof. The complainant's claim to be enrolled upon the list of inventors is based upon propositions too theoretical and visionary for acceptance. ${ }^{110}$

Without discussion, the Court held that on the "disputed question upon the proof," the mixture could be stirred by hand in the same manner as with machinery. ${ }^{111}$ In essence, the claim was struck down because it would have given too broad a patent monopoly, one not tied to an inventive contribution to an underlying technical problem. The Court found it impermissible to patent the use of conventional machinery for large-scale

${ }^{109} I d$. at 199 (emphasis added).

${ }^{110}$ Id at 200; see also In re Rundell, 48 F.2d 958 (C.C.P.A. 1931); cf. CyberSource Corp. v. Retail Decisions, Inc., 654 F.3d 1366, 1375 (Fed. Cir. 2011) (explaining that the incidental use of a computer to perform a mental process does not impose a sufficiently meaningful limit on claim scope to confer patent eligibility); SiRF Tech., Inc. v. Int'l Trade Comm'n, 601 F.3d 1319, 1333 (Fed. Cir. 2010) ("In order for the addition of a machine to impose a meaningful limit on the scope of a claim [to render the claim patent-eligible], it must play a significant part in permitting the claimed method to be performed, rather than function solely as an obvious mechanism for permitting a solution to be achieved more quickly, i.e., through the utilization of a computer for performing calculations.").

${ }^{111}$ Marchand, 132 U.S. at 200 (affirming the circuit court's decision on the factual question). 
commercialization of a known process, while still accepting that large-scale commercialization of the particular process had not previously been accomplished. But the Court's rationale goes further to say that the abstract concept ("theoretical and visionary"112 ideas) that there are economies of scale associated with mechanization within the field of endeavor at hand (making hydrogen peroxide) is ineligible for patent protection.

Turning to relatively more modern cases, Funk Brothers Seed Co. v. Kalo Inoculant Co. reasoned that devising saleable packaging - in that case for "the aggregation of select strains of . . . several species" of inoculants — did not confer patent eligibility. ${ }^{113}$ The emphasis on "application of the law of nature to a new and useful end" for patent eligibility resembles a requirement for an economically productive technical contribution, ${ }^{114}$ a concept discussed in detail below. ${ }^{115}$ The Funk Brothers opinion took a very strict view of what constitutes mere saleable packaging because the claimed invention sought to reduce a mutually inhibitive effect that different strains root nodule bacteria used as inoculants were previously thought to exert on each other. ${ }^{116}$ Though given a fair reading, there may be some merit to the argument that an aggregation of inoculants provided no new productive benefit but only a pecuniary benefit in how inoculants were sold to end users. Although unfortunately not discussed in the Funk Brothers opinion, it is significant that the claims at issue used a negative limitation to provide preemptive coverage of a result without limits as to the particular combinations of non-inhibitive strains actually discovered (i.e., the essential element of the inventive solution to the underlying technical problem). Claim 4 was illustrative: "An inoculant for leguminous plants comprising a

112 Id.

113 Funk Bros. Seed Co. v. Kalo Inoculant Co., 333 U. S. 127, 131 (1948).

${ }^{114} I d$. at 130.

115 See infra Part IV.

116 Funk Bros., 333 U.S. at 130. 
plurality of selected mutually non-inhibitive strains of different species of bacteria of the genus Rhizobium, said strains being unaffected by each other in respect to their ability to fix nitrogen in the leguminous plant for which they are specific." 117 In concurrence, Justice Frankfurter helpfully suggested that the patentee's problem was the failure to claim particular combinations of bacterial strains that produced the non-inhibitive effect and that reciting the particular strains of bacteria might have made a claim patent-eligible. ${ }^{118}$ The Funk Brothers opinion did not articulate a definitive standard for establishing patent eligibility, but it is an important case in highlighting how aggressively broad claiming is a problem that the Supreme Court has traditionally chosen to address as a question of patent subject matter eligibility. Although frequently viewed by patent practitioners as overly restrictive, the Funk Brothers opinion was a piece with long-standing Supreme Court precedent. ${ }^{119}$

In Gottshalk v. Benson, Justice Douglas analyzed claims to a method for converting binary-coded decimal (BCD) numerals into pure binary numerals on a general purpose digital computer in his famous "nutshell" comment:

It is conceded that one may not patent an idea. But in practical effect that would be the result if the formula for converting BCD numerals to pure binary numerals were patented in this case. The mathematical formula involved here has no substantial practical application except in connection with a digital computer, which means that if the judgment below is affirmed, the patent would wholly pre-empt the mathematical formula

${ }^{117}$ Id. at 128 n. 1 .

${ }^{118} I d$. at $133-34$.

119 See Tilghman v. Proctor, 102 U.S. 707, 710 (1880); O'Reilly v. Morse, 56 U.S. (15 How.) 62, 113 (1854); Le Roy v. Tatham, 55 U.S. (14 How.) 156, 173 (1852). 
and in practical effect would be a patent of the algorithm itself. ${ }^{120}$

This "nutshell" announced the "preemption" doctrine as a limit on patent eligibility, encapsulating the rationale behind many prior Supreme Court decisions. This limit on patent eligibility prevents private monopolies over the common stock of ideas and scientific concepts needed for any use of technical proficiency for public benefit, that is to say, for use in any technical application. Yet the articulation of the "nutshell" analysis in Benson is confusing, in part because the remainder of the opinion sets off on an entirely different analysis, and, frankly, is rather unconvincing in how it

${ }^{120}$ Gottschalk v. Benson, 409 U.S. 63, 71-72 (1972). Although, curiously, the claims at issue were not reproduced in the Benson opinion, they are found in a lower court opinion: " 8 . The method of converting signals from binary coded decimal form into binary which comprises the steps of (1) storing the binary coded decimal signals in a reentrant shift register, (2) shifting the signals to the right by at least three places, until there is a binary ' 1 ' in the second position of said register, (3) masking out said binary ' 1 ' in said second position of said register, (4) adding a binary ' 1 ' to the first position of said register, (5) shifting the signals to the left by two positions, (6) adding a ' 1 ' to said first position, and (7) shifting the signals to the right by at least three positions in preparation for a succeeding binary " 1 " in the second position of said register. . . 13. A data processing method for converting binary coded decimal number representations into binary number representations comprising the steps of (1) testing each binary digit position i, beginning with the least significant binary digit position, of the most significant decimal digit representation for a binary ' 0 ' or a binary ' 1 '; (2) if a binary ' 0 ' is detected, repeating step (1) for the next least significant binary digit position of said most significant decimal digit representation; (3) if a binary ' 1 ' is detected, adding a binary ' 1 ' at the $(i+1)$ th and $(i+3)$ th least significant binary digit positions of the next lesser significant decimal digit representation, and repeating step (1) for the next least significant binary digit position of said most significant decimal digit representation; (4) upon exhausting the binary digit positions of said most significant decimal digit representation, repeating steps (1) through (3) for the next lesser significant decimal digit representation as modified by the previous execution of steps (1) through (3); and (5) repeating steps (1) through (4) until the second least significant decimal digit representation has been so processed." In re Benson, 441 F.2d 682, 683-84 (C.C.P.A. 1971) (reproducing claims 8 and 13 of Application Ser. No. 315,050), rev'd, 409 U.S. 63 (1972). 
asks from a policy perspective whether computer programs constitute patent-eligible subject matter. ${ }^{121}$ However, the core of the "nutshell" analysis regarding preemption becomes clearer if viewed as barring patent eligibility for the mere recitation of a computer to capture a portion of the saleable market for the underlying algorithm (i.e., the abstract mathematical concept), which is significant for the present patent eligibility theory.

Parker v. Flook found that a claim for which the asserted point of novelty lay with a mathematical algorithm was not patenteligible. ${ }^{122}$ Consistent with Benson, the Court held that "[e]ven though a phenomenon of nature or mathematical formula may be well known, an inventive application of the principle may be patented. Conversely, the discovery of such a phenomenon cannot support a patent unless there is some other inventive concept in its application." "123 In short, Flook held that adding a non-inventive recitation to restrict a claim to a particular industry's usage of an abstract idea was not sufficient to confer patent-eligibility. Flook reaffirmed the principle that abstract ideas and other basic tools of scientific and technological work are treated as part of the prior art. ${ }^{124}$ Although more detail was added to the rationale of Benson, vague reference to the need for "applications" of abstract concepts to confer patent eligibility makes it difficult to consistently apply the Flook decision to other sets of facts.

121 An interesting comment here comes from Donald S. Chisum, who has noted that the context for the Benson case was that vested interests in the computer hardware industry did not significantly profit from software at the time and sought to minimize disruptions from small newcomers in the software market by minimizing protection of software. Donald S. Chisum, Patenting Intangible Methods: Revisiting Benson (1972) After Bilski (2010), 27 SANTA Clara Computer \& High TECH. L.J. 445, 446-49 (2011). The complaint Chisum raises here is whether patent standards cater to vested interests, and he sees Benson as exacerbating that problem. Id.

122 Parker v. Flook, 437 U.S. 584, 595 (1978).

123 Id. at 594.

124 Id. at 591-92 (citing O'Reilly v. Morse, 56 U.S. (15 How.) 62 (1854); Neilson v. Harford, Webster's Patent Cases 295, 371 (1844). 
Diamond v. Diehr was the third Supreme Court case to deal with patent eligibility of software and associated methods and the first to find a claim patent-eligible. ${ }^{125}$ Although no prior decisions were explicitly overruled, it is clear that the Diehr decision broke with the rationale underlying Benson and Flook. ${ }^{126}$ Justice Breyer later noted the incongruity of Diehr and Flook during oral arguments for a subsequent case. ${ }^{127}$ By stating - contrary to the approach of Flook - that patent eligibility should not be assessed at the point of novelty, Diehr found a patent-eligible invention in a combination of elements. ${ }^{128}$ Yet examination of the purported inventive "combination" at issue in Diehr does not reveal any meaningful inventive contribution other than recitations that preempt using the Arrhenius equation within an economic market for curing rubber using automated machines of some sort. This is a situation nearly identical to that in the Marchand v. Emken case, yet the Court in Diehr reached an opposite result on patentability. ${ }^{129}$ As discussed below, it is possible to think of the

${ }^{125}$ Diamond v. Diehr, 450 U.S. 175 (1981).

126 The number of justices dissenting from the Diehr majority opinion evidence the abrupt shift from Benson and Flook, to some extent. "Confusion originated in the inherent conflict between the Diamond v. Diehr and the Parker v. Flook Supreme Court decisions, since the majority decisions in these two cases appear to contradict each other in fundamental ways (see the Stevens dissent in Diamond v. Diehr for a discussion of this conflict). What was clear was that the patentability of a software related invention depended heavily on the claims crafted by the patent attorney." Daniel A. Tysver, History of Software Patents, from Benson, Flook and Diehr to Bilski and Mayo v. Prometheus, BITLAW, http://www.bitlaw.com/software-patent/history.html (last visited Mar. 20, 2014) (internal hyperlinks omitted). It should also be noted that Justice Rehnquist, who wrote the Diehr opinion, dissented from the Flook decision.

127 Transcript of Oral Argument at 14, Mayo Collaborative Servs. v. Prometheus Labs., Inc., 132 S.Ct. 1289 (2012), available at http:// patentlyo.com/media/docs/2011/12/10-1150.pdf (Breyer, J.) ("If you look at the Court's cases, they seem to say Flook, one thing, and Diehr, another thing.").

${ }^{128}$ Diehr, 450 U.S. 175 at 188,190-92.

129 Marchand v. Emken, 132 U.S. 195 (1889) (finding the claim unpatentable). 
addition of only generic "machine automation" recitations to an underlying abstract concept as merely adding another abstract concept to the claim, namely the fundamentally social notion of replacing workers with machines. In this respect, Diehr provided the impetus for a surge in highly formalistic end-runs around the patent-eligibility question through careful claim drafting that adds cursory reference to a machine but does not recite the essential elements of the solution to the underlying technical problem. ${ }^{130}$ Diehr starts to substitute a first-mover approach to patentability, in that any person first to recognize that an abstract concept has saleable economic value in a particular market can obtain a patent by restricting the scope of the patent monopoly to that particular area of economic activity, without more. ${ }^{131}$

Diamond v. Chakrabarty was the first Supreme Court case to deal with patent eligibility for biotechnology inventions. ${ }^{132}$ The Court asked whether the claimed microorganism constituted a "manufacture" or "composition of matter" within the meaning of 35 U.S.C. $\S 101$; it held that the artificially synthesized microorganism being claimed was "the result of human ingenuity and research" and was patent-eligible. ${ }^{133}$ This seemed to reach a proper result, in that productive activities creating new synthetic organisms was found to be patentable, but the Chakrabarty opinion offered a somewhat skewed reading of legislative history; it suggested that there were few, if any, limits on patent eligibility-

130 Such an approach broke with Supreme Court precedent. See, e.g., Le Roy v. Tatham, 55 U.S. (14 How.) 156, 174-75 (1852); Marchand v. Emken, 132 U.S. 195, 200 (1889).

131 See generally Irwin, supra note 9, at 814-15 (discussing a shift in underlying rationales for patentability standards).

132 Diamond v. Chakrabarty, 447 U.S. 303 (1980).

133 Id. at 313. Though Chakrabarty seemed to reach the correct result, the rationale that "Congress intended statutory subject matter to include anything under the sun made by man" aligns more closely with the problematic aspects of Diehr. Id. at 309 (quoting S. REP. No. 82-1979 at 5 (1952); H.R. REP. No. 821923 at $6(1952))$. 
something that colored many later judicial decisions, ${ }^{134}$ particularly in lower courts.

Decades later, the Court decided Association for Molecular Pathology v. Myriad Genetics, which similarly found that synthetic material such as complementary DNA (cDNA) was patenteligible. ${ }^{135}$ However, the Myriad Court found that claims directed to isolated segments of naturally occurring DNA sequences were not patent-eligible. ${ }^{136}$ "Myriad's principal contribution was uncovering the precise location and genetic sequence of the BRCA1 and BRCA2 genes within chromosomes 17 and 13.",137 The Court found that unlike the inventor in Chakrabarty, "Myriad did not create anything. To be sure, it found an important and useful gene, but separating that gene from its surrounding genetic material is not an act of invention." "138 Rebuffing a sweat-of-thebrow labor theory, the Court critically held that "extensive effort alone is insufficient" to confer patent eligibility. ${ }^{139}$ The overly broad claim at issue reflected only effort (and money) invested in the discovery of information necessary for further development of saleable products and services in the associated field, rather than the contribution of a solution to an underlying technical problem.

Bilski v. Kappos was the first Supreme Court decision to directly assess the patent eligibility of what was unequivocally acknowledged as a "business method."140 Specifically, Bilski

134 Bilski v. Kappos, 130 S.Ct. 3218, 3248-50 (2009) (Stevens, J., concurring).

135 Ass'n for Molecular Pathology v. Myriad Genetics, Inc., 133 S.Ct. 2107, 2119 (2013).

136 Id. at 2120.

137 Id. at 2216.

138 Id. at 2217. The Court noted that "Myriad's claims . . . [do not] rely in any way on the chemical changes that result from the isolation of a particular section of DNA." Id. at 2118.

139 Id. at 2118.

140 Bilski v. Kappos, 130 S.Ct. 3218, 3223 (2010). 
claimed a method of hedging losses in commodities trading. ${ }^{141}$ The method claims in Bilski did not require a computer or other machine or apparatus. The Court held that the claims were not patent-eligible because they were drawn to "an unpatentable abstract idea, just like the algorithms at issue in Benson and Flook."142 The most significant holding in Bilski was in overturning the lower court's finding that the "machine-ortransformation" test was the exclusive test for patent eligibility. Instead, the Court held that: "[T] is a useful and important clue, an investigative tool, for determining whether some claimed inventions are processes under $\S 101$. The machine-or-transformation test is not the sole test for deciding whether an invention is a patent-eligible "process.",143 The Court nonetheless avoided any meaningful discussion of constitutional limits on patent eligibility. Like many other Supreme Court cases on patent eligibility decided after 1980, Bilski focuses rather narrowly on statutory interpretation of 35 U.S.C. $\S 101$ and omits much of the constitutional and policy-based analysis of earlier cases. The major failing of the Bilski opinion itself is that it tends to treat Benson, Flook, and Diehr as if those prior decisions took a consistent approach to the question of patent eligibility, when they clearly do not. The majority opinion made no attempt to reconcile the inconsistency in those precedents. To draw a football analogy, the majority's Bilski decision punted the ball down the field, thus putting off until a later date the difficult task of

141 Claim 1 read “(a) initiating a series of transactions between said commodity provider and consumers of said commodity wherein said consumers purchase said commodity at a fixed rate based upon historical averages, said fixed rate corresponding to a risk position of said consumers; (b) identifying market participants for said commodity having a counter-risk position to said consumers; and (c) initiating a series of transactions between said commodity provider and said market participants at a second fixed rate such that said series of market participant transactions balances the risk position of said series of consumer transactions." Id. at 3223-24.

142 Id. at 3231 .

${ }^{143}$ Id. at 3227. 
harmonizing precedent. In his final decision before retirement, Justice Stevens wrote a concurrence (joined by Justices Ginsburg, Breyer, and Sotomayor) indicating that he "would restore patent law to its historical and constitutional moorings." 144 Stevens noted that business methods were categorically excluded from patent eligibility for centuries, and it was only in the 1990s that the Federal Circuit began to call that categorical exclusion into question. $^{145}$

Mayo Collaborative Services v. Prometheus Laboratories, Inc. made "preemption" a primary criterion for patent-eligible subject matter under $\S 101 .{ }^{146}$ Application of the machine-ortransformation test for patentability, still used extensively by lower courts, was relegated to a decidedly secondary position in the analysis, at best. ${ }^{147}$ According to the majority in Mayo, "a process that focuses upon the use of a natural law [must] also contain other elements or a combination of elements, sometimes referred to as an 'inventive concept,' sufficient to ensure that the patent in practice amounts to significantly more than a patent upon the natural law itself." "148 The mere act of "picking out the relevant audience"which essentially involves identifying the saleable market for an abstract idea, law of nature, or natural phenomenon - is not enough to confer patent eligibility. ${ }^{149}$ From a Veblenian perspective, this can be seen as a requirement that patent claims be directed to a contribution to the common stock of technical proficiency, rather than merely staking a pecuniary claim to concepts that are fundamental to any work in a given field. There was, indeed, a

${ }^{144} I d$. at 3232 (Stevens, J., concurring).

${ }^{145} I d$. at 3232, 3239-50. Justice Stevens' concurrence is well worth reading on its own. Much of the discussion that follows in this article is along the lines of the argument laid out in Justice Stevens' Bilski concurrence.

146 Mayo Collaborative Servs. v. Prometheus Labs., Inc., 132 S.Ct. 1289 (2012); see also Zuege, supra note 64, at 19.

${ }^{147}$ Mayo, 132 S.Ct. at $1302-04$.

${ }^{148}$ Id. at 1294 .

${ }^{149} I d$. at 1299. 
cursory reference to this concept in the Mayo opinion, which stated that rent-seeking through patenting can be problematic, ${ }^{150}$ and that there is a "two-edged sword" in the encouragement of invention through monopoly grants that requires a careful balance. ${ }^{151}$ Mayo was a re-affirmance of the rationale of the Flook line of cases and various Nineteenth Century Supreme Court precedents that dealt with the question of patent eligibility in terms of whether a patentee (or patent applicant) is overreaching by presenting preemptive patent claims that lack the inventive contribution required as part of the quid pro quo of a patent monopoly. Yet Mayo hardly settled the debate, and, despite some helpful but tentative and brief asides, still fell short of clearly articulating a general theory as to why the concept of "preemption" really matters, such that judges, patent office staff, and patentees can have a shared sense of purpose in applying a patent eligibility standard-however formulated.

\section{Conflicting Views on the Federal Circuit}

The Federal Circuit remains the locus for the patentable subject matter debate, with a "deep underlying philosophical divide" regarding the correct approach for patent eligibility analysis. ${ }^{152}$ Yet, there is a growing consensus on the still-divided Federal Circuit that something close to a technological arts test should be applied. ${ }^{153}$ For instance, certain current and recently departed

150 Id. at 1301-02 (quoting W. LANDES \& R. Posner, THE ECONOMIC STRUCTURE OF INTELLECTUAL PROPERTY LAW 305-306 (2003)).

${ }^{151}$ Mayo, 132 S.Ct. at 1305.

152 Dina Roumiantseva, The Eye of the Storm: Software Patents and The Abstract Idea Doctrine in CLS Bank v. Alice, 28 BERKELEY TECH. L.J. 569, 577-78 (2013).

153 For comments on the divide among current Federal Circuit judges on this issue, see Bruce Sunstein, New Obstacles Are Raised to Protecting Computer-Related Inventions, INTELL. PROP. TODAY, Dec. 2013, at 27; Roumiantseva, supra note 153, at 577-88. For summaries of technological arts tests applied in select other countries, see, e.g., Jay Erstling et al., Usefulness Varies by Country: The Utility Requirement of Patent Law in the United States, 
Federal Circuit judges have fairly consistently ruled in a variety of cases that to satisfy the utility requirement of 35 U.S.C. $\S 101$ there must be a close nexus between a recited computer and the nature of the invention. Although those judges stop short of stating a technological arts test, their opinions seem to reject the notion that business and financial methods can ever be patent-eligible, such as by finding that such methods could have been performed mentally or finding the cursory recitation of a computer (or other concrete object) insufficient to satisfy $\S 101$. These judges have expended considerable effort across numerous opinions to try to elucidate in a meaningful way what level of detail is required to reduce the level of abstraction of a claim sufficient for patent eligibility. ${ }^{154}$

Europe and Canada, 3 CYBARIS 1 (2012), http://web.wmitchell.edu/cybaris/wpcontent/uploads/2012/06/Erstling-Salmela-Woo.pdf. In Europe, business methods and software per se are categorically excluded from patent eligibility. Convention on the Grant of European Patents art. 52, Oct. 5, 1973, 13 I.L.M. 268 ("EPC") ("The following in particular shall not be regarded as inventions . . . schemes, rules and methods for performing mental acts, playing games or doing business, and programs for computers.").

${ }^{154}$ E.g., Accenture Global Servs. v. Guidewire Software, Inc., 728 F.3d 1336 (Fed. Cir. 2013) (Lourie, J.); Classen Immunotherapies, Inc. v. Biogen IDEC, 659 F.3d 1057, 1075-81 (Fed. Cir. 2011) (Moore, J., dissenting); Alexsam, Inc. v. IDT Corp., 715 F.3d 1336, 1349-50 (Fed. Cir. 2013) (Dyk, J. dissenting); CLS Bank Int'l v. Alice Corp. Pty. Ltd., 717 F.3d 1269 (Fed. Cir. 2013) (en banc) (per curiam) (Lourie, J., concurring), cert. granted, 82 U.S.L.W. 3131 (U.S. Dec. 6, 2013) (No. 13-298); Bancorp Servs., L.L.C. v. Sun Life Assurance Co. of Canada, 687 F.3d 1266 (Fed. Cir. 2012) (Lourie, J.); MySpace, Inc. v. GraphOn Corp., 672 F 3d 1250 (Fed. Cir. 2012) (Mayer, J., dissenting); Dealertrack, Inc. v. Huber, 674 F.3d 1315 (Fed. Cir. 2012); Fort Props., Inc. v. Am. Master Lease LLC, 671 F.3d 1317 (Fed. Cir. 2012); CyberSource Corp. v. Retail Decisions, Inc., 654 F.3d 1366 (Fed. Cir. 2011) (Dyk, J.); SiRF Tech., Inc. v. Int'l Trade Comm'n., 601 F.3d 1319 (Fed. Cir. 2010) (Dyk, J.); In re Bilski, 545 F.3d at 998 (Mayer, J., dissenting); In re Comiskey, 554 F.3d 967 (Fed. Cir. 2009) (Dyk, J.) (revised opinion); In re Bilski, 545 F.3d 943 (Fed. Cir. 2008) (en banc) (Dyk, J., with Linn, J., concurring). It is speculative to assess how Federal Circuit judges feel about this issue, generally, and some judges may have changed their views over time. However, some Federal Circuit judges, like Judge Dyk and current Chief Judge Rader, have clearly come out on opposite sides of the debate. There have been 
Cases from this faction of the Federal Circuit seem cognizant that the Constitution may impose limits on what the patent statutes can make patent-eligible and hint at some sort of technological-artslike test. ${ }^{155}$ While this first faction has tried to bring clarity to the patent subject matter eligibility debate, they have yet to articulate a sufficiently clear theory or test to establish consensus. The discussion that follows will illustrate how a Veblenian perspective might strengthen and clarify an underlying theory for such tests, consistent with various Supreme Court opinions - and particularly Justice Stevens' concurrence in Bilski.

Another faction of Federal Circuit judges have been firmly opposed to patent eligibility challenges and insist that patent eligibility challenges are really questions of claim novelty/obviousness, definiteness, and/or enablement and as such can or should be addressed under other statutory sections of the patent laws. ${ }^{156}$ Led by Chief Judge Rader, the most vociferous

attempts to assign Federal Circuit Judges to opposing camps, though. See Roumiantseva, supra note 153, at 578, 581-82 (placing Judges Rader, Newman, Plager, and O'Malley in the broad "coarse filter" camp/faction and Judges Dyk, Prost, Moore, Schall, and Bryson in the "limiting test" camp/faction); Sunstein, supra note 154 , at 27 . More recently appointed Judges like Renya, Wallach, and Taranto seem to fall into the "limiting test" camp/faction. See CLS Bank Int'l, 717 F.3d 1269 (Lourie, J., concurring); Bancorp Servs., 687 F.3d 1266; Accenture Global Servs., 728 F.3d 1336; Smartgene, Inc. v. Advanced Biological Labs, SA, No. 2013-1186, 2014 WL259824 (Fed. Cir. Jan. 24, 2014) (Taranto, J.) (nonprecedential).

155 The rationales in opinions from these judges align with Supreme Court cases like Benson and Flook.

156 E.g., Classen Immunotherapies, Inc. v. Biogen IDEC, 659 F.3d 1057, 1075 (Fed. Cir. 2011) (Newman, J.); Research Corp. Techs. v. Microsoft Corp., 627 F.3d 859, 869 (Fed. Cir. 2010) ("[S]ubject matter might . . . be so conceptual that the written description does not enable a person of ordinary skill in the art to replicate the process.") (Rader, C.J.); Bilski, 545 F.3d at 977-94 (Newman, J., dissenting); Ultramercial, Inc. v. Hulu, LLC, 722 F.3d 1335, 1342,1345-48 (Fed. Cir. 2013) (Rader, J.) (emphasizing other statutory limits for patentability and attempting to diminish the significance of the "preemption" doctrine); Dealertrack, 674 F.3d at 1335 (Plager, J., dissenting-in-part, concurring-in-part); CLS Bank Int'l., 717 F.3d at 1292-1336 (dissenting and 
Federal Circuit judge on this point, the opinions of this faction reflect a view that patentable subject matter "may include even methods of doing business." 157 For instance, these judges repeatedly reject or ignore calls to specify the level of complexity of computer programming necessary to no longer be "abstract" under $\S 101 .{ }^{158}$ These judges also consistently frame issues under the rubric of the sweeping scope of $\S 101$, and the definition of "process" in $\S 100$, without reference to limiting language of the Patent \& Copyright Clause of the Constitution or early Supreme Court cases and therefore without recognition of the ways that the language from the 1952 patent law revisions (and later legislative amendments) may have departed from constitutional limits. ${ }^{159}$ They conclude that the statutory threshold is very low, a "coarse filter," 160 and they put few teeth into the "preemption" doctrine. ${ }^{161}$ There are numerous problems with the second faction's view that concerns raised about patent subject matter eligibility should not be addressed under $\S 101$ but should instead be policed elsewhere, such as under 35 U.S.C. $\S \S 102,103$ and 112. For one, this view renders $\S 101$ somewhat dead letter, in a way that may simplify judicial decision-making but only at the expense of forcing

dissenting-in-part opinions, and additional reflections); In re Schrader, 22 F.3d 290 (Fed. Cir. 1994) (Plager, J.).

157 Ultramercial, 722 F.3d at 1342 (citation omitted); see also Bilski, 130 S.Ct. at 3223-24 (2010) (reciting claim 1).

${ }^{158}$ Ultramercial, 722 F.3d at 1353 ("[T]his court does not define the level of programming complexity required before a computer-implemented method can be patent-eligible.").

159 The rationales in opinions from these judges tend to align with the Supreme Court's opinion in Diehr more so than in Benson or Flook, for instance. See, e.g., Arrhythmia Research Tech., Inc. v. Corazonix Corp., 958 F.2d 1053, 1066 (Fed. Cir. 1992 (Rader, J., concurring) (arguing that Diehr limited Benson and supposedly "refocused" the patentability analysis on the statutory language rather than "vague" judicial exclusions).

160 Classen Immunotherapies, Inc., 659 F.3d at 1066; Research Corp. Techs., Inc., 627 F.3d at 869.

${ }^{161}$ E.g., Ultramercial, Inc., 722 F.3d at 1345-46 (Rader, J.). 
accused infringers and patent examiners to waste efforts on more burdensome investigations to uncover prior art, etc. This position takes an unequal view of the burdens associated with the arguments under different statutory sections and expresses concern for the amount of effort involved only when that effort is expended by judges - anathema to a legal realist analysis. The refusal to consider multiple bases for unpatentability is also not justified in any meaningful way. For instance, patent litigators rarely believe that a validity challenge under $\S 112$ has a great chance of success, yet panels of the Federal Circuit seem to imply that making a $\S 112$ invalidity argument is a preferred approach. ${ }^{162}$ There is a large disconnect in that regard. Moreover, indefiniteness issues surrounding functional claiming at the point of novelty (in claims without means-plus-function or step-plus-function recitations) are rarely relied upon by patent examiners, and the topic receives no treatment in the Manual of Patent Examining Procedure. ${ }^{163}$ This second faction of Federal Circuit judges is perhaps the most resistant to clarity in the area of patent eligibility, but a Veblenian perspective might provide them with a new way to look at the underlying issues and perhaps find common ground with the other faction.

Many of the changing interpretations can be viewed as reflecting changing economic ideologies held by the judiciary. ${ }^{164}$

162 The standard for definiteness under 35 U.S.C. $\S 112$ is currently awaiting Supreme Court review. Biosig Instruments, Inc. v. Nautilus, Inc., 715 F.3d 891 (Fed. Cir. 2013), cert. granted, 134 S. Ct. 896 (U.S. Jan, 10, 2014) (No. 13-339).

163 Contra, e.g., Ex parte Miyazaki, 89 USPQ.2d 1207 (B.P.A.I. 2008). However, President Obama recently initiated a training program around the issue of functional claiming. FACT SHEET-Executive Actions: Answering the President's Call to Strengthen Our Patent System and Foster Innovation, WHITEHOUSE (Feb. 20, 2014), http://www.whitehouse.gov/the-press-office/ 2014/02/20/fact-sheet-executive-actions-answering-president-s-call-strengthenour-p.

164 Similarly, Robert Post suggested that variations in patent allowance rates after the Civil War reflected not changes in inventive activity but primarily 
For instance, Federal Circuit opinions often argue (without much empirical support) in terms of the economic effect of various patent policy decisions. ${ }^{165}$ In this context, questions regarding who should benefit from access to creative monopolies as secured by patents are highly relevant. If the major basis of the economy in the United States moves away from productive technologymachines, electronics, chemicals and the like-then it seems inevitable that patents restricted to productive technology would experience a corresponding decline in significance. But this raises the question, too, of whether economic factors should change the interpretation of the patent laws in order to maintain the role of patents. Or should patents instead be subject to the rise and ebb of external economic factors, declining in prominence in along with industrial sectors? One gets the sense that some Federal Circuit judges fear patents will lose prominence if the economy shifts away from industrial activities and the patent system does not follow along. Vested interests in the patent system - and judges of the Federal Circuit must fall in this category, ${ }^{166}$ though they do

changes in ideological outlook by Patent Office administrators, with "liberalizers" ideologically favoring more patent grants and "scientific men" ideologically favoring less. Robert C. Post, 'Liberalizers' Versus 'Scientific Men' in the Antebellum Patent Office, 17 TECH. \& Culture 24 (1976).

165 E.g., Classen Immunotherapies, Inc., 659 F.3d at 1075 (Rader, J., joined by Newman, J., additional views) ("[I]f one nation makes patent protection difficult, it will drive research to another, more accommodating nation."). This seems like an absurd argument, given that patent protection is typically provided regardless of the location where the invention was developed, and a researcher can forego patent protection in her native country while seeking it elsewhere.

166 Numerous commentators have alleged a pro-patent bias in the Federal Circuit. See, e.g., Jonathan Masur, Patent Inflation, 121 YALE L.J. 470 (2011) (proffering a model to explain expanding patentability); Thomas F. Cotter, Book Review: Law, Economics, and Intellectual Property, THE ANTITRUST SOURCE, Mar. 2004, at 2, available at http://www.americanbar.org/content/dam/aba/ publishing/antitrust_source/bookreview.authcheckdam.pdf. But see Lisa Larrimore Ouellette, What Are the Sources of Patent Inflation? An Analysis of Federal Circuit Patentability Rulings, 121 YALE L.J. 347 (2011) (critiquing the Masur patent inflation model). 
hear matters outside the realm of patent law-seem reluctant to place limits on the scope of patent subject matter eligibility but instead tend to adopt liberal, expansive views on patent subject matter eligibility. ${ }^{167}$ At the very least, it seems that those arguing for broad patent eligibility tend to have no concern about patents covering nonproductive activities, in a Veblenian sense. On the other side of the argument, it can be argued that an expanded scope of patentability devalues the kinds of productive technologies that, in a historical sense, have been the foundation of the patent system for centuries, and thought to be a driver of general welfare.

\section{The Constitutional Limit}

It has been suggested by numerous others that the constitutional question of what is patent-eligible subject matter is central to assessing patent eligibility for business methods and other nontechnological "inventions."168 The question has been raised across numerous judicial opinions, from the Supreme Court, lower courts, and administrative bodies. One of the clearest discussions came from the landmark case of Graham v. John Deere, interpreting the then fairly recent 1952 revisions to the patent statutes.

167 See, e.g., Michele Boldrin \& David K. Levine, The Case Against Patents, J. ECON. PERSP., Winter 2013, at 3-4 ("[T] he political demand for stronger patent protection comes from old and stagnant industries and firms, not from new and innovative ones."); Ouellette, supra note 166, at 349 (suggesting that the Federal Circuit may have been created with the purpose of increasing findings of patent validity and infringement).

168 E.g., Alan L. Durham, 'Useful Arts' in the Information Age, 1999 BYU L. REv. 1419, 1420 (1999); Richard Stern, Being Within the Useful Arts as a Further Constitutional Requirement for US Patent Eligibility, EUR. INTELL. PROP. REV. 6, 10 (2009); Thomas, supra note 97, at 4-6; John R. Thomas, The Patenting of the Liberal Professions, 40 B.C. L. REV. 1139, 1142 (1999); Robert A. Kreiss, Patent Protection for Computer Programs and Mathematical Algorithms: The Constitutional Limit on Patentable Subject Matter, 29 N.M. L. REV. 31 (1999); Malla Pollack, The Multiple Unconstitutionality of Business Method Patents: Common Sense, Congressional Consideration, and Constitutional History, 28 RUTGERS COMP. \& TECH. L.J. 61 (2002). 
At the outset it must be remembered that the federal patent power stems from a specific constitutional provision which authorizes the Congress "To promote the Progress of . . . useful Arts, by securing for limited Times to . . Inventors the exclusive Right to their . . Discoveries." Art. I, $\S 8, \mathrm{cl} .8$. The clause is both a grant of power and a limitation. This qualified authority, unlike the power often exercised in the sixteenth and seventeenth centuries by the English Crown, is limited to the promotion of advances in the "useful arts." It was written against the backdrop of the practices-eventually curtailed by the Statute of Monopolies - of the Crown in granting monopolies to court favorites in goods or businesses which had long before been enjoyed by the public. See Meinhardt, Inventions, Patents and Monopoly, pp. 30-35 (London, 1946). The Congress in the exercise of the patent power may not overreach the restraints imposed by the stated constitutional purpose. Nor may it enlarge the patent monopoly without regard to the innovation, advancement or social benefit gained thereby. Moreover, Congress may not authorize the issuance of patents whose effects are to remove existent knowledge from the public domain, or to restrict free access to materials already available. Innovation, advancement, and things which add to the sum of useful knowledge are inherent requisites in a patent system which by constitutional command must "promote the Progress of . . . useful Arts." This is the standard expressed in the Constitution and it may not be ignored. $^{169}$

169 Graham v. John Deere Co. of Kansas City, 383 U.S. 1, 5-6 (1966) 
This express linking of technology to social progress in Graham echoed views widely held when the Constitution was framed. ${ }^{170}$

[T] he Constitution dictates the interpretation of 'process', 'machine' and similar words in s.101limiting them to things within the 'useful Arts.' At the very least, it may be presumed ... that one cannot promote the progress of 'useful Arts' by rewarding or regulating activities not within the 'useful Arts.' 171

Available history regarding deliberation on this constitutional language indicates that the "useful Arts" language was specifically inserted in place of alternate language. At the constitutional convention, James Madison proposed language "To grant patents for useful inventions," "To secure to Authors exclusive rights for a certain time," and "To establish public institutions, rewards and immunities for the promotion of agriculture, commerce, trades and manufactures," all of which was rejected in favor of the language proposed a few weeks later: "To promote the Progress of Science and useful Arts, by securing for limited Times to Authors and Inventors the exclusive Right to their respective Writings and Discoveries[..]"172 The final language of the Constitution reflects a different and narrower scope of legislative authority than proposed

(emphasis added).

${ }^{170}$ Irwin, supra note 9, at 785.

171 Stern, supra note 168, at 10. This statement should be qualified by noting that the same clause allows promotion of "science" as use to provide copyrights. Stern goes on to argue for a general theory of the useful Arts and suggests a dichotomy of sorts. In reaching that conclusion, however, his explanation of "technological arts" and "industrial arts" are unsupported, and rest on shaky philosophical foundations.

${ }^{172}$ Madison Debates, August 18, 1787, The Avalon Project: Yale LAW SCHOOL, http://avalon.law.yale.edu/18th_century/debates_818.asp (last visited Mar. 13, 2012) (statement by Mr. Madison); see also Durham, supra note 169, at 1431 . 
by Madison. ${ }^{173}$ Moreover, as described in detail by Alan Durham, the term "useful arts" at the time the Constitution was drafted was used in general parlance to describe all sorts of areas of technology, engineering, craft, workmanship, and technique, but was never described as encompassing business or business methods. ${ }^{174}$ Durham notes, as has Dana Remus Irwin, that much of the confusion surrounding the scope of patentability of things like business methods can be traced to the 1952 codification of the patent laws, in which the term "art" was replaced with "process" when delineating utility requirements for patentability, without any clear intent to change the overall scope of patent-eligible subject matter. ${ }^{175}$

Recognition of constitutional limits on patent-eligible subject matter has not been discussed in great detail in more recent Supreme Court opinions, which since 1980 have focused more on statutory interpretation. Discussion of constitutional limits on patentability has been somewhat sporadic in the Federal Circuit and other lower courts. However, In re Comiskey explicitly stated that the Patent \& Copyright Clause of the Constitution "limited the subject matter eligible for patent protection to the "useful arts.",176 "The Constitution explicitly limited patentability to "the national purpose of advancing the useful arts - the process today called technological innovation.""177 That constitutional limit was used to

173 This followed the general trend of patent laws being put in place to limit monopolies, rather than to encourage them.

174 Durham, supra note 169, at 1424-44; see also Irwin, supra note 9, at 782-810 (suggesting that the 1952 patent law codification was a driver of patentable subject matter expansion and a break from the constitutional framework).

175 Durham, supra note 169, at 1425 n.24; Irwin, supra note 9, at 804-10.

176 In re Comiskey, 554 F.3d 967, 976 (Fed. Cir. 2009) (citing Graham v. John Deere Co. of Kansas City, 383 U.S. 1, 5 (1966)).

177 Id. at 977 (quoting Paulik v. Rizkalla, 760 F.2d 1270, 1276 (Fed. Cir. 1985) (en banc)); see also MySpace, Inc. v. GraphOn Corp., 672 F.3d, 1250, 1269-70 (Fed. Cir. 2012) (Mayer, J. dissenting); cf. Classen Immunotherapies, 
govern the application of statutory provisions in Comiskey, noting that "the present statute does not allow patents to be issued on particular business systems - such as a particular type of arbitrationthat depend entirely on the use of mental processes. In other words, the patent statute does not allow patents on particular systems that depend for their operation on human intelligence alone, a field of endeavor that both the framers and Congress intended to be beyond the reach of patentable subject matter." 178

Administrative agencies overseeing the U.S. patent system have tended to adopt very liberal standards for patentability. A number of years ago, the Board of Patent Appeals and Interferences (BPAI), the former name for the administrative court within the USPTO (now called the Patent Trial and Appeal Board), decided Ex parte Lundgren, ${ }^{179}$ in which the majority rejected a "technological arts" test for business method patents. ${ }^{180}$ Yet Administrative Patent Judge Jerry Smith, dissenting, took the view that a technological arts test was necessary, in that the language of

Inc. v. Biogen IDEC, 659 F.3d 1057, 1074 (Fed. Cir. 2011) (Rader, J., joined by Newman, J., additional views) ("[A]fter all, patents require a translation of technology into text, i.e., patent claims. Inevitably the subject matter exclusions of eligibility doctrines depend on the way that claims are drafted. Thus, careful claim drafting or new claim forms can often avoid eligibility restrictions. Eligibility then becomes a game where lawyers learn ingenious ways to recast technology in terms that satisfy eligibility concerns.") (emphasis added).

178 Comiskey, 554 F.3d at 980.

${ }^{179}$ Ex parte Lundgren, 76 USPQ.2d 1385, (B.P.A.I. 2005).

${ }^{180}$ Id.; see also Robert E. Thomas \& Larry A. DiMatteo, Harmonizing the International Law of Business Method and Software Patents: Following Europe's Lead, 16 TEX. INTELL. PROP. L.J. 1, 11 (2007) (noting that Lundgren rejected "the international trend towards requiring a minimal technical advancement or contribution for the patentability of business methods"). Contra Paulik v. Rizkalla, 760 F.2d 1270, 1276 (Fed. Cir. 1985) ("The exclusive right, constitutionally derived, was for the national purpose of advancing the useful arts - the process today called technological innovation."); In re Waldbaum, 457 F.2d 997, 1003 (C.C.P.A. 1972) (Rich, J., concurring) ("The phrase 'technological arts,' as we have used it, is synonymous with the phrase 'useful arts' as it appears in Article I, Section 8 of the Constitution.”). 
$\S 101$ could not be interpreted in a way that exceeds the power granted to Congress to enact that statutory section under the Patent $\&$ Copyright Clause of the Constitution. He noted that "the term 'technological arts' should be construed to mean nothing more than a threshold nexus to some field of technology to fall within the constitutional mandate."181

Some have argued that patent eligibility cannot be restricted by the Constitution. Numerous commentators have alleged a threshold on domestic patentable subject matter standards imposed by the TRIPS agreement, which would allegedly prohibit certain limits on patentable subject matter. ${ }^{182}$ However, the constitutional patentable subject matter inquiry cannot be subsumed by analysis under a treaty because the Supreme Court has repeatedly and unequivocally stated that constitutional limits override any treaty pursuant to the Supremacy Clause in Article VI, § 2. ${ }^{183}$ Moreover, the idea that other member states would object to a technological

181 Ex parte Lundgren, 76 USPQ.2d 1385, 5 (B.P.A.I. 2005) (Smith, dissenting).

182 Thomas, supra note 97, at 49; Thomas, The Patenting of the Liberal Professions, supra note 86, at 1142-43, 1177-84; Cotter, supra note 11, at 87879; see also Rajnish Kumar Rai \& Srinath Jagannathan, Do Business Method Patents Encourage Innovation, B.C. INTELL. PROP. \& TECH. FORUM 5 (2012), http://bciptf.org/wp-content/uploads/2012/10/Business-Method-Patents-andInnovation.pdf.

183 The Supreme Court "has regularly and uniformly recognized the supremacy of the Constitution over a treaty." Reid v. Covert, 354 U.S. 1, 17 (1957). "It need hardly be said that a treaty cannot change the Constitution or be held valid if it be in violation of that instrument." The Cherokee Tobacco, 78 U.S. (11 Wall.) 616, 620 (1871). See also Asakura v. City of Seattle, 265 U.S. 332, 341 (1924); United States v. Wong Kim Ark, 169 U.S. 649, 700 (1898); Geofroy v. Riggs, 133 U.S. 258, 267 (1890); Doe v. Braden, 57 U.S. (16 How.) $635,656-57$ (1853). However, purely statutory analysis would be subject to any limitation imposed by treaty. Yet Thomas does not acknowledge the Global South's position on patents, particular on medical technologies, in that the Global South despises allowing its people to die merely to preserve comparative advantages and profit margins for the North Atlantic states. See PRASHAD, supra note 79 . 
arts test on the basis of the TRIPS agreement also somewhat ignores that many other countries already have such eligibility limits and generally support them. ${ }^{184}$

In sum, the arguments in favor of a constitutional limit on patent eligibility that constrains interpretation of statutory dictates for patentability are more compelling than contrary positions. The Graham case could hardly have been clearer on that point. Arguments that treaties require expansive patent eligibility standards quickly run afoul of the Supremacy Clause and therefore fall away. All this leaves one with the impression that counterarguments for expansive patent eligibility stem from a rejection or disregard of underlying constitutional dictates and Enlightenment-era values that influenced the framing of the Constitution.

\section{Assessing Patent Eligibility at the Point of InVEntive CONTRIBUTION}

Patent eligibility could be best analyzed through an approach that focuses on the point of inventive contribution, also called a point of novelty analysis. ${ }^{185}$ This would look to the essential element(s) of the alleged solution to a technical problem as recited in a given patent claim. 'Under the 'point of novelty' approach, if the novelty or advancement in the art claimed by the inventor resided solely in a step of the process embodying a mental operation or other unpatentable element, the claim was rejected

184 See, e.g., Erstling et al., supra note 154, at 1; TRANS-PACIFIC PARTNERSHIP IP GROUP COUNTRY NEGOTIATORS, TRANS-PACIFIC PARTNERSHIP Agreement: Intellectual Property [RIGHTS] Chapter, ART. QQ.E.1 (Aug. 30, 2013), available at https://wikileaks.org/tpp/static/pdf/Wikileaks-secretTPP-treaty-IP-chapter.pdf.

185 Chao, supra note 3 , at 83, 91 (calling this subject matter eligibility analysis a "point of novelty" approach unfortunately tends to generate much confusion with what is presently a separate statutory requirement of novelty for patentability under 35 U.S.C. $§ 102)$. 
under $\S 101$ as being directed to nonstatutory subject matter."186 The reason such an approach is desirable is that broad claims, of the sort that tend to raise patent eligibility questions, are often written in such a way that they recite a desired result without any meaningful limits as to how that result is achieved through

186 Diamond v. Diehr, 450 U.S. 175, 200 n.15 (1981) (emphasis added) (citation omitted); $c f$. Application of Seid, 161 F.2d 229 (C.C.P.A. 1947) (“'A] mere matter of choice in ornamentality . . produces no new mechanical effect or advantage considered to constitute invention" and is therefore not eligible for utility patent protection.); Eskimo Pie Corp. v. Levous, 35 F.2d 120 (3rd Cir. 1929) (stating that a claim to a rectangular ice cream desert was invalidated by a prior art spherical or ball-shaped one, because " $[t]$ here is no invention in merely changing the shape or form of an article without changing its function except in a design patent"). For a proposal for a "revised" two-part point of novelty subject matter eligibility test, see Chao, supra note 186, at 94 ("If the limitation embodying the point of novelty does not describe an unpatentable concept, the claim qualifies as patentable subject matter. If the limitation embodying the point of novelty merely describes one of these unpatentable concepts, the court should proceed to the second part of the analysis - examining the other limitations. If the other limitations are not directed at an unpatentable concept and have a strong nexus with the point of novelty, the claim is patentable. The nexus requirement excludes 'insignificant post-solution activity' and other limitations that are not central to the point of novelty."). However, Chao's test still leaves some uncertainty about how to meaningfully characterize "unpatentable concepts" without the machine-or-transformation test. Id. Moreover, Chao's approach requires analysis of extrinsic evidence in order to assess the first part of the test. Id. In contrast, applying a problem-solution analysis to identify an alleged point of inventive contribution could be performed based solely on the intrinsic record of a given patent or patent application, and later analysis of whether the point of inventive contribution constitutes a productive contribution to the common stock of technical proficiency (a concept discuss further below) would tend to require relatively little analysis of extrinsic evidence. Id. Nonetheless, the plurality opinion of the Federal Circuit in CLS Bank adopted a two-part analysis similar to Chao's recommendation. CLS Bank Int'l v. Alice Corp. Pty. Ltd., 717 F.3d 1269 (Fed. Cir. 2013) (en banc) (per curiam), cert. granted, 82 U.S.L.W. 3131 (U.S. Dec. 6, 2013) (No. 13-298); accord Accenture Global Servs. v. Guidewire Software, Inc., 728 F.3d 1336, 1341 (Fed. Cir. 2013). Yet the CLS Bank plurality opinion approach still tends to require claim construction prior to patent eligibility analysis, which is a weakness of that approach. 
technical means. ${ }^{187}$ In such cases, the "how" part of the alleged invention is recited merely in terms of an abstract idea, a law of nature, or a natural phenomenon. At times, today, the "how" part is recited by only the most cursory and general reference to general purpose computers and the like-an approach that begs the question of whether reciting, essentially, that computers allow automated calculations to be performed, constitutes merely an unpatentable abstract idea unto itself. ${ }^{188}$ Alternatively, this might

${ }^{187}$ Le Roy v. Tatham, 55 U.S. (14 How.) 156, 173 (1852) (“A patent is not good for an effect, or the result of a certain process, as that would prohibit all other persons from making the same thing by any means whatsoever."). The problem of results-based claiming is explicitly addressed under guidelines for European patent practice. "As a general rule, claims which attempt to define the invention by a result to be achieved should not be allowed, in particular if they only amount to claiming the underlying technical problem." GUIDELINES FOR EXAMINATION IN THE EUROPEAN PATENT OfFice $\S 4.10$ (rev. ed. 2013). Moreover, "[t]he claims . . . must be clear, meaning not only that a claim must be comprehensible from a technical point of view, but also that it must define clearly all the essential features of the invention ...." Id. § 4.5.1. "Essential features of a claim are those necessary for achieving a technical effect underlying the solution of the technical problem with which the application is concerned (the problem usually being derived from the description). The independent claim(s) should therefore contain all features explicitly described in the description as being necessary to carry out the invention. Any features which, even if consistently mentioned in the context of the invention throughout the application, do not actually contribute to the solution of the problem are not essential features." Id. § 4.5.2.

188 Marchand v. Emken, 132 U.S. 195, 199 (1889). Some cases establish a similar proposition that one cannot merely claim the "automation" of a known manual activity without reciting a particular automation mechanism that represents an inventive contribution to an underlying technical problem. "Appellant argues that his rejected claims rest upon an automatic mechanism. The mere statement that a device is to be operated automatically instead of by hand, without a claim specifying any particular automatic mechanism, is not the statement of an invention. ... Much of the argument made here is directed to the various elements of appellant's automatic mechanism. It is sufficient to say that however inventive these elements may be, they are not mentioned in the rejected claims, and hence can have no effect upon on conclusion thereon." In re Rundell, 48 F.2d 958 (C.C.P.A. 1931) (internal citations omitted); In re Venner, 262 F.2d 91 (C.C.P.A. 1958) (internal citations omitted) ("[I]t is well settled that 
be viewed as seeking monopoly rights over a solution (that uses technology) to a social problem. Merely reciting that a machine (e.g., computer) performs a task rather than a person is not a solution to a technical problem but is instead an abstract idea regarding a social question of whether employers hire employees or purchase machines instead. Put another way, the "invention" may really be a solution to a social problem rather than a technical problem, albeit a solution that utilizes technology-typically ubiquitous technology (at least at the level of abstraction that such technology is recited in the claims). This "point of inventive contribution" approach does not simply convert the patent eligibility analysis to a consideration of novelty and/or obviousness, but rather is an insistence that the patentee or patent applicant should have to limit her claims to more than just a statement of a desired result or an essentially bare statement of a technical problem (without reciting the technical solution)something explicitly required by rule in other jurisdictions. ${ }^{189}$ In other words, claims that recite an effect (or result) must delineate both cause and effect and not merely the effect (or result) in isolation. The desired effect (or result) may be new and nonobvious, or the underlying technical problem may have been previously unsolved, but if there is no recitation in the claims of how that effect is achieved (the technical causal mechanism), then preemption and a lack of patent eligibility become meaningful concerns. These concerns appear in the backdrop of many Supreme Court cases on patent eligibility, at least when the actual claim language is considered. ${ }^{190}$ Moreover, cases like Bilski present

it is not 'invention' to broadly provide a mechanical or automatic means to replace manual activity which has accomplished the same result," and "[p]atentability cannot be predicated upon a mental step."). However, these cases treat the question as one of obviousness rather than of patent eligibility.

${ }^{189} C f$. GuIDELINES FOR EXAMINATION IN THE EUROPEAN PATENT OFFICE $\S \S$ 4.5, 4.10 (rev. ed. 2013) (requiring a technical solution).

${ }^{190}$ A problem with opinions like Gottschalk v. Benson is that they do not provide any meaningful analysis of the actual claim language at issue. See Supra Part IV.A. 
attempts to claim solutions to social allocations of wealth already in existence (e.g., hedging investment risk), which through one mechanism or another courts have historically tended to find constitute no more than unpatentable abstract ideas, or the like. In other words, proffered "solutions" to social "problems" are not generally thought of as being within the realm of the technological or useful arts. Claims like that of Bilski clearly fail a technological arts test, but asking whether a claim at the recited point of inventive contribution provides a productive contribution to the common stock of technological proficiency is a much more direct way to repeatedly reach the sorts of conclusions found in Supreme Court cases for centuries, from Marchand to Funk Brothers to Flook to Mayo. Practically speaking, courts and USPTO staff could analyze claims to identify the purported inventive contribution, and if it contains only a result or effect, without reciting the mechanism (or step) that causes it, or if it relates to a social question rather than a technical problem, then patent eligibility could be denied due to preemption. Other jurisdictions sort claims in a two-part manner like this with great success. ${ }^{191}$

Judicial precedent is highly confused when a "point of novelty" type of patent eligibility analysis is considered - comparable to the presently endorsed point of inventive contribution approach. Justice Rehnquist wrote in the Diehr case that patent subject matter eligibility cannot be assessed at the point of novelty. ${ }^{192}$ That statement seems to have been a miscalculation, and one that the Supreme Court should explicitly correct. ${ }^{193}$ In other areas of patent

${ }^{191}$ See, e.g., European Patent Convention r. 43(1).

192 Diamond v. Diehr, 450 U.S. 175, 188-89 (1981); see also Bilski v. Kappos, 130 S. Ct. 3218, 3236 (2010); In re Schrader, 22 F.3d 290, 294 (Fed. Cir. 1994). Flook stated that the Court's approach is "not at all inconsistent with the view that a patent claim must be considered as a whole." Parker v. Flook, 437 U.S. 584, 594 (1978).

193 For a contrary view, arguing that the Supreme Court was correct to disregard the point of novelty, see Mark A. Lemley, Point of Novelty, $105 \mathrm{Nw}$. U. L. REV. 1253, 1277-79 (2011). Lemley's analysis rests on somewhat dubious 
law, such as with respect to indefiniteness caused by functional claiming at the point of novelty, the Supreme Court and subsequent lower court opinions have endorsed an approach that looks to the point of novelty of a given patent claim. ${ }^{194}$ While the analysis of obviousness under 35 U.S.C. $\S 103$ requires by statute that "the claimed invention as a whole" (formerly worded as "the subject matter as a whole") be analyzed, 35 U.S.C. $\S 101$ includes no such explicit requirement for the analysis of utility. ${ }^{195}$ In other words, the statutory language of $\S 101$ does not preclude a point of inventive contribution analysis.

It continues to be a source of confusion that the Supreme Court has mostly deferred to lower court precedents barring a point of novelty analysis of patent eligibility. As a result, Judges on the Federal Circuit have struggled through the question of whether the point of novelty, or something like it, should be considered in assessing patent subject matter eligibility. For example, in the nonprecedential opinion for Smartgene, Inc. $v$. Advanced Biological Labs, SA, a Federal Circuit panel noted that the method claim at issue "calls on a computer to do nothing that is even arguably an advance in physical implementations of routine mental information-comparison and rule-application processes." 196 Such a statement hints that the recitation of a "computer" does not fall at the point of inventive contribution, that is, the computer does not

assumptions about expansive patent grants always being desirable, of the sort routinely criticized by economists. $I d$ at 1279 .

194 E.g., Halliburton Oil Well Cementing Co. v. Walker, 329 U.S. 1 (1946); Halliburton Energy Servs., Inc. v. M-I LLC, 514 F.3d 1244 (Fed. Cir. 2008); Ex parte Miyazaki, 89 USPQ.2d 1207 (B.P.A.I. 2008), Greenberg v. Ethicon EndoSurgery Inc., 91 F.3d 1580, 1584 (Fed. Cir. 1996); see also In re Abrams, 188 F.2d 165, 166,170 (C.C.P.A. 1951).

195 Compare 35 U.S.C. $\S 103(a)$ (2011) (pre-AIA), and 35 U.S.C. $\S 103$ (2014) (post-AIA), with 35 U.S.C. § 101 (2014).

196 Smartgene, Inc. v. Advanced Biological Labs, SA, No. 2013-1186, 2014 WL 259824, at *5 (Fed. Cir. Jan. 24, 2014) (nonprecedential). 
relate to any alleged technological advance. ${ }^{197}$ On the other hand, the opinion for Accenture Global Services v. Guidewire Software, Inc. quoted the en banc plurality opinion of CLS Bank as saying that to assess preemption of an abstract idea "the court must first 'identify and define whatever fundamental concept appears wrapped up in the claim." 198 This approach on its face seems indefensible. What is the "invention" for purposes of a patentability analysis if not what is claimed ${ }^{199}$ The Federal Circuit made a clearer point with a seemingly contrary statement in another, earlier case. "In considering patent eligibility under $\S 101$, one must focus on the claims. This is because a claim may 'preempt' only that which the claims encompass, not what is disclosed but left unclaimed." 200 These statements seem to be premised on conflicting ideas of what should be assessed for patent eligibility, and how that should be done-a question of which of the seemingly conflicting rationales of cases like Flook or Diehr should be applied.

Most recent case law under the machine-or-transformation test for patent eligibility has focused on attempts (in view of the

197 Cf., e.g., Alexsam, Inc. v. IDT Corp., 715 F.3d 1336, 1349-50 (Fed. Cir. 2013) (Dyk, J., dissenting).

198 Accenture Global Servs. v. Guidewire Software, Inc., 728 F.3d 1336, 1341 (Fed. Cir. 2013) (quoting CLS Bank Int'l v. Alice Corp., 717 F.3d 1269, 1282 (Fed. Cir. 2013) (en banc)); see also CyberSource Corp. v. Retail Decisions, Inc., 654 F.3d 1366, 1374 (Fed. Cir. 2011) ("Regardless of what statutory category ('process, machine, manufacture, or composition of matter,' 35 U.S.C. $§ 101)$ a claim's language is crafted to literally invoke, we look to the underlying invention for patent-eligibility purposes.").

199 See, e.g., Ultramercial, Inc. v. Hulu, LLC, 722 F.3d 1335, 1355 (Fed. Cir. 2013) (Lourie, J., concurring) ("While a computer or complex computer program . . . may be necessary to perform the method, it is not what the claim specifically requires[.]"); In re Rundell, 48 F.2d 958 (C.C.P.A. 1931) ("Much of the argument made here is directed to the various elements of appellant's automatic mechanism. It is sufficient to say that however inventive these elements may be, they are not mentioned in the rejected claims, and hence can have no effect upon on conclusion thereon.").

200 Dealertrack v. Huber, 674 F.3d 1315, 1334 (Fed. Cir. 2012). 
hopelessness of making software and business methods satisfy the "transformation" prong) ${ }^{201}$ by patent owners (or applicants) to recite a computer to satisfy the "machine" prong. These cases push toward something like an analysis at the point of inventive contribution. For instance, in the frequently-cited CyberSource opinion, a Federal Circuit panel stated that "the incidental use of a computer to perform [a] mental process . . . does not impose a sufficiently meaningful limit on . . claim[] scope."202 In another opinion, it was held that where "[t]he claims are silent as to how a computer aids the method, the extent to which a computer aids the method, or the significance of a computer to the performance of the method. The undefined phrase 'computer aided' does not make the claimed concept any less abstract than an underlying abstract idea. ${ }^{203}$ "Simply adding a 'computer aided' limitation to a claim covering an abstract concept, without more, is insufficient to render the claim patent eligible." ${ }^{204}$ In one of the clearest statements the Federal Circuit has issued on this point, it was held that "[i]n order for the addition of a machine to impose a meaningful limit on the scope of a claim, it must play a significant part in permitting the claimed method to be performed, rather than function solely as an obvious mechanism for permitting a solution

201 Courts have made clear that little if anything outside the realm of manufacturing methods can satisfy the "transformation" prong. "The mere manipulation or reorganization of data . . . does not satisfy the transformation prong." CyberSource, 654 F.3d at 1375. An "abstract concept cannot be transformed into patentable subject matter merely because of connections to the physical world through deeds, contracts, and real property." Fort Properties, Inc. v. American Master Lease LLC, 671 F.3d 1317, 1322 (Fed. Cir. 2012); $c$. Cochrane v. Deener, 94 U.S. 780, 788 (1877) (“A process is a mode of treatment of certain materials to produce a given result. It is an act, or a series of acts, performed upon the subject-matter to be transformed and reduced to a different state or thing.").

202 CyberSource, 654 F.3d at 1375.

203 Dealertrack, 674 F.3d at 1333.

${ }^{204}$ Id. (citing SiRF Tech., Inc. v. Int'1 Trade Comm'n, 601 F.3d 1319, 1333 (Fed. Cir. 2010)); accord Fort Properties, Inc., 671 F.3d at 1323. 
to be achieved more quickly, i.e., through the utilization of a computer for performing calculations."205 Yet, unfortunately, though that statement added the term "obvious" to the subject matter eligibility standard, it was added in such a way that still breeds confusion.

The trickiest aspect of analysis under the "machine" prong of the machine-or-transformation test remains the assessment of mental processes. There appears to be agreement on the Federal Circuit that purely mental processes are not patent-eligible because they constitute abstract ideas. ${ }^{206}$ "Merely claiming a software implementation of a purely mental process that could otherwise be performed without the use of a computer does not satisfy the machine prong of the machine-or-transformation test." 207 Yet this mental process analysis places a heavy burden on the patent examiner or court addressing the question. It generally requires comparison to a hypothetical - an unclaimed mental process. In CyberSource, ${ }^{208}$ the court had an admission by the CEO of the company that owned the patent that the method had actually been performed mentally in the past, ${ }^{209}$ and in Fort Properties the patent owner admitted during prosecution that the use of a computer was not necessary. ${ }^{210}$ Those admissions are the sorts of "golden facts" not available with respect to most patents or patent applications. A

205 SiRF Tech., 601 F.3d at 1333; cf. Marchand v. Emken, 132 U.S. 195, 199 (1889).

${ }^{206}$ E.g., CyberSource, 654 F.3d at 1377; Ultramercial, Inc. v. Hulu, LLC, 722 F.3d 1335, 1354 (Fed. Cir. 2013).

${ }^{207}$ CyberSource, 654 F.3d at 1375; cf. SiRF Tech., 601 F.3d at 1332-33 ("We are not dealing with a situation in which there is a method that can be performed without a machine.").

208 CyberSource dealt with not only method claims but also a so-called Beauregard claim, which recited a "computer readable medium containing program instructions" that are executed by one or more computer processors to carry out recited steps (i.e., method or process recitations).

${ }^{209}$ CyberSource, 654 F.3d at 1373.

210 Fort Properties, 671 F.3d at 1319 (applicant represented during prosecution that the recited methods "need not be performed by a computer"). 
patent examiner would typically not have the benefit of such admissions on the record and is therefore forced to hypothesize about the possibility of mental execution. Examiners, often quite rightly, tend to struggle with such mental exercises that are not based on evidence of record, ${ }^{211}$ potentially leading to the issuance of a patent claims drawn to non-patent-eligible subject matter. The same problems arise for judges in litigation. ${ }^{212}$ Any doctrine that tends to require an admission by the patent applicant or owner that the invention could be performed mentally is problematic because a clever patent applicant or owner can simply avoid making such an admission. But by looking at the point of novelty in a claim, that is to say the point where the essential element of a solution to an underlying technical problem is recited, trivial connections to tangible, non-mental things like computers can be disregarded when they are not implicated at the alleged point of novelty. For instance, much greater clarity on patent subject matter eligibility could be achieved if the United States required by statute that patent claims be in two-part form as required in Europe, ${ }^{213}$ with known, prior art elements separated from the recitation of the asserted inventive contribution. ${ }^{214}$

211 The main problem is that the examiner or other person assessing patent eligibility must effectively "invent" beyond the recited claim in order to analyze it, which make the entire patentability analysis look like a farce.

212 Indeed, when a Federal Circuit panel decided Smartgene, Inc. v. Advanced Biological Labs, SA, No. 2013-1186, 2014 WL259824 (Fed. Cir. 2014) (nonprecedential), under a "mental steps" analysis without the benefit of an admission in the record as in Fort Properties or CyberSource, the opinion was published as nonprecedential.

213 This format is called Jepson form in the United States and is permitted but is not required.

${ }^{214}$ European Patent Convention Rules Relating to Fees, EUR. PAT. OfF., r. 43(1), at 370 (Oct. 2013), http://documents.epo.org/projects/babylon/eponet.nsf/ 0/00E0CD7FD461C0D5C1257C060050C376/\$File/

EPC_15th_edition_2013.pdf ("The claims shall define the matter for which protection is sought in terms of the technical features of the invention. Wherever appropriate, claims shall contain: (a) a statement indicating the designation of 
In the Veblenian view, outlined further below, the dichotomy between industrial and pecuniary activity suggests looking at where the alleged gain from a claimed invention falls, in a functional sense. If the proffered gain falls not within a technological function, but within pecuniary or social spheres, then the claim is directed to nonpatentable subject matter. For instance, if a claim merely outlines the scope of the creative monopoly desired by way of patent (i.e., the desired social consequence), but does not delineate a contribution to the common stock of technical knowledge, it fails to escape the purview of the pecuniary and therefore should be deemed to lack the particular quid pro quo required for a patent grant. This analysis can most meaningfully be addressed by looking to the point of novelty or undertaking a problem/solution analysis similar to what is performed under many foreign patent law regimes in certain patentability contexts. When U.S. courts resist such an approach, they only foster confusion and abuse.

\section{GENERAL CONTOURS OF THE NEW THEORY}

\section{A. The Veblen Dichotomy}

Thorstein Veblen introduced what is now commonly referred to as the "pecuniary-industrial dichotomy," the "ceremonialtechnological dichotomy," the "ceremonial-instrumental dichotomy," or sometimes even simply the "Veblen dichotomy.",215

[T]he central feature of Veblen's work . . . was

the subject-matter of the invention and those technical features which are necessary for the definition of the claimed subject-matter but which, in combination, form part of the prior art; (b) a characterising portion, beginning with the expression 'characterised in that' or 'characterised by' and specifying the technical features for which, in combination with the features stated under sub-paragraph (a), protection is sought.").

${ }^{215}$ O'Hara, supra note 14, at 94. Clarence Ayres restated Veblen's concept as the "ceremonial-technological dichotomy." RICK TILMAN, THORSTEIN Veblen \& John Dewey, C. Wright MiLls AND the Generic ENDS OF LiFE 107 (Rowman \& Littlefield 2004). 
his development and use of the dichotomy between business and industry, what his disciples were later to call the 'ceremonial-technological dichotomy'. They and Veblen employed it as an analytical device, as an approach to the larger problem of value in economics and as part of a theory of social change. In his usage, the dichotomy was extended to include salesmanship as opposed to workmanship, free income versus tangible performance, individual gain as opposed to community serviceability, invidious emulation versus technological efficiency, and competitive advertising versus the provision of valuable information and guidance. To Veblen much of the activity that the business community engaged in was wasteful and futile, for the profitability of market exchange did not necessarily measure its social value in achieving the generic ends of life. However, he was not adequately specific about which pursuits are industrial and which are businesslike or which have both traits. Nevertheless, it is clear in retrospect that such judgements [sic] depend on the meaning assigned by Veblen to 'fullness of life, impersonally considered' which was his way of indicating that the 'generic ends of life' are transcultural in nature and often not served by profit-making. ${ }^{216}$

This was not a bright-line test in terms of the particular industry or businesses involved, but rather dealt with the processes and functions involved. ${ }^{217}$ When sorting processes according to the

${ }^{216}$ Rick Tilman, Thorstein Veblen (1857-1929), supra note 13, at 167; see also JONATHAN NITZAN \& SHIMSHON BICHLER, CAPITAL AS POWER: A STUDY OF ORDER AND CREORDER (Routledge 2009); Nitzan, supra note 29, at 169.

217 TILMAN supra note 215, at 93-108; see also R.L. Brinkman, Culture in Neoinstititional Economics: An Integration of Myrdal and Galbraith Into the 
dichotomy, "[i]t is a question of the character of the process rather than a question of the contrivances employed." 218 Veblen believed that the functional character of technology is its application to natural forces involving labor, materials and energy: "[K]nowledge is useful, or may be made so, by applying it to control of the processes in which natural forces are engaged. This employment of scientific knowledge for useful ends is technology . . . .219 Technology and the machine process ${ }^{220}$ deal with "impersonal, dispassionate insight into the material facts with which mankind has to deal." 221 Veblen wrote at length about how he saw the "instinct of workmanship" fostering the useful employment of science and technology to contribute to the "material well-being" and "biological success" of the human race. ${ }^{222}$ His interest was in

Veblen-Ayres Matrix, 40 AM. J. OF ECONOMICS AND SocIOLOGY, 401, 402-04 (1981).

218 VEBLEN, supra note 20, at 6.

219 Veblen, The Place of SCIEnCE In MODERn Civilisation, supra note 29, at 16; see also Geoffrey M. Hodgson, Veblen and Darwinism, 14 INT'L REV. OF SociologY 343, 344 (2004) (providing that the Darwinism that Veblen adopted "means causal explanation, where a cause is understood as necessarily involving transfers of matter or energy. Divine, spiritual, miraculous or uncaused causes are ruled out. Explanations of outcomes are in terms of connected causal sequence."); see also, e.g., THORSTEIN VEBLEN, ABSENTEE OWNERSHIP AND BUSINESS ENTERPRISE IN RECENT TIMES: THE CASE OF AMERICA 231 n.1, 236 (Viking Press 1938) (1923).

220 In Veblen's usage, the "machine process" was a component of "technology" separated by a level of abstraction. Schatzberg, supra note 19, at 503.

221 Veblen, The Place of Science in Modern Civilization, supra note 219 , at 1 .

222 VEBLEN, supra note 8, at 25. Veblen saw the instinct of workmanship rivaled only by the "parental bent" (with both of those instincts competing with the acquisitive instinct); see also Reinert, supra note 18, at 65 (identifying in Veblen productive proclivities, and the unproductive instinct of predation); $c f$., e.g., Naomi Klein, How Science Is Telling Us All to Revolt, NEW STATESMAN (Oct. 29, 2013), http://www.newstatesman.com/2013/10/science-says-revolt (positioning scientists against financiers when modeling how climate catastrophe and possible extinction of the human species might be avoided). 
productivity gains from labor-and-energy-driven capital. ${ }^{223}$ The functional character of invidious business or pecuniary activity, in contrast to industrial activity, is culturally or socially contextdependent and not generally limited by labor or energy scarcity. Much of Veblen's thinking about engineering in this respect showed some affinity with German economists (especially the German Historical School) and demonstrated high regard for German industrial practices, in which the concept of Technik drew a connection between useful, practical skills and knowledge. ${ }^{224}$ "In

223 Michael Hudson, Veblen's Institutionalist Elaboration of Rent Theory, Speech given at the Veblen, Capitalism and Possibilities for a Rational Economic Order Conference, Istanbul, Turkey (June 6, 2012), available at http:/ /michael-hudson.com/2012/07/veblens-institutionalist-elaboration-of-renttheory/; see also Paul N. Goldstene, Veblen's Theory of Value and the Problem of Revolution, 6 INT'L J. POL. CULTURE \& SOC'Y 507, 511-16 (1993).

224 Robert R. Locke, Reassessing the Basis of Corporate Business Performance: Modern Financial Economics' Profit Control Versus Integrated People and Process Improvement, 64 REAL-WORLD ECON. REV. 110, 110, 11520 (2013), available at http://www.paecon.net/PAEReview/issue64/ whole64.pdf. Eric Schatzberg has discussed Veblen's pivotal role in importing the concept of Tecknik to America, and highlighting how subsequent thinkers lost much of Veblen's nuance. Schatzberg, supra note 19, at 487-88; VEBLEN, supra note 36, at 181-189. Veblen saw the predominance of "captains of industry" over "captains of finance" as key to the rise of imperial Germany leading up to World War I. More generally, some of Veblen's contemporaries who shared many theoretical similarities were Werner Sombart and Simon Patten. See, e.g., Thorstein Veblen, ANNALS OF THE AMERICAN ACADEMY OF Political AND SoCIAL SCIENCE 125 (1899) (reviewing SimON N. PATTEN, THE DEVElopMent OF ENGlish THOUght: A STUdy IN THE ECONOMIC INTERPRETATION OF HISTORY (1899)); Thorstein Veblen, Book Review, $11 \mathrm{~J}$. POL. ECON. 300 (1903) (reviewing WERNER SOMBART, DER MODERNE Kapitalismus (1902)); Thorstein Veblen, Book Review, 23 J. POL. ECON. 846 (1915) (reviewing WERNER SOMBART DER BOURGEOIS: ZUR GEISTESGESCHICHTE DES MODERNEN WIRTSCHAFTSMENSCHEN (1913)). Veblen's work also reflected in some ways that of Henry George. See, e.g., Jim Horner \& John Martinez, Thorstein Veblen and Henry George on War, Conflict, and the Military: An Institutionalist Connection, 31 J. ECON. IssUES 633 (1997); James H. Horner, Seeking Institutionalist Signposts in the Work of Henry George: Relevance Often Overlooked, 52 AM. J. ECON. \& SoC. 247 (1993). 
Germany the idea of Technik [the combination of Können (practical skills and industrial arts) and Wissen (knowledge)] was the essence of engineering ...."225

Veblen outlined clear distinctions between "the kind of [productive] self-interest which contributes to wealth creation from that which constitutes predatory wealth extraction. ${ }^{" 226} \mathrm{He}$ described the socially and culturally determined monetary gains of accumulated wealth and "assets" in contradistinction to technological capital. Although the so-called "cumulative causation" aspect of his thinking is often disregarded or misunderstood, ${ }^{227}$ he said that pecuniary gains of wealth and "assets" "are 'timeless,' . . . in so far as the enterprise from which they accrue is dissociated from the technological circumstances and processes of industry, and only in so far. Technological (industrial) procedure, being of the nature of physical causation, is subject to the time relation under which causal sequence runs." 228 That is not to say that business and pecuniary functions do not have deep and wide-ranging influence, but their social contingency lends them a different character than technology and the machine process. In this sense, nontechnological activities can essentially be divorced from the causally-linked evolution of the state of the art

${ }^{225}$ Locke, supra note 224, at 110, 115-20.

${ }^{226}$ Reinert, supra note 18, at 58; HUDSON, supra note 10, at xiv, xviii, 105, $130,133,383,435$ (explaining the financial sector "seeks to make money from the economy in an extractive way. Finance today is acting in a way that deindustrializes economies, not builds them up." "[T]he idea of 'wealth creation' has come to refer to raising the price of stocks and bonds that represent claims on wealth ('indirect investment') rather than direct investment in capital spending, research and development to increase production.").

227 See Malcolm Rutherford, Veblen's Evolutionary Programme: a Promise Unfulfilled, 22 CAMBRIDGE J. ECON. 463 (1998).

228 Veblen, On the Nature of Capital, supra note 8, at 129; see also VEBLEN, supra note 20, at 37 (describing the machine process by saying "[i]ts metaphysics is materialism and its point of view is that of causal sequence"). 
(in the Darwinian sense). ${ }^{229}$ Put more simply, technology is transcultural, while pecuniary activity is not. Technological advance faces different constraints than pecuniary activities, and Veblen recognized that such a divergence could lead to various price manipulations like over-capitalization (e.g., watered stock) and credit bubbles brought about by pecuniary activities, which can have disastrous effects on the economy as a whole. ${ }^{230}$ In the practice of patent law, this is often seen with method claims that use technology but are directed, at bottom, to only business practices that merely direct the benefit of that use without overcoming a problem associated with the current state of the technological arts. ${ }^{231}$ Decisions on how to allocate benefits, wealth, and economic value are purely social matters of a different character than the "matter of fact" (objective) constraints on knowledge of cause and effect involved in solving technical problems. Allocations of value produce no net gain, they just reposition actors within a social matrix (i.e., relative social status changes), while advances in technical knowledge have potential to provide a net gain in terms of increases in general well-being and standards of living.

Others have articulated similar dichotomies, such as architect, engineer, and futurist R. Buckminster Fuller's "Class-One" and

${ }^{229}$ See Geoffrey M. Hodgson, Veblen and Darwinism, 14 INT'L REV. SoC. 343, 345-48 (2004) (explaining Veblen's Darwinian views on "cumulative causation"); see also Alfred E. Kahn, Fundamental Deficiencies of the American Patent Law, 30 AM. ECON. REV. 475, 479 (1940).

${ }^{230}$ See Wray, supra note 13, at 618.

${ }^{231}$ Although elsewhere this paper criticizes the use of hypotheticals to test patentable subject matter eligibility (such as whether a method could hypothetically be performed purely mentally), there is the possibility that a test could ask hypothetically whether a patent claim would make sense if placed in a different cultural context. For instance, if a patent claim relates to the legal obligations associated with deeds to real property, one could ask if the claim would present any productive benefit if practiced in another jurisdiction where all land is owned by a monarch or the state, or where the "rule against perpetuities" does not exist, etc. 
"Class-Two" evolutionary trending distinction. The former represents the "integration of experience-won information" that "increase[s] the capacity of humanity at large to cope with the exigencies of life" in a way that "accounts for humans' presence on Earth," while the latter represents "ego-flattering," "initiative taking," "political reform," credit taking, "power-structure," "privilege," and "manipulation"-related activities. ${ }^{232} \mathrm{He}$ used the term "ephemeralization" to describe doing more with less through technological advancement. ${ }^{233}$ Fuller's comments are in a sense a mere extension of Veblen's theories.

Similar distinctions have been echoed in the realm of legal commentary. The Veblen dichotomy was mirrored in some ways by an influential 1952 article by patent attorney Robert Coulter, which distinguished useful arts as practiced by tradesmen from cultural arts that he described to include grammar, logic, rhetoric, arithmetic, geometry, music and astronomy. ${ }^{234}$ Likewise, a similar approach was suggested more recently by John Thomas, who said:

By restricting patentable advances to the repeatable production or transformation of material objects, and excluding subject matter founded upon the aesthetic, social observation or personal skill, [an] industrial application requirement would restore a sense of patentable subject matter that matches our sensibilities. ${ }^{235}$

Yet Coulter and Thomas' approaches can be greatly refined and bolstered with reference to Veblen's economics, by tying the

232 R. BUCKMINSTER FULLER, CRITICAL PATH 229-30 (1981).

233 R. BUCKMINSTER FulLER, Nine CHAINS TO THE MOON 276-79 (1938).

${ }^{234}$ Robert I. Coulter, The Field of the Statutory Useful Arts, 34 J. PAT. OFF. SOC'Y 417, 496 (1952).

235 John R. Thomas, The Post-Industrial Patent System, 10 FORDHAM INTELl. Prop. MEDIA \& ENT. L.J. 3,7 (1999); see also John R. Thomas, The Patenting of the Liberal Professions, 40 B.C. L. REV. 1139, 1142, 1177-84 (1999). 
analysis to economic well-being in the real world rather than merely alluding to historical traditions and arbitrary customs. ${ }^{236}$

Prior judicial decisions have held that a claim cannot carve out a portion of an abstract concept for patent protection merely on the basis reciting an incidental machine, computer or broad field of endeavor. ${ }^{237}$ Such claims amount to merely reserving a portion of the commercial market for an abstract idea (i.e., use of the abstract idea in a given technological environment) without regard for any technological contribution to public knowledge or restrictions on further innovations by others. ${ }^{238}$ Claims that are "preemptive of a fundamental concept or idea that would foreclose innovation" in a

236 Thomas' paper on the "post-industrial patent system" makes no reference to any of the various sociologists alternatively credited with coining the term "post-industrial society," or to Veblen or any other economists. He instead focuses on philosophers of science. Paul W. DeVore, cited by Thomas, echoes some views similar to Veblen, nonetheless. Although Thomas refers to "restor[ing] a sense of patentable subject matter that matches our sensibilities," and "our long-held sense of the reach of the patent system," he provides no explanations for the economic or cultural bases for those "sensibilities" or "long-held sense," only more philosophical ones. Thomas, The Post-Industrial Patent System, supra note 235, at 43-44; Thomas, The Patenting of the Liberal Professions, supra note 235, at 1142.

237 E.g., Dealertrack, Inc. v. Huber, 674 F.3d 1315, 1334 (Fed. Cir. 2012). (citing Bilski v. Kappos, 130 S. Ct. 3218, 3231 (2010); Diamond v. Diehr, 450 U.S. 175, 191 (1981)); see also Marchand v. Emken, 132 U.S. 195, 199-200 (1889).

238 See, e.g., Brenner v. Manson, 383 U.S. 519, 534 (1966) ("The basic quid pro quo ... for granting a patent monopoly is the benefit derived by the public from an invention with substantial utility."); Pennock v. Dialogue, 27 U.S. (2 Pet.) 1, 23 (1829) (If an invention is already commonly known and used when the patent is sought, "there might be sound reason for presuming, that the legislature did not intend to grant an exclusive right," given the absence of a "quid pro quo."); Mayo Collab. Servs. v. Prometheus Labs, Inc., 132 S. Ct. 1289, 1301-02 (2012) (noting how problematic rent seeking is associated with preemptive patent claims); MySpace, Inc. v. GraphOn Corp., 672 F.3d 1250, 1266,1269 (Fed. Cir. 2012) (Mayer, J., dissenting). 
given area are too abstract to be eligible for patent protection. ${ }^{239}$ The problem of preemption is only overcome with a reduction in the level of abstraction by tying the inherent pecuniary aspects of a patent monopoly (discussed below) to the recitation of productive contributions to the general stock of technological knowledge of cause-and-effect relationships. Cases on the issue of patent eligibility have seen judges wrangle over where such a threshold is crossed (or if the threshold is even a meaningful one) ${ }^{240}$ and have set forth many different tests and clarifications that lack uniformity. ${ }^{241}$ But such a threshold could be clearly established with reference to the Veblen dichotomy. It is possible to fairly consistently translate judicial concern over "abstract ideas" as an underlying concern for patent protection on what Veblen called "invidious" or "pecuniary" activity, with the level of abstraction reduced sufficiently for patent eligibility only when patent claims are tied to workmanlike technological activity. ${ }^{242}$

\section{B. Economic Surplus and Productivity}

A distinction can be drawn between technological advances that can create economic surplus or wealth (which can later be disposed of any a variety of ways), and ceremonial, business or social endeavors that control economic value or surplus or wealth

${ }^{239}$ Dealertrack, 674 F.3d at 1333; see also Mayo, 132 S.Ct. at 1301-02; Gottschalk v. Benson, 409 U.S. 63, 91-92 (1972).

${ }^{240}$ E.g. Ultramercial, Inc. v. Hulu, LLC, 722 F.3d 1335, 1342, 1353 (Fed. Cir. 2013) ("[T]his court does not define the level of programming complexity required before a computer-implemented method can be patent-eligible.").

${ }^{241}$ See generally CLS Bank Int'l v. Alice Corp. Pty. Ltd., 717 F.3d 1269 (Fed. Cir. 2013) (en banc) (per curiam), cert. granted, 82 U.S.L.W. 3131 (U.S. Dec. 6, 2013) (No. 13-298).

242 Today it is really only the subset of Federal Circuit judges advocating an expansive "coarse filter" approach to patent eligibility who diverge from this tenet. See Classen Immunotherapies, Inc. v. Biogen IDEC, 659 F.3d 1057, 1066 (Fed. Cir. 2011); Research Corp. Techs., Inc. v. Microsoft Corp., 627 F.3d 859, 869 (2010). 
already in existence. ${ }^{243}$ This was a major feature of Veblen's 1914 book, The Instinct of Workmanship and the State of the Industrial Arts, which described transformations in society whereby economic surpluses were first created by technological advances but then looted, appropriated, and subverted, through war in early phases of civilization and then by the sabotage and appropriations of the pecuniary business interests in later phases. ${ }^{244} \mathrm{He}$ thought, however, that modern technology was so productive that historical examples failed to impress the significance of how the wastefulness of nonproductive pecuniary activities parasitically detracted from general welfare. ${ }^{245}$ Although Veblen was not the

243 Dugger, Veblen's Radical Theory of Social Evolution, supra note 15, at 651; Rick Tilman, A Veblen TREasury: From Leisure Class to War, Peace, and Capitalism xxiv (Sharpe 1993); STEPhen Edgell, Veblen in PERSPECTIVE: HIS LIFE AND ThOUGHT 77 (Sharpe 2001); O'Hara, supra note 14.; Reinert, supra note 18, at 58-69 ("A major achievement of Enlightenment economics, on which I argue Veblen builds, was to separate the economic activities where the vested interests contributed to the common good-where wealth-production was a by-product of self-interest and greed - and where greed produced no such beneficial effects."); Mitchell, supra note 15, at 392; Dugger, Veblen and Kropotkin on Human Evolution, supra note 15, at 978; cf. JOHN Rae, Statement of Some New Principles on the SubJect of Political ECONOMY, EXPOSING THE FALlACIES OF THE SYSTEM OF FREE TRADE, AND OF SOME OTHER DOCTRINES MAINTAINED IN THE "WEALTH OF NATIONS" (1834), available at http://books.google.com/books?id=4TXAAAAMAAJ\&printsec=frontcover\#v=onepage \&q\&f=false; Brewer, supra note 13; see also Schatzberg, supra note 19, at 499 ("[I]n essence [Veblen's expressed conflict between "business" and "industry"] centered on the distinction between wasteful and productive tendencies in human evolution.").

244 Sociologist C. Wright Mills, for one, elaborated on the ceremonialtechnological distinction in the context of industrial relations in later historical phases, focusing on the ways in which industrial managers deal with workers to achieve ceremonial ends rather than technological ones. TILMAN supra note 215, at 107.

245 VEBLEN, supra note 20, at 36, 64-65 ("In so far as the gains of . . . unproductive occupations are of a substantial character, they come out of the aggregate product of other occupations in which the various classes of the community engage. ... But owing to the very high productive efficiency of the modern mechanical industry, the margin available for wasteful occupations and 
first or last economic theorist to discuss concepts that surround surplus value, he went further than those before him in illustrating the relationship of social institutions to the control of such value. ${ }^{246}$ His particular emphasis on the control of surplus to bolster social status represents a significant departure from (if not an implicit refutation of) Say's law_- "supply creates its own demand"which is the foundation of much of neoclassical economics and the equilibrium theories that Veblen despised yet dominate orthodox economics to this day. ${ }^{247}$ This also allowed Veblen to completely abandon the labor theory of value relied upon by classical

wasteful expenditures is very great."); see also Hudson, supra note 223 ("It was left to Veblen to deal with the rentiers' increasingly dominant yet corrosive role, extracting their wealth by imposing overhead charges on the rest of society."); HUDSON, supra note 10, at xiv, xviii, 105, 130, 133, 383, 435 ("The banking system has been decoupled from the real economy. The financial sector's independent and self-referential expansion path is independent of the 'real' economy's surplus, or its ability to support this overhead. Financial returns are made in extractive ways, as a subtrahend from the surplus created by labor and tangible capital, rather than funding capital accumulation. Productivity is raised by working labor harder and exploiting it more, not by technology." "The banker's 'product' is society's debt overhead.").

246 Veblen drew this long-established concept from classical economics. HUDSON, supra note 10, at 19-203 (summarizing relevant classical economic theory, including that of surplus value). An important early example was François Quesnay of the French physiocrat school, whose TABLEAU ÉCONOMIQUE (1759) outlined economic interactions between "productive," "proprietary," and "sterile" classes. Quesnay, however, emphasized agriculture over industry, for largely chauvinistic reasons given the greater role of agriculture in France as compared to England, France's chief rival at the time.

247 Adil H. Mouhammed, Veblen and Keynes: On the Economic Theory of the Capitalist Economy, 155 J. InSTITUTIONAL \& THEORETICAL ECON. 594, 599600 (1999); see also Debunking Economics, Part VIII: Macroeconomics, or Applied Microeconomics?, UnLEARNING ECON. (Aug. 26, 2012), http:// unlearningeconomics.wordpress.com/2012/08/26/debunking-economics-part-

viii-macroeconomics-or-applied-microeconomics (citing STEVE KEEN, DEbunking ECONOMICS : THE NAKED EMPEROR DETHRONED? (2011)). Contra Say's Law, WIKIPEDIA, https://en.wikipedia.org/wiki/Say\%27s_Law (last modified Mar. 17, 2014). 
economists like Adam Smith and David Ricardo. ${ }^{248} \mathrm{He}$ instead posited value as being pecuniary (i.e., based on money), and in turn saw money as being endogenous - a social creation-with humans engaging in production to acquire money as a representation of social status and power. ${ }^{249}$ The late sociologist Pierre Bourdieu, in championing a return to the challenge put forth by institutional economics, noted that it was Veblen who "long ago enunciated the effects of structure, or of position within a structure, on the definition of needs and hence on demand." 250 In this way, Veblen represented a singular voice on the fundamental economic question of how "value" is conceptualized.

Importantly, Veblen's dichotomy "breaks the link between production and distribution." ${ }^{251}$ In doing so, a novel theory of economic value is introduced, albeit somewhat obliquely. ${ }^{252}$ Distribution of socially-recognized assets had a different character than the industrial activities that provide the means of production. It is the existential notion of absurdity (Veblen instead preferred the term opacity) that anchors Veblen's argument for differentiating productive and unproductive functions in economic

248 O'Hara, supra note 14, at 90-93; Dugger, supra note 13, at 1; see also Labor Theory of Value, WIKIPEDIA https://en.wikipedia.org/wiki/ Labor_theory_of_value (last modified Mar. 11, 2014).

249 G. Parker Foster \& B. Ranson, Thorstein Veblen on Money and Production, 9 ECON. ET SOCIETIES 221 (1987), reprinted in 2 THORSTEIN VEBLEN: CRITICAL ASSESSMENTS 444-49 (John Cunningham Wood ed., Routledge 1993) (noting how Veblen's thinking here anticipated that of John Maynard Keynes); L. Randall Wray, Endogenous Money: Structuralist and Horizontalist 4 (Levy Econ. Inst., Working Paper No. 512), available at http:// www.levyinstitute.org/pubs/wp_512.pdf.

250 BOURDIEU, supra note 40, at 211.

251 TILMAN, supra note 215, at 97 (citing Thorstein Veblen, Industrial and Pecuniary Employments, 3 PUBLICATIONS OF THE AMERICAN ECONOMIC ASSOCIATION 190, 215-16 (1901)).

252 Paul N. Goldstene, Veblen's Theory of Value and the Problem of Revolution, 6 INT'L J. POL. CULTURE \& SOC'Y 507, 511-16 (1993). 
analysis, ${ }^{253}$ and likewise can anchor an argument against extending patent protection to unproductive functions.

\section{Asset Relationships}

Veblen noted the different characters of tangible and intangible assets, on the one hand, and capital goods on the other. ${ }^{254}$ Both are ways in which products and processes are capitalized. A given item may have characteristics of both, in varying degrees. Tangible assets are rather self-explanatory, yet intangible ones raise deeper issues. Letters patents were noted in his analysis for their character as intangible assets, due to their special legal status that grants the patent holder a right to exclude others from practicing the claimed invention.

The tangible assets capitalize the preferential use of technological, industrial expedients, expedients of production, dealing with the facts of brute nature under the laws of physical cause and effect,- - this preferential use being secured by the ownership of material articles employed in the processes in which these expedients are put into effect. The intangible assets capitalize the preferential use of certain facts of human naturehabits, propensities, beliefs, aspirations, necessities - to be dealt with under the psychological laws of human motivation; this

253 In Veblen's idea of blind drift, which is the substance of his arguments involving the absurd, "[h]istory contains no meaning save what humans impart to it." Dugger, supra note 13 , at 1 .

254 "[T] $[$ angible assets, commonly so called, capitalize the processes of production, while intangible assets, so called, capitalize certain expedients and processes of acquisition, not productive of wealth, but affecting only its distribution." Veblen, On the Nature of Capital, supra note 8, at 117; see also STEVE KEEN, DEBUNKING ECONOMICS - REVISED AND EXPANDED EDITION: THE NAKED EMPEROR DETHRONED? 142-57 (2011) (explaining how "capital" should not really be used interchangeably to describe both "a sum of money" and "a collection of machinery," though some economists confusingly do so). 
preferential use being secured by custom, as in the case of old-fashioned good-will, by legal assignment, as in patent or copyright, by ownership of the instruments of production, as in the case of industrial monopolies. ${ }^{255}$

Further, as to the character of a patent right considered as an asset[.] The invention or innovation covered by the patent right is a contribution to the common stock of technological proficiency[.] It may be (immediately) serviceable to the community at large, or it may not; - eg, a cash register, a bank-check punch, a street-car fare register, a burglar-proof safe, and the like are of no immediate service to the community at large, but serve only a pecuniary use to their users[.] But, whether the innovation is useful or not, the patent right, as an asset, has no (immediate) usefulness at large, since its essence is the restriction of the usufruct of the innovation to the patentee[.] Immediately and directly the patent right must be considered a detriment to the community at large, since its purport is to prevent the community from making use of the patented innovation, whatever may be its ulterior beneficial effects or its ethical justification. ${ }^{256}$

Key to these insights is the relationship to the traditional quid pro quo of the patent grant. ${ }^{257}$ Every patent has at least theoretical

255 Veblen, On the Nature of Capital, supra note 8, at 123-24 (footnote omitted) (emphasis added).

${ }^{256} I d$. at $115 \mathrm{n} .1$ (emphasis added). This resembles a Jeffersonian view on the value of patents.

257 Eldred v. Ashcroft, 537 U.S. 186, 223-24 (2002) (discussing the foundation of patent right - and copyright - in a quid pro quo framework); J.E.M. Ag Supply, Inc. v. Pioneer Hi-Bred International, Inc., 534 U. S. 124, 
value as an intangible asset. ${ }^{258}$ This is fundamentally a social (pecuniary) value, as it rests on social norms that give weight to the rule of law establishing exclusionary rights in patents. This is also the basis for the incentive theory on which the U.S. patent laws have rested-rightly or wrongly-from their first enactment. ${ }^{259}$ Public disclosure of an invention is "the price paid for the exclusivity secured" by the patent monopoly given to an inventor. $^{260}$ For instance, in parallel with Veblen's critiques, economist Alfred Marshall distinguished temporally-limited "quasi-rents," associated with patent grants as reward for innovation, from predatory, unearned rents. ${ }^{261}$ Yet the subject

142 (2001) ("The disclosure required by the Patent Act is 'the quid pro quo of the right to exclude."' (quoting Kewanee Oil Co. v. Bicron Corp., 416 U. S. 470, 484 (1974))); Bonito Boats, Inc. v. Thunder Craft Boats, Inc., 489 U. S. 141, 161 (1989) ("the quid pro quo of substantial creative effort required by the federal [patent] statute"); Brenner v. Manson, 383 U.S. 519, 534 (1966) ("The basic quid pro quo ... for granting a patent monopoly is the benefit derived by the public from an invention with substantial utility."); Pennock v. Dialogue, 27 U.S. (2 Pet.) 1, 23 (1829) (If an invention is already commonly known and used when the patent is sought, "there might be sound reason for presuming, that the legislature did not intend to grant an exclusive right," given the absence of a "quid pro quo."); see also Pfaff v. Wells Elecs., Inc., 525 U.S. 55, 63 (1998) (" $[T]$ he patent system represents a carefully crafted bargain that encourages both the creation and the public disclosure of new and useful advances in technology, in return for an exclusive monopoly for a limited period of time."); MySpace, Inc. v. GraphOn Corp., 672 F.3d 1250, 1266 (Fed. Cir. 2012) (Mayer, J., dissenting).

258 This distinction is lost in some economic treatments of patents, or at least not completely articulated. See, e.g., Irwin, supra note 9, at 814, 820 (noting that "economic good" and "social good" are not coextensive as is sometimes assumed).

259 See, e.g., Sears, Roebuck \& Co. v. Stiffel Co., 376 U. S. 225, 229 (1964).

${ }^{260}$ Eldred, 537 U.S. at 216.

261 Hudson, supra note 223; Quasi-rent, WIKIPEDIA, https:// en.wikipedia.org/wiki/Quasi-rent (last updated Aug. 10, 2013). It does bear mentioning here that Veblen was, in general, critical of Alfred Marshall. The basic idea is that although patents are about rent-seeking, the quid pro quo of patent grants balances the inherent rent-seeking aspect against a public benefit 
matter of a given patent claim may or may not relate to tools, real production, and technological knowledge of cause-and-effect. This correlates directly to the question of patent subject matter eligibility and goes to the balance struck by the patent laws between rewarding inventive activity, on the one hand, and conveying creative monopolies, on the other. ${ }^{262}$ Some, like Joseph Schumpeter, tend to assume that the latter always promotes the former, while others, like Veblen, tend to see possible divergences.

It might be said that a patent claim that does not recite a contribution with a sufficient relationship to "technological proficiency" or "usefulness at large" should not be subject matter eligible, because it represents merely a naked pecuniary benefit and therefore is about "getting something for nothing" or a "free lunch." The point, along Veblenian lines, is to identify and limit zero-sum pecuniary rent-seeking. "Any and all greed and selfinterest is obviously not compatible with public interest, only the self-interest which increases rather than diminishes the size of the economic pie." ${ }^{263}$ This is a more economic-centered approach than the "machine-or-transformation" test applied in patent law, ${ }^{264}$ yet also the opposite of the tacit economic rationale applied by some judges to the analysis of patent eligibility today. ${ }^{265}$ All patents are

for a temporally-limited period. Veblen said that discussions of "rent" or "quasi-rent" were "of great theoretical weight." VEBLEN, supra note 20, at 201, n. 6 .

262 David F. Noble, America By Design: ScIEnCE, TeChNOlogy AND THE RISE OF CORPORATE CAPITALISM 84-109 (Knopf 1977).

263 Reinert, supra note 18, at 58, 62 (noting a need to "separate the kind of self-interest which contributes to wealth creation from that which constitutes predatory wealth extraction. In other words productive self-interest or good greed must be separated from bad greed ... . Thorstein Veblen's work was the one making the clearest separation between the human proclivities that produce - respectively - good and bad greed.”).

264 See generally U.S. PATENT \& TRADEMARK OFFICE, MPEP $§ 2106$ (8th ed. Rev. 8, Aug. 2012).

265 Irwin, supra note 9, at 814 ("Today, the standards [for patent eligibility] encompass any product of human action that creates economic value. If 
intangible assets, but when a patent claim fails to extend beyond the essentially social realm of intangible assets and fails to provide a contribution to the common stock of technological proficiency, then subject matter eligibility should be deemed lacking. A patent claim that relates only to intangible assets is a naked grant of economic monopoly power, in a zero-sum sense, without a concomitant contribution to the repeatable human mastery of nature (i.e., applied physics and engineering). ${ }^{266}$

When courts criticize patent claims as being to "abstract ideas" because those claims have only incidental connections to machines, etc., ${ }^{267}$ it often is because the patent applicant or owner

something has value in use or exchange ... it now constitutes patentable subject matter.") (internal citations omitted). In many ways, Irwin's analysis is along Veblenian lines, by criticizing the refusal of neoclassical economics to recognize distinctions between productive and unproductive activities or the endogenous and social nature of economic valuation, and by rejecting the distinction drawn in some economic schools between exchange value and use value. Compare id., with BOURDIEU, supra note 40. The "economic" rationale summarized by Irwin also rejects the Enlightenment ideal that private greed is tolerated only when it promotes the public good, and instead endorses any private gain without consideration of the public good-making such analyses blind to whether the asserted private gain came at the expense of another (a zero-sum result). See Reinert, supra note 18, at 58,62. This is a turn toward what the Lowell Mill Girls' once criticized as the "new spirit of the age: gain wealth, forgetting all but self."

266 This is why Veblen could mention "letters patent" and "letters of marque" in the same breath when discussing the preferential benefits of immaterial wealth. Veblen, On the Nature of Capital, supra note 8, at 113-14; see also Zuege, supra note 64 , at 21 . Veblen drew a distinction between serviceability "at large" and serviceability merely to a user. The "usefulness" of a patent that covers a known process may be tremendous for the patent holder in the self-interested, intangible asset sense, due to the patent holder's ability to levy what amounts to a quasi-extortionate tax on businesses relying on the process (i.e., rent-seeking). But while such a raw transfer of wealth is "useful" to the patent holder accruing the benefits of such a transfer, it is of no use to society writ large, which gains no step forward in repeatable efforts of applied physics and engineering.

267 See, e.g., Dealertrack, Inc. v. Huber, 674 F.3d 1315, 1334 (Fed. Cir. 2012) (citing Bilski v. Kappos, 130 S. Ct. 3218, 3231 (2010); Diamond v. Diehr, 
is merely seeking to surrender a part of the monopoly power that "capitalize[s] the preferential use of certain facts of human naturehabits, propensities, beliefs, aspirations, necessities" (usually the part least profitable to him or her) without tethering him- or herself to any particular "contribution to the common stock of technological proficiency." The patent applicant/owner may be willing to accept a smaller monopoly, but such argument should be deemed irrelevant. The question that should be asked is how the patent applicant or patentee has claimed a contribution to the "common stock of technological proficiency" to justify any monopoly grant at all. ${ }^{268}$ Has a given "inventor" enabled human beings to repeatably achieve a result in the (transcultural) natural world that humans were unable to previously accomplish? ${ }^{269}$ Or has he or she merely found a way to exert influence in a social matrix, possibly by seeking a patent monopoly-however large or small - to reserve an entire field of endeavor to him- or herself? The former can be economically productive, while the latter is invidious and nonproductive. ${ }^{270} \mathrm{~A}$ contribution of a nontechnical

450 U.S. 175, 191 - 92 n.14 (1981)); SiRF Tech., Inc. v. Int'l Trade Comm'n, 601 F.3d 1319, 1333 (Fed. Cir. 2010); Marchand v. Emken, 132 U.S. 195, 199 (1889).

${ }^{268}$ Cf. MySpace, Inc. v. GraphOn Corp., 672 F.3d 1250, 1266 (Fed. Cir. 2012 (Mayer, J., dissenting) ("A patentee does not uphold his end of [the patent system's] 'bargain' if he seeks broad monopoly rights without a concomitant contribution to the existing body of scientific and technical knowledge."). "Technological progress reduces the value of physical capital in place." HUDSON, supra note 10, at 312.

269 See Veblen, supra note 20, at 37 ("The discipline of the machine process ... inculcates a habit of apprehending and explaining facts in terms of material cause and effect.").

270 Even Ronald Coase, from the so-called "freshwater" neo-classical school of economics, had to concede-albeit tucked into a footnote-a very Veblenian point that (for a parallel situation involving broadcast communications licenses), "A waste of resources may result when the criteria used by courts to delimit rights result in resources being employed solely to establish a claim." R. H. Coase, The Federal Communications Commission, 2 J. LAW \& ECONOMICS 1, 27 n.54 (1959). To the extent that Coase attempted to 
and nonproductive disclosure as to business methods or the like should therefore be seen as insufficient to satisfy the quid pro quo of a patent monopoly. Such business method patent claims amount to no more than piling the pecuniary on top of the pecuniary, without crossing over to the realm of nonpecuniary technological proficiency.

\section{Equal Access}

When the U.S. patent system was first established, in the initial constitutional authorization and through its early administration, it represented both a continuance and a divergence from the British patent system on which it was largely based. The constitutional clause "To promote the Progress of Science and useful Arts, by securing for limited Times to Authors and Inventors the exclusive Right to their respective Writings and Discoveries" continued to give inventors (and authors) a central role, ${ }^{271}$ but the United States went further in making its patent system more egalitarian than the system in England. ${ }^{272}$ The early administration of the patent system in the United States made patents available to a much wider set of socioeconomic classes than in England, which had historically tended to preserve upper class privilege through royal grants of

merge institutional economics with marginal analysis, see Herbert Hovenkamp, The Law of Vertical Integration and the Business Firm: 1880-1960, 95 Iowa L. REV. 863, 875 (2010), he was rejecting the basis of Veblen's program.

271 The role of inventors was established in the British Statute of Monopolies of 1624. This has carried through as a bedrock principle of America patent law. Board of Trustees of Leland Stanford Junior Univ. v. Roche Molecular Sys., Inc., 563 U.S. _, No. 09-1159, Slip Op. at *6 (U.S., June 6, 2011) ("Although much in intellectual property law has changed in the 220 years since the first [American] Patent Act, the basic idea that inventors have the right to patent their inventions has not.").

272 It scarcely bears mentioning that the United States was still lacking in egalitarian practices by modern standards, given that slavery was protected, women denied the right to vote, etc. But the trend was toward increasing egalitarianism. 
monopolies. ${ }^{273}$ Moreover, the practice of the "useful arts" was from antiquity through the American revolutionary period viewed as the province of lower classes. ${ }^{274}$ Reciting "useful arts" as a constitutional limitation on patent grants carries a significant social meaning, linking patent monopolies to the "vulgar" workmanlike activities of lower classes. Yet as Veblen later articulated, things like privilege and monopoly (including patent monopolies) are connected to the pecuniary interests of the leisure and business classes - those who typically see themselves as above the sort of "workmanship" associated with the useful arts.

In these respects, the American patent system represented a relatively egalitarian convergence of upper and lower class interests. ${ }^{275}$ Veblen's discussion of intangible asset capitalization

273 B. Zorina Khan, Intellectual Property and Economic Development: Lessons from American and European History, BRITISH COMM. INT. PROP. RIGHTS (London, 2002), available at http://network.idlo.int/Publications/ Khan\%20Z.\%20-

$\% 20$ Intellectual\%20Property\%20and\%20Economic\%20Development,\%20Less ons\%20from\%20History.pdf; B. Zorina Khan \& Kenneth L. Sokoloff, Institutions and Technological Growth During Early Economic Development: Evidence from the Great Inventors of the United States, 94 AM. ECON. REV. 395, 1790-1930 (2004) (noting, inter alia, that early U.S. patents were less restricted to inventors with "elite" backgrounds than in Britain during the same era, and early U.S. patent system fees were a fraction of those in Britain); see also Morgan Sherwood, The Origins and Development of the American Patent System: How Well Do the Idea and Implementation of Patents Mesh With the Aims of a Democratic Society?, 71 AM. SCIENTIST 500 (1983); Irwin, supra note 9, at 796-97.

274 Leo Marx, Technology: The Emergence of a Hazardous Concept, 51 TECH. \& CulTuRE 561, 573 (2010).

275 Chris Dent has written about how the British Statute of Monopolies represented a political compromise between essentially different class interests, and was emblematic of the transition from feudalism to capitalism. In this context, the Statute of Monopolies eliminated patents in areas other than for invention. Chris Dent, 'Generally Inconvenient': The 1624 Statute of Monopolies as Political Compromise, 33 Melbourne U. L. ReV. 415 (2009); see also MAX LOUIS KENT, THE BRITISH ENLIGHTENMENT AND THE SPIRIT OF THE INDUSTRIAL REVOlution: THE SOCIETY FOR THE ENCOURAGEMENT OF 
through patents implicitly recognizes that convergence. ${ }^{276}$ Yet, recent expansions of patent subject matter eligibility threaten to erase this contextual grounding.

By opening patentability to the domains of invidious pecuniary interests-like those of the FIRE sector-the strict connection to the lowly "useful arts" is broken and the egalitarian class convergence embedded in the U.S. patent system is denigrated. This harkens back to the pre-Statue of Monopolies British system that tended toward monopoly grants to protect the privileges of vested interests. ${ }^{277}$ The seeming regression to the economic conditions of "post-industrial feudalism" discussed above carries with it an urge to shift social institutions as well, pushing patent law institutions back the pre-Enlightenment era when they encompassed naked grants of privilege, unmoored from the bounds of the useful arts. ${ }^{278}$ While criticizing the underlying views that rely on a labor theory of value, Veblen discussed how the Western European (and specifically English) view of ownership, which had

ARTS, MANUFACTURES AND COMMERCE (1754-1815) 215-22 (2008). In the Veblenian view, the ways in which feudal privileges were both preserved and limited as evidenced by the political compromise of the Statute of Monopolies, and then carried over in part to American patent law, is of particular interest.

276 Veblen very much wrote about social shifts in balances of power, and was in some respects lamenting how egalitarian ideals from the Enlightenment era were being lost in America at the dawn of the Twentieth Century.

277 Thomas Ewing, The American Patent System, in Centennial Celebration of the American Patent System: Being a Complete SUMMARY OF ALl THE SPEECHES \& DATA OF THE BANQUET \& PROCEEDINGS OF THE ONE HUNDREDTH ANNIVERSARY OF THE AMERICAN PATENT SYSTEM 6 (U.S. Gov. Printing Office, 1937); Dent, supra note 275, at 443 (noting that patents were sometimes granted to someone other than the inventor); Allen Nard \& Andrew P. Morriss, Constitutionalizing Patents: From Venice to Philadelphia, 2 REV. L. \& ECON. 223, 258-90 (2006).

278 This is part of what Veblen means when he distinguishes the causal sequence of technology from the evolution of pecuniary institutions - the latter can ebb and flow while technological knowledge doesn't. For a discussion of the influence of Enlightenment thought on the question of patentability, see Irwin, supra note 9, at 785-96. 
carried forward to the modern age, first arose during the era of "handicraft and petty trade" from the theories of people like John Locke, and dealt with ownership claims arising from productive work. ${ }^{279}$ This supplanted a view from medieval (feudal) times when ownership was premised on social standing (the divine rights of kings, hereditary privilege, etc.). ${ }^{280}$ Where Veblen went beyond Enlightenment thinkers like Locke, was in his exposition of the industrial-pecuniary dichotomy to more clearly distinguish productive activity from unproductive activity during a more modern age of mechanized industry, and in rejecting an economic value theory premised exclusively on one factor like labor. In present circumstances, opening patent eligibility to business methods and the like allows pecuniary interests to exert further control over the economy without interfacing with the lowly realm of the useful arts, turning the conception of patent rights back to the period before the Enlightenment and before the Statute of Monopolies set the stage for Enlightenment thinkers like Locke.

VIII. EXPLORING SOCIAL ASPECTS FOR PATENT ELIGIBILITY ANALYSIS IN A VEBLENIAN FRAMEWORK

\section{A. The Nature of Pecuniary Activities}

If a Veblenian dichotomy is to be applied to patent subject matter eligibility questions, it is important to understand the invidious social nature of pecuniary activities. Veblen saw financial securities instruments and real estate as the two chief examples (though certainly not the only examples) of pecuniary business activities that lacked serviceability at large. ${ }^{281}$

279 VEBLEN, supra note 20, at 71-82.

${ }^{280}$ Id. at $75-77$.

$281 \mathrm{He}$ also frequently mentioned advertising and sales as privately benefitting business without corresponding serviceability at large. Id. at 52-55 ("The great end of consistent advertising is to establish such differential monopolies resting on popular conviction."). Compare id., with Graeber, supra note 57. Moreover, he saw gambling and games of chance as also lacking 
Of these strictly economic activities that are lucrative without necessarily being serviceable to the community, the greater part are to be classed as "business." Perhaps the largest and most obvious illustration of these legitimate business employments is afforded by the speculator in securities. By way of further illustration may be mentioned the extensive and varied business of realestate men (land-agents) engaged in the purchase and sale of property for speculative gain or for a commission; so, also, the closely related business of promoters and boomers of other than real-estate ventures; as also attorneys, brokers, bankers, and the like, although the work of these latter will more obviously bear interpretation in terms of social serviceability. The traffic of these business men shades off insensibly from that of the bona fide speculator who has no ulterior end of industrial efficiency to serve, to that of the captain of industry or entrepreneur as conventionally set forth in the economic manuals.

The characteristic in which these business employments resemble one another, and in which they differ from the mechanical occupations as well as from other non-economic employments, is that they are concerned primarily with the phenomena of value - with exchange or market values and with purchase and sale-and only indirectly and secondarily, if at all, with mechanical processes. What holds the interest and guides and shifts the attention of men within these employments is the main chance. These activities begin and end within

serviceability and fundamentally based on predatory instincts rather than scientific matter-of-fact knowledge. See generally VEBLEN, supra note 10, at 276-78, 282. 
what may broadly be called "the higgling of the market". Of the industrial employments, in the stricter sense, it may be said, on the other hand, that they begin and end outside the higgling of the market. Their proximate aim and effect is the shaping and guiding of material things and processes. Broadly, they may be said to be primarily occupied with the phenomena of material serviceability, rather than with those of exchange value. They are taken up with the phenomena which make the subject matter of Physics and the other material sciences. ${ }^{282}$

Early on Veblen drew this distinction between invidious "pecuniary" activities, which tended to function in the realm of pricing and socially contingent value judgments, from those of industry, which were noninvidious and matter-of-fact issues of efficiency, and he carried the idea forward through his later work. Indeed, he used the term "price system" to refer generally to the endogenous (and socially contingent) nature of economic value determinations, as distinct from the practical and useful qualities of workmanlike engineering activity. ${ }^{283}$

First, take "inventions" for financial securities operations and practices. These are generally a product of confidence and euphoria, and are tied to particular social contexts. Economist John Kenneth Galbraith (a noted adherent of Veblen's theories) later said that "financial operations do not lend themselves to innovation." 284 Rather, "[a]ll financial innovation involves, in one

282 Thorstein Veblen, Industrial and Pecuniary Employments, 2 PUB. AM. ECON. Ass'N, 190, 204-05 (1901), available at https://archive.org/details/jstor2485814.

283 See generally ThORStein Veblen, The EngineERs AND the PRICE SYSTEM (1921).

284 John KENNETH Galbraith, A SHORT History OF FinANCIAL EUPHORIA 19 (Penguin Books 1993); see also VEBLEN, supra note 20, at 103- 
form or another, the creation of debt secured in greater or lesser adequacy by real assets." 285 Finance often revolves around "speculative" activities, which involve "changing prices of goods which have already been produced, rather than . . . the production of new goods and services." 286 In this way recently reported "productivity gains" in the U.S. economy have often really "involved control of government and cultural attitudes, not technology as most people understand the term."287 The highvolume, nearly instantaneous computerized securities trading undertaken by financial traders known as "quants," 288 for instance, tends to look much like a game of misleading competitors (especially other quants) in intention in order to make speculative profits off zero-sum arbitrage. ${ }^{289}$ In some ways, the "quants" simply deployed a computerized Keynesian beauty contest, the classic example given by economist John Maynard Keynes, of economic activities being less about objective fact or individual opinion than of gauging public perceptions within a social

04, (“[A]11 advances made by banking houses or by other creditors in a like case, ... all these 'advances' go to increase the 'capital' of which business men have the disposal; but for the material purposes of industry, taken in the aggregate, they are purely fictitious items. ... Funds of whatever character are a pecuniary fact, not an industrial one; they serve the distribution of the control of industry only, not its materially productive work.").

285 Galbraith, supra note 284; see also Michael Hudson, Wall Street's Power Grab, COUNTERPUNCH (Jan. 19, 2010), http://www.counterpunch.org/ 2010/01/19/wall-street-s-power-grab. Similar views appear regularly in the popular press. E.g., Matt Taibbi, Looting the Pension Funds, ROLLING STONE (Sept. 26, 2013), http://www.rollingstone.com/politics/news/looting-thepension-funds-20130926.

${ }^{286}$ Reinert, supra note 18 , at 57, 66.

287 Schaefer, supra note 58 (quoting Michael Hudson).

288 For an overview of "quants," see SCOTt PATtERSON, THE QUANTS (2010).

289 Pam Martens, Inside the Flash Crash Report, COUNTERPUNCH (Oct. 4, 2010), http://www.counterpunch.org/2010/10/04/inside-the-flash-crash-report. 
context. ${ }^{290}$ Taken to the absurd, this is very much like the battle of wits between Vizzini (played by Wallace Shawn) and The Man in Black (played by Cary Elwes) in the movie The Princess Bride in which two men compete to the death as one tries to select a wine chalice to drink from that is free from poison-noting of course Vizzini's attempt to deceive the Man in Black with distraction and a surreptitious maneuver. ${ }^{291}$

Another, closely related aspect is to avoid regulation, that is, to circumvent legal restrictions on capital flow. ${ }^{292}$ In essence, "financial innovation" for financial instruments and trading can be generalized as variations in leverage in such instruments and transaction, and in the manipulation of balance sheets through accounting practices. While these may admit a certain accomplishment and personal skill, it is a game of confidence. And confidence games are social ones. Persons achieving such financial accomplishments have certainly expended effort to do so, but it remains difficult to see how such effort bears any relationship to the ways productive innovation has been recognized in traditional

290 JOHN MAYNARD KEYNES, GENERAL THEORY OF EMPLOYMENT INTEREST AND MONEY (1936); see also Keynesian Beauty Contest, WIKIPEDIA, https:// en.wikipedia.org/wiki/Keynesian_beauty_contest (last updated June 7, 2013).

${ }^{291}$ THE PRINCESS BRIDE (Twentieth Century Fox 1987).

292 HARVEY, supra note 67, at 99-100 ("One of the purposes of this innovation wave was to avoid regulation and to create new arenas in which the capital surpluses could be profitably deployed in 'free' (that is, unregulated) markets without constraint."); James K. Galbraith, The Final Death (and Next Life) of Keynes, Keynote Lecture to 5th Annual "Dijon" Conference on Post Keynesian Economics, Copenhagen, Denmark (May 13, 2011), http:// www.zcommunications.org/the-final-death-and-next-life-of-keynes-by-james-kgalbraith (discussing, in the context of the work of Thorstein Veblen and John Commons, the use of technology by finance "for the purpose of breaking down and evading the law" and that volumes of recent financial vehicles are hypervulnerable to fraud). The argument that patents that restrict this sort of activity might be to the public benefit is not pursued here. See generally Christopher A. Cotropia \& James Gibson, The Upside of Intellectual Property's Downside, 57 UCLA L. REV. 921 (2010). 
industrial sectors. ${ }^{293}$ These take on something more like factors of sociopolitical action rather than of technological progress, because society at large stands to gain nothing at all.

Next, take real estate. The domain of real estate is really about legal rights to territory, and residential real estate at least is generally a matter of formalities and transactions in establishing claims to particular space. Investment in real estate tends toward being speculative, and can divert the use of loan credit away from productive employment in industry. ${ }^{294}$

The key to understand Veblen and indeed, the Reform Era, is to analyze land rent, and how urban real estate speculation was becoming not only the fastest way to get rich, but also the major customer of banking and high finance. ... Veblen became justly famous for describing small towns (and by logical extension, big cities) as real estate promotion projects, trying to get the proverbial "something for nothing." He described America's rapid urbanization as a great real estate game-what today is called a zero-sum game in which one party's winnings are another's loss. ${ }^{295}$

Commenting on the sale of Veblen's former home, Professor Sidney Plotkin noted, "He understood that real estate was an

293 Indeed, most statistics compiled on research and development and innovation do not include financial products. Robert M. Hunt, Ten Years After: What Are the Effects of Business Method Patents in Financial Services?, FEDERAL RESERVE BANK OF PHILADELPHIA BUSINESS REVIEW 21, 27 (3rd Quarter 2008), available at http://www.phil.frb.org/research-and-data/ publications/business-review/2008/q3/brq308_effects-of-business-methodpatents.pdf.

294 See, e.g., VEBLEN, supra note 20, at 102-03.

295 Michael Hudson, The Social Economics of Thorstein Veblen, EH.NET (Oct. 23, 2012), available at http://michael-hudson.com/2012/10/the-socialeconomics-of-thorstein-veblen/; see also VEBLEN, supra note 20, at 64-65 
exercise in inflated values that could vanish in a split second." 296 Pierre Bourdieu's landmark study of the French single-family real estate market later demonstrated how real estate transactions were influenced by a structural field, that is to say a "space of possibles" open to economic actors. ${ }^{297}$ Much as Veblen discussed "vested interests," Bourdieu concludes that "[ $\mathrm{t}]$ he forces of the field orient the dominant towards strategies whose end is the perpetuation or reinforcement of their domination."298 Again, like Veblen, Bourdieu noted that "technological capital" plays a crucial role, but only when combined with other forms of capital. ${ }^{299}$ It is those nontechnological aspects that come into play when considering patenting related to real estate-principally the patenting of methods for conducting real estate transactions and handling associated securities. Bourdieu emphasized how the nature of single-family home sales revolved around marketing and sales efforts intended to convince buyers to live further from city centers than they would otherwise choose, to feel as if they have purchased a "traditionally built" home that in fact is made with "industrial" pre-fab methods, and to commit to a purchase above resale value.

${ }^{296}$ Patricia Leight Brown, An Inconspicuous Consumption Yields, at Last, to Market Forces, N.Y. TiMES (Oct. 9, 2004), http://www.nytimes.com/2004/10/ 09/national/09menlo.html.

${ }^{297}$ BouRdiEU, supra note 40, at 194-195; see also Anna Leander, Pierre Bourdieu on Economics, 8 REV. INT'L POL. ECON. 344, 347 (2001) ("[I]t is precisely the formation of the rules of the game, of interests and of identities that gives shape to social identity."). Bourdieu's economic field theory is akin to Einstein's general theory of relativity in physics, in so much as the specific weapons or strengths of economic entities in a structural field exert weight in that field apart from any direct intervention or manipulation by that entity, much like the way gravity is explained by Einstein not as a force acting upon discrete bodies as in Newtonian physics but as a characteristic of the curvature of spacetime as a result of the physical reality of space-time being represented as forcefree continuous functions of independent variables. See Albert Einstein, On the Generalized Theory of Gravitation, 182 SCI. AM. 13, 15-16 (April 1950), reprinted in IDEAS AND OPINIONS 341-56 (Bonanza 1988).

${ }^{298}$ BOURDIEU, supra note 40, at 202.

${ }^{299} I d$. at 203. 
Bourdieu also emphasized how the nature of single-family home sales revolved around cultural and legal contexts such as government support for private mortgage loans over public housing. ${ }^{300}$ Here it might also be worth considering a character from novelist Sinclair Lewis: "[h] is name was George F. Babbitt. He was forty-six years old now, in April, 1920, and he made nothing in particular, neither butter nor shoes nor poetry, but he was nimble in the calling of selling houses for more than people could afford to pay." "301 Patents involving real estate are likely to revolve around customs that govern transaction protocols, in a constant interaction with the social peculiarities of the agents involved in sales, particularly the "effect of trusting closeness or hostile aloofness." 302 For instance, adding computers to the transactions merely increases the aloofness. These are social and pecuniary activities, part of the "higgling of the market," and bear no relationship to mastering the cause-and-effect nature of the physical world.

Allowing patents on what amount to social relations is problematic. While there is much discussion of whether business methods should be patent-eligible, a more pointed question is whether claims drawn to a business model, unmoored from technological constraints, should be patent-eligible. Business models fall into the realm of social relations, and perhaps can be analyzed as such more readily and objectively than assessing how substantially or meaningfully the model relates to tangible objects like general-purpose computers. This question is important though, because the latitude to seek claims to a given invention at any level of abstraction means that nearly any invention can be claimed so broadly as to constitute a business model, even in situations where more narrowly drawn claims to the same invention would no longer consist only of the business model (as the asserted point of

\footnotetext{
${ }^{300}$ See generally id.

301 SinCLAIR LEWIS, BABBiT 6 (Modern Library 2002) (1922).

${ }^{302}$ BOURDIEU supra note 85 , at 175 .
} 
novelty). ${ }^{303}$ Business models do not solve technical problems, but only dictate who controls (and therefore who benefits from) transactions and associated wealth.

Many of these concerns seem like the same ones underlying judicial statements in the Prometheus and Flook cases regarding pre-solution and post-solution activities. In the Veblenian view, the judicial term "pre-solution activities" "304 is best viewed as a euphemism for protecting a subject matter space in which inventive activity is planned, and in which the planned inventive activity may or may not later occur or succeed. ${ }^{305}$ That term can be seen to describe overbroad functional or genus language in patent claims, like that of Samuel Morse in O'Reilly v. Morse, ${ }^{306}$ in which protection is prospectively sought over possible and unrealized future invention by reciting only the desired result without reference to the technical mechanism(s) actually invented. ${ }^{307}$

303 See, e.g., Classen Immunotherapies, Inc. v. Biogen IDEC, 659 F.3d 1057, 1078, 1080 (Fed. Cir. 2011) (Moore, J., dissenting). Judge Moore stated quite well how Classen could have claimed any number of specific contributions but instead sought what amounts to a monopoly on any study of a particular phenomenon. This is quite close to saying that Classen was claiming what amounted to a business model for the use of medical phenomena.

304 Mayo Collaborative Servs. v. Prometheus Labs., Inc., 132 S.Ct. 1289 (2012).

305 According to Veblen, "[b]usiness conceptions and methods antedate the machine process." L.A. O'Donnell, Rationalism, Capitalism and the Entrepreneur: The Views of Veblen and Schumpeter, 5 HISTORY OF POLITICAL ECONOMY 199 (1973), reprinted in 3 THORSTEIN VEBLEN: CRITICAL ASSESSMENTS 219 (John Cunningham Wood ed., 1993).

306 O'Reilly v. Morse, 56 U.S 62, 68 (1852). Contra Tilghman v. Proctor, 102 U.S. 707, 710, 720-22 (1880) (noting that the "patent is for a process, and not for any specific mechanism for carrying such process into effect," but further noting that different processes for achieving the effect claimed by Tilghman were known in the prior art and that Tilghman himself disclosed an unclaimed lower temperature variation, in essence acknowledging that the claim language at issue was not preemptive).

307 O'Reilly, 56 U.S at 113 ("“[W]hile he shuts the door against inventions of other persons, the patentee would be able to avail himself of new discoveries 
Further, the judicial term "postsolution activity"308 can be seen as another euphemism for nontechnological activities that lack a sufficient connection to a technological process or artifact, by instead being after-the-fact attempts to privately direct or sequester the saleable benefits of prior technological achievement. ${ }^{309}$ The term "postsolution activity" often precisely describes patent claims directed to business activities that make arbitrary and passing reference to known technologies, while making a further "contribution" only to means for socially allocating value, such as through a new business model that relates purely to the saleability of pre-existing invention or technology. ${ }^{310}$

in the properties and powers of electro-magnetism which scientific men might bring to light . ..."). In short, this is an instance that the technical causal mechanism that allows the result to be repeatably achieved must be claimed, not merely disclosed.

${ }^{308}$ Parker v. Flook, 437 U. S. 584, 590 (1978); Diamond v. Diehr, 450 U.S. 174, 191-92 (1981).

309 "By the sale of the output the business man in industry 'realizes' his gains. To 'realize' means to convert salable goods into money values. The sale is the last step in the process and the end of the business man's endeavor. When he has disposed of the output, and so has converted his holdings of consumable articles into money values, his gains are as nearly secure and definitive as the circumstances of modern life admit. It is in terms of price that he keeps his accounts, and in the same terms he computes his output of products. The vital point of production with him is the vendibility of the output, its convertibility into money values, not its serviceability for the needs of mankind. A modicum of serviceability, for some purpose or other, the output must have if it is to be salable." VEBLEN, supra note 20, at 30.

${ }^{310}$ As an example, this could involve the inventor of a business method recognizing that a customer might change its practices if doing so is tied to buying a new computer system, even if the customer could have readily changed its practices without the purchase of a computer system. In other words, the "tangible" machine - the computer system - is something tied to saleability (triggering the customer's desire to purchase something) rather than to changes in practices alleged to be more efficient or to solve a problem. In terms of productivity, the computer system is a red herring. For that matter, the underlying practices may not relate to productivity either, but may be driven entirely by a desire to work employees harder and longer, increase power and control of management over labor, etc. 


\section{B. Example Claim Analyses}

Some patent-specific examples may clarify these Veblenian distinctions between productive and unproductive activities. For instance, an inventor may devise a new method for operating an existing machine, say, by operating different components at different speeds to achieve higher throughput with fewer defects. Such a process-oriented achievement puts forth no new structure or machine, but does enhance economic surplus through the manner of using such a machine. This seems like a patent-eligible contribution. The same might be said for devising a new sequence for chemically separating compounds more efficiently. Such an advance relates to the technology involved in the application of chemical principles to reduce material or energy inputs, and seems patent-eligible. ${ }^{311}$ Pure "business methods" are a rather easy case from a Veblenian perspective - they would simply be categorically excluded from patentability. But business methods can appear in unlikely places, as explained below. Software also presents a particularly thorny problem because it can easily have both technological and pecuniary functions in varying degrees. ${ }^{312}$ But the abstraction problem encountered with software patents ${ }^{313}$ can be assessed in a more practical manner with reference to the Veblen dichotomy, which can allow assessment of the tipping point where high levels of abstraction relinquish a connection to productive industrial activity leaving only unproductive pecuniary activity. Let us turn to a few more concrete examples of patent

311 See, e.g., Tilghman, 102 U.S. 707, 710 (1880) (finding a process for separating fat patentable).

312 Jaron Lanier, in his philosophically muddled way, lamented that social media software had allowed influence to overtake innovation, which was something of a warmed-over Veblenian argument. JARON LANIER, YOU ARE NOT A GADGET: A MANIFESTO (2010).

313 See, e.g., JAMES BESSEN \& MichaEl J. MeUruR, PATENT FAILURE: How JudGES, BUREAUCRATS, AND LAWYERS PUT InNOVATORS AT RISK (2009); Mark A. Lemley \& Julie E. Cohen, Patent Scope and Innovation in the Software Industry, 89 CAL. L. REV. 1, 47-50 (2001). 
claim language to illustrate how the Veblen dichotomy might be applied to the question of patent eligibility.

For instance, DealerTrack involved U.S. Patent No. 6,292,788 (filed Dec. 3, 1998) ("the '788 Patent"), of which independent claim 1 is representative: ${ }^{314}$

1. A method of creating a real estate investment instrument adapted for performing tax-deferred exchanges comprising: aggregating real property to form a real estate portfolio;

encumbering the property in the real estate portfolio with a master agreement; and

creating a plurality of deedshares by dividing title in the real estate portfolio into a plurality of tenant-in-common deeds of at least one predetermined denomination, each of the plurality of deedshares subject to a provision in the master agreement for reaggregating the plurality of tenant-incommon deeds after a specified interval.

From the Veblenian perspective, claim 1 of the '788 Patent is clearly directed to pecuniary activities that hinge upon social constructs of tax laws, title to real property, and speculative investment, and therefore should not be patentable. ${ }^{315}$ This is

${ }^{314}$ Dealertrack, Inc. v. Huber, 674 F.3d 1315, 1315 (Fed. Cir. 2012).

${ }^{315}$ U.S. Patent No. 6,292,788 col. 12 1. 52-64 (filed Dec. 3, 1998). Another example would be claim 1 of U.S. Patent No. 7,584,167 col. $231.8-16$ (filed June 22, 2004), ("the '167 Patent"), which claims " 1 . A real estate disclosure reporting method comprising the steps of: compiling a plurality of items of disclosure; relating said items of disclosure according to a plurality of condition categories; researching a particular property to determine a plurality of known ones of said items of disclosure; and disclosing said known ones according to said condition categories." The '167 patent was originally classified in class/ subclass 707/1, "for computerized data processing systems and corresponding methods for the retrieval of records stored in a database or as computer files." 
consistent with the Federal Circuit's holding when considering the claim:

In Bilski II, the Supreme Court explained that the dependent claims were not patent eligible though they "limit[ed] an abstract idea to one field of use or add[ed] token postsolution components." 130 S. Ct. at 3231. See also Diehr, 450 U.S. at 192 n.14 ("A mathematical formula does not suddenly become patentable subject matter simply by having the applicant acquiesce to limiting the reach of the patent for the formula to a particular technological use.").

The restriction here is precisely the kind of limitation held to be insufficient to confer patent eligibility in Bilski II. The notion of using a clearinghouse generally and using a clearinghouse specifically to apply for car loans, like the relationship between hedging and hedging in the energy market in Bilski II, is of no consequence without more. See Diehr, 450 U.S. at 191 (noting that the principle that a mathematical formula "is not accorded the protection of our patent laws ... cannot be circumvented by attempting to limit the use of the formula to a particular technological environment" 316

While such a claim seems to fail the machine-or-transformation test, and to primarily relate to what could be considered purely mental steps, it also has meaning only in a pecuniary and social sense, because it is premised on legal (or, more broadly, social) obligations associated with real estate transactions rather than productive efficiency gains associated with technological cumulative causation. For those reasons, claim 1 of the ' 167 patent would seem non-patenteligible from a Veblenian perspective.

${ }^{316}$ Dealertrack, 674 F.3d at 1334 (emphasis added). 
From a Veblenian perspective, this is a bit like saying that claims to more narrowly circumscribed pecuniary activitiesabstract ideas limited to a particular industry or technological environment-are still directed to pecuniary activities, and therefore lack a sufficient connection to a technological contribution to justify patent eligibility. ${ }^{317}$ A claim like that in DealerTrack disrupts the quid pro quo of the patent grant and amounts to just a naked grant of rent-seeking monopoly without contributing to production.

A similar example is U.S. Patent Application Pub. No. 2007/0288360 (filed Apr. 5, 2007) ("the '360 Application"), of which independent claim 1 is representative:

1. An interface system for matching a position with an applicant based on credit information, comprising:

a credit user entry module that allows a credit user to define the position and enter a position grade associated with the position;

an applicant entry module that allows the applicant to enter applicant information;

a credit bureau module that generates an applicant grade based on the applicant information and credit information stored in a credit bureau database;

a decision module for comparing the position grade with the applicant grade to determine whether the applicant is qualified for the position; and

\footnotetext{
${ }^{317}$ It is in relation to the notion of the supposed quid pro quo of the patent bargain where Veblen discusses the underlying policy of granting any patent, rhetorically asking, "whatever may be its ulterior beneficial effects or its ethical justification." Veblen, On the Nature of Capital, supra note 8, at 115-16 n.1.
} 
a notification module for notifying the credit user and the applicant whether the applicant is qualified for the position.

Although not explicitly discussed by the '360 Application, a key goal of the claimed system is to provide an intermediary in such a way as to avoid regulatory burdens that limit access to credit information and credit scores (themselves a purely social creation). ${ }^{318}$ Claim 1 of the '360 Application does not delimit itself to technological improvements in terms of labor, materials or energy savings, but instead focuses on the highly abstract forms of interfaces that provide a socially acceptable platform for regulatory avoidance (specifically in relation to credit access). ${ }^{319}$ Perhaps the unclaimed specifics of the "decision module" or "notification module" would present a technological advance, but the claim is written too abstractly to capture any such alleged technological contribution. Although during prosecution of the '360 Application an examiner issued rejections alleging the claims impermissibly recited software per $s e,{ }^{320}$ the Veblenian perspective would not view the issue in terms of technicalities of form like the recitation of software versus hardware (there would be no categorical ban of software patentability). Instead, the Veblenian approach would look at claim 1 of the '360 Application as a merely pecuniary system to avoid regulation and mediate trust, and therefore would say claim 1 should not be patent-eligible because it is not directed to a productive contribution to an underlying technical problem.

Further examples can be found in less conspicuous fields. For instance, U.S. Patent Application Publication Number 2013/0068890 (filed Sept. 20, 2011) ("the '890 Application"),

318 See, e.g., Fair and Accurate Credit Transactions Act of 2003, Pub. L. 108-159, 117 STAT. 1952 (2003).

${ }^{319}$ U.S. Patent Application Pub. No. US 2007/0288360 A1 cl. 1 (filed Apr. $5,2007)$.

${ }^{320}$ Non-Final Rejection, U.S. Patent Application Pub. No. 2007/0288360 (filed Apr. 5, 2007), at 3, June 23, 2011. 
entitled "Dual Boarding System for Aircraft," published March 21, 2013 and assigned to The Boeing Company, includes the following independent claim:

1. A method for boarding an aircraft, the method comprising:

lining up passengers in a first line and a second line relative to a doorway for the aircraft; and

controlling a flow of the passengers in the first line and the second line through the doorway and a corridor connecting the doorway to an interior of the aircraft in which the flow of the passengers passes through a number of spaces in the corridor in which the number of spaces is reserved for a number of crew members during an emergency operation in which the passengers exit the aircraft.

The '890 Application was classified upon publication in U.S. Class/Subclass 244/137.2, for "Aeronautics and Astronautics," "device or arrangement wherein a living being may be taken aboard or removed from the aircraft," "for aircraft structure designed to improve the efficiency of transporting passengers, absent detail or arrangement for loading, or unloading or discharge thereof." 321 However, despite the technical-sounding classification and the fact that aircraft construction and design can be productive, the actual language of claim 1 of the ' 890 Application as published is that of a business method. ${ }^{322}$ Disregarding whatever may be disclosed or claimed elsewhere in the application; claim 1 does not

${ }^{321}$ USPTO, Manual of PATENT Classification, http://www.uspto.gov/ web/patents/classification/uspc244/defs244.htm\#C244S137200 (last visited Sept. 24, 2013). Subclass 137.2. of class 244 appears to have only existed for about a decade.

${ }^{322}$ U.S. Patent Application Pub. No. US 2013/0068890 A1 cl. 1 (filed Sept. 20, 2011). 
contain any reference to the solution of a technical problem. ${ }^{323}$ Rather, the claim is written so as to address only a business model applicable to an effect or result in airline operations, and to be preemptive of any technical apparatuses that might be used in service of a two-line passenger boarding business model. ${ }^{324}$ Claim 1 of the '890 Application highlights how a company (Boeing) engaged in actual industrial processes and technological development can still present claims in patent applications directed to pecuniary business models rather than to matter-of-fact industrial solutions to technical problems. In the Veblenian view, claim 1 of the '890 application would not be patent-eligible, because the claim language is not tied to any particularized contribution to technical proficiency.

Another example is U.S. Patent No. 7,080,019 (filed Mar. 4, 2001) ("the '019 Patent"), directed to a "ride share contact system." Independent claim 1 recites in part: ${ }^{325}$

1. A method for enabling contact among travelers with similar travel plans, comprising: soliciting available travel plans from a multitude of Posting travelers, quantitatively characterizing each of said available travel plans' origins and destinations by their numerical latitudes and longitudes, posting said quantitatively characterized available plans to a data base, . . . soliciting a desired travel plan from a Browsing traveler, ... . whereby said Browsing travelers can exercise

323 Id. ("[T] he flow of the passengers passes through a number of spaces in the corridor in which the number of spaces is reserved for a number of crew members during an emergency operation in which the passengers exit the aircraft" seems like an attempt to distinguish cargo planes (such as military transport planes) with large aft doors clearly large enough to fit two passengers, side-by-side).

324 Id.

325 U.S. Patent No. 7,080,019 col. 11-12 (filed Mar. 4, 2001). 
explicit control over said final choice process, and are not constrained to accept the putative optimal choice of said ordering according to said rank.

Although there is a considerable amount of verbiage in claim 1 of the '019 Patent, that claim is directed to managing (potential) customer/user expectations and making social and business judgments as to the types of information that such customers/users would want to see, rather than solving any technological hurdle associated with scarcity of materials, energy and/or labor. ${ }^{326}$ Therefore, from the Veblenian perspective, claim 1 of the ' 019 Patent would seem unpatentable as being directed only to a nonproductive pecuniary endeavor.

In contrast, though still in a situation somewhat comparable to that of the '019 Patent, U.S. Patent No. 8,531,954 (filed May 31, 2007) ("the '954 Patent") is directed to a "system and method for handling reservation requests with a connection admission control engine." Claim 1 of the '954 patent recites:

1. A method for handling reservation requests, the method comprising:

receiving network performance information, utilization information, and capacity information associated with a data stream or connections, the network performance information and utilization information is enabled to be received through one or more performance information packet (PIP) data packets and a state machine tracking the

${ }^{326}$ Id.; see also Darwin Bond-Graham, Sharing Rides, Hording Profits, COUNTERPUNCH (Oct. 18, 2013), http://www.counterpunch.org/2013/10/18/ sharing-rides-hording-profits (questioning the characterization of ride sharing software as "disruptive" technology and noting how ride sharing business models seek social ends of avoiding regulation, avoiding taxes and fees that support public infrastructure, and, more generally, externalizing costs onto predominantly low-income users). 
utilization information and the capacity information, wherein the PIP data packets and the state machine cumulatively update the network performance information, utilization information, and capacity information for each node between and including endpoints of the data stream including customer equipment, wherein the network performance information, utilization information, and capacity information include a plurality of indicators for each node, and wherein each of the plurality of indicators are compared against thresholds to determine a status of each node;

determining available bandwidth in response to the network performance information, utilization information, and capacity information that are cumulatively updated for the data stream or connections utilizing the PIP data packets and the state machine; responding to a plurality of reservation requests in response to the status of each node and the determined available bandwidth determined utilizing the PIP data packets and state machine;

adjusting a frequency the one or more PIP data packets sent through a portion of the communications network in response to determining the portion is experiencing a problem; and 
rerouting the one or more PIP data packets to avoid a failed portion of the communications network. ${ }^{327}$

Such a claim seems patent-eligible, from the Veblenian perspective, because the claimed invention relates to the use of scarce computing (and perhaps energy) resources, as well as specific and detailed methodologies that are tied to a technical problem associated with resource scarcity (within communication networks).

Furthermore, a software-based method that changes the way a computer operates to achieve new computing powers, such as to better render pixels in an image, would seem patentable. In just such a case, the Federal Circuit found such claims to be patenteligible. In Research Corp. Technologies, Inc. v. Microsoft Corp. the court assessed claim 1 of U.S. Patent No. 5,341,228 (filed Dec. 3, 1991) ("the '228 Patent"), which recites:

1. A method for the halftoning of color images, comprising the steps of utilizing, in turn, a pixel-bypixel comparison of each of a plurality of color planes of said color image against a blue noise mask in which the blue noise mask is comprised of a random non-deterministic, non-white noise single valued function which is designed to provide visually pleasing dot profiles when thresholded at any level of said color images, wherein a plurality of blue noise masks are separately utilized to perform said pixel-by-pixel comparison and in which at least one of said blue noise masks has its pixels shifted by at least one pixel prior to performing said pixel-by-pixel comparison. ${ }^{328}$

${ }^{327}$ U.S. Patent No. 8,531,954 col. 102 1. 17-51 (filed May 31, 2007).

${ }^{328}$ Research Corp. Techs., Inc. v. Microsoft Corp., 627 F.3d 859, 869 (Fed. Cir. 2010). The ' 228 patent was classified in U.S. class/subclass $358 / 534$ for Halftone processing, "Subject matter wherein shades of various darkness 
This seems like the correct result from a Veblenian perspective, because even though arguably directed to software per se or pure information manipulation, the claimed invention was directed to a technical achievement regarding a way to render digital images that relates to providing better substantive technical performance. ${ }^{329}$ Reference to blue noise masks in the claims conveys the essential feature of the solution to the underlying technical problem addressed by the invention.

Furthermore, claims to a method for updating a web page would be patentable from a Veblenian perspective if directed to the technical mechanisms involved in web page coding and the like. For example, U.S. Patent No. 7,640,512 (filed Dec. 22, 2000) (the '512 Patent) recites:

1. A method for updating objects contained within a web page, comprising:

displaying a web page;

creating a frame having a height of zero and a width of zero within the web page;

displaying outside the frame at least one updateable object within the web page, wherein the at least one updateable object corresponds to an HVAC system;

configuring the frame to periodically request updated data from a server, the updated data comprising an instruction set for causing the frame to update the at least one updateable object;

between the darkest and lightest elements of the original object are represented by a pattern of dots of varying density in the image." U.S. Patent No. 5,341,228 col. 17 1. 55-68, (filed Dec. 3, 1991).

329 The Research Corp. decision seems like one of the most fertile grounds for finding possible agreement between the different factions on the Federal Circuit advancing competing theories for patent eligibility. 
configuring the frame to request the undated data from the server in response to a timer maintained on a client reaching a threshold value, wherein the timer is configured to be initiated as a function of creation of the frame; and

configuring the frame, in response to receiving the updated data, to cause the at least one updateable object to be updated, such that the updating of the at least one updateable object updates only a portion of the web page. $^{330}$

The invention recited in claim 1 of the ' 512 patent provides labor and/or energy saving benefits through certain uses of computers, and the claim includes steps involving specific elements of a web page (such as a frame) that provide a solution to the underlying technical problem addressed by the invention. Therefore, it seems patent-eligible in the context of the present theory.

In contrast, Ultramercial, Inc. v. Hulu, LLC involved claim 1 of U.S. Patent No. 7,346,545 (filed May 29, 2001) ("the '545 patent"), ${ }^{331}$ which recites:

1. A method for distribution of products over the Internet via a facilitator, said method comprising the steps of:

a first step of receiving, from a content provider, media products that are covered by intellectual-property rights protection and are available for purchase, wherein each said

330 In the interest of full disclosure, the author participated in the prosecution of the ' 512 patent briefly.

${ }^{331}$ Ultramercial, Inc. v. Hulu, LLC, 722 F.3d 1335, 1337-38 (Fed. Cir. 2013). 
media product being comprised of at least one of text data, music data, and video data;

a second step of selecting a sponsor message to be associated with the media product, said sponsor message being selected from a plurality of sponsor messages, said second step including accessing an activity log to verify that the total number of times which the sponsor message has been previously presented is less than the number of transaction cycles contracted by the sponsor of the sponsor message;

a third step of providing the media product for sale at an Internet website;

a fourth step of restricting general public access to said media product;

a fifth step of offering to a consumer access to the media product without charge to the consumer on the precondition that the consumer views the sponsor message;

a sixth step of receiving from the consumer a request to view the sponsor message, wherein the consumer submits said request in response to being offered access to the media product;

a seventh step of, in response to receiving the request from the consumer, facilitating the display of a sponsor message to the consumer;

an eighth step of, if the sponsor message is not an interactive message, allowing said consumer access to said media product after said step of facilitating the display of said sponsor message;

a ninth step of, if the sponsor message is an interactive message, presenting at least one 
query to the consumer and allowing said consumer access to said media product after receiving a response to said at least one query;

a tenth step of recording the transaction event to the activity log, said tenth step including updating the total number of times the sponsor message has been presented; and

an eleventh step of receiving payment from the sponsor of the sponsor message displayed.

A method that forces a consumer to view an advertisement before being granted access to a video relates to advertising revenue streams and, secondarily, to contractual or legal rights to access video content ("intellectual-property rights protection"), and is a social function that allocates economic surpluses tied to the advertisement and/or video but creates no additional surplus. ${ }^{332}$ In regard to competitive advertising, Veblen said that "[i]t gives vendibility, which is useful to the seller, but has no utility to the last buyer." 333 Moreover, if copyright laws suddenly changed, such that no copyright owner could claim exclusive rights to copying or public display, then the "invention" of the Ultramercial patent immediately loses all significance. In this way, the advertising and video access functions are social/cultural in nature (i.e., they are not transcultural) and do not appear to relate to advancement of the useful arts. From the Veblenian perspective, the claims of the '545 patent should be deemed nonpatentable, contrary to the Federal Circuit panel's holding. It is also rather glaringly apparent that claim 1 the '545 patent does not explicitly recite any solution to an

332 "The great end of consistent advertising is to establish such differential monopolies resting on popular conviction." VEBLEN, supra note 20, at 55. "Competitive advertising is an unavoidable item in the aggregate costs of industry. It does not add serviceability of the output, except be it incidentally and unintentionally." Id. at 59.

$$
333 \text { Id. }
$$


underlying technical problem. ${ }^{334}$ Rather, the recited steps discuss only routine activities phrased in such a way as to relate specifically to control of the economic market for Internet advertising and media delivery, without making a meaningful contribution to the technical knowledge within that economic market. The claim instead is at most directed toward a social problem rather than a technical problem. In short, the ' 545 patent looks like naked rent-seeking of an invidious and pecuniary nature.

In Association for Molecular Pathology v. Myriad Genetics, Inc., the Supreme Court held that isolated segments of naturally occurring deoxyribonucleic acid (DNA) are unpatentable products of nature, while synthetically created complementary DNA (cDNA) is patent-eligible. ${ }^{335}$ From a Veblenian perspective, this appears to be the right result. Identifying naturally occurring substances, or portions of them, does not create any economic surplus. A patent claim directed to such naturally occurring substances has only a pecuniary character, by directing the allocation of monetary benefits arising out of that naturally occurring substance. Limiting the patent claim to merely a segment of the overall natural substance is akin to accepting a smaller patent monopoly, but still without a contribution of workmanship. ${ }^{336}$ Yet, in contrast, synthesizing new compounds that are not naturally occurring may involve workmanship, regardless of any moral objections that might be raised when the

334 Ultramercial, 722 F.3d at 1355 (Lourie, J., concurring) ("While a computer or complex computer program, as discussed by the majority opinion, may be necessary to perform the method, it is not what the claim specifically requires.").

${ }^{335}$ Ass'n for Molecular Pathology v. Myriad Genetics, Inc., 133 S. Ct. 2107, 2111 (2013).

336 Following the author's "Spanish method" analogy, any defense of patentability premised on the effort needed to isolate desired segments of naturally occurring materials should be no more convincing than an argument that the expense for a conquistador to sail across an ocean and plant a flag on existing territory renders such conduct "inventive." 
synthesis involves biologic matter. Thus, the Supreme Court seemed to track the Veblenian perspective in their distinction between the patent eligibility of synthetic cDNA and isolation of segments of naturally occurring DNA.

No doubt, limitless examples could be given. In many of these examples, a real technical accomplishment may be present and could theoretically be claimed, but often patent applicants choose to focus instead on only pecuniary aspects, most assuredly to seek preemptive monopoly coverage.

\section{THE IMPORT OF THE NEW THEORY OF PATENT ELIGIBILITY}

\section{A. The Veblenian Viewpoint and "Progress" of the "Useful Arts"}

What is lacking in much writing on patent subject matter eligibility is open discussion of the desired ends of the inquiry. Instead, an excessive focus on the process of patentability leads to voluminous tracts on the tedious workings of one test versus another for identifying patent-eligible subject matter, all the while leaving unstated the social impacts and ideological bases-a problem very much like that found with the insistence on decontextualized marginal analysis in neoclassical economics. But a Veblenian perspective can shift the focus of this debate by providing a more richly nuanced critique of how self-interest correlates to the various incentive theories for patents, such as those expressed in the Patent \& Copyright Clause of the Constitution. ${ }^{337}$ This is because Veblen was, at bottom, a

${ }^{337}$ Leo Marx has written about how Veblen's use of the term "technology" might link to the efforts of Thomas Jefferson, Benjamin Franklin, Thomas Paine, and others to frame the modern concept of "progress." Leo Marx, Technology: The Emergence of a Hazardous Concept, 51 TECH. \& CULTURE 561, 564-65 (2010). All found technology in the form of "advances in science and the mechanic arts valuable chiefly as means for arriving at social and political ends." Id. at 565. Although Marx does not develop this point, Veblen's usage included some recognition of the views of environmentally conscious thinkers like John Muir, Henry David Thoreau and others who criticized industrialization. E.g., Russell H. Bartley \& Sylvia E. Yoneda, Thorstein Veblen 
moralist - constructing theories that relied upon only very basic and elemental normative judgments, such as favoring equality over inequality $^{338}$ - and his career focused primarily upon criticisms of myopic economic methodologies that bracketed out all cultural questions in order to make certain pre-determined or inherent moral judgments undiscussable.

Institutionalist economists offered explanations for distinctions between different economic activities that are useful in the context of patentable subject matter inquiries. Veblen distinguished business enterprise and technology in modern society with his dichotomy. Yet his evolutionary view looks at outcomes as if in a constant state of flux, with disparate forces interacting. "Culture advances and evolves via the cumulative and dynamic forces of industry and technology juxtaposed to the static forces of the ceremonial and the pecuniary." 339 Whether this results in "progress" is uncertain, though. From a Veblenian perspective, "financially oriented business behavior makes the social provisioning process more unstable and renders people's welfare more vulnerable." "340 Veblen believed that "[a] civilization which is dominated by th[e] matter-of-fact insight [of technology and the

on Washington Island: Traces of a Life, 7 INT'L J. POL., CulTuRE \& SOC'Y 589, 602 (1994), available http://www.islandheritageconservancy.com/other/Thorstein $\% 20$ Veblen $\% 20$ on\% 20Washington\%20Island.pdf. A fair reading of Veblen here would include recognition that he tried to separate out the respective roles of technology and the pecuniary, indicating that the two influenced each other, which could lead to positive or negative outcomes.

338 O'Hara, supra note 14 at 83.

339 Richard L. Brinkman, Culture in Neoinstitutional Economics: An Integration of Myrdal and Galbraith into the Veblen-Ayres Matrix, 40 AM. J. ECON. \& SoC. 401, 402 (1981).

340 JO \& HENRY, supra note 52, at 2. 
machine process] must prevail against any cultural scheme that lacks this element." ${ }^{341}$ History lends support to the theory. ${ }^{342}$

Ever since the mercantilist era, using technology to maximize productivity had long been a basic strategy of national power. This was the context in which Veblen warned that the problem of high finance was its tendency to deviate from technological efficiency, to form a symbiosis with speculative activities and defend the vested interests (the term he coined for rentier real estate, finance and monopolies). ${ }^{343}$

As detailed by Alan Durham, then Treasury Secretary Alexander Hamilton wrote on how patents encourage industry and manufactures in 1790, in much the same way Veblen later wrote about fostering workmanship and machine knowledge to help create economic surplus. ${ }^{344}$ But where Veblen goes a step beyond

${ }^{341}$ Thorstein Veblen, The Place of Science in Modern Civilisation, 11 AM. J. Soc. (1906) reprinted in THE Place OF SCIENCE IN MODERN Civilisation AND OTHER ESSAYS 2 (B.W. Huebsch 1919).

342 William T. Ganley, The Theory of Business Enterprise and Veblen's Neglected Theory of Corporation Finance, 38 J. ECON. IsSUES 397, 400-01 (2004).

343 Michael Hudson, The Social Economics of Thorstein Veblen, EH.NET (Oct. 2012), http://eh.net/book_reviews/the-social-economics-of-thorsteinveblen; see also MicHAEL HUDSON, AMERICA'S PROTECTIONIST TAKEOFF 18151914: The Neglected AMERICAN SCHOOL OF PolitiCAL ECONOMY (2010). For an exposition on Veblen's engineering-focused rather than economic-focused discussions of "efficiency," see Janet T. Knoedler, Veblen and Technical Efficiency, $31 \mathrm{~J}$. ECON. ISSUES 1011 (1997).

344 Alan L. Durham, "Useful Arts" in the Information Age, 1999 BYU L. REv. 1419, 1454 (1999). Alexander Hamilton established the Bank of New York, and was a prominent banker in the American Revolutionary era. His more restrictive views on what types of subject matter are patent-eligible can be contrasted with those of some financial interests today. If a banker like Hamilton did not see patents encompassing business methods and financial 
the established view (that technology and industry can advance general well-being of a population) was in his recognition of certain ways that technological gains can be thwarted.

Veblen issued a warning of a parasitic role of finance in relation to engineers and real industry. ${ }^{345}$

Written in a popular sarcastic style, [Veblen's] books showed how the behavior of wealth and high finance was having perverse effects after World War I. Instead of funding economic growth, Wall Street was becoming the protector of privilege and engaging in artful deception, distorting economies away from passing on the fruits of technology to populations in the form of rising living standards and falling costs of living and doing business. ${ }^{346}$

Veblen's critical view of the evolution of capitalism into finance capitalism is the polar opposite of that of Joseph Schumpeter, who, despite sharing some theoretical ground with Veblen, viewed big-business capitalism as a model of efficiency. ${ }^{347}$ "Whereas Schumpeter envisions [business enterprise and technology] as integrally connected and perfectly harmonious, Veblen sees them coming increasingly into conflict." 348 To Veblen,

activities when the Constitution was framed, then contrary views start to seem out-of-step with original intent.

345 ThORSTEIN Veblen, THE ENGINEERS AND THE PRICE SYSTEM (1921); $c f$. Gabriel KolKo, THE TriUmPH OF CONSERVATISM: A REINTERPRETATION OF AMERICAN HISTORY, 1900-1916 (1963); FISK, supra note 37, at 9-11, 75-172.

${ }^{346}$ Hudson, supra note 343.

347 L.A. O’Donnell, supra note 305, at 222-23. Rudolph Hilferding, who coined the term "finance capitalism," advanced views akin to Veblen's. See generally RUDOLPH HILFERDING, DAS FINANZKAPITAL [FINANCE CAPITAL] (1910). Schumpeter shared many theoretical commonalities with Veblen, but the two diverged on many conclusions.

348 L.A. O'Donnell, supra note 305, at 199; see also Jo \& HENRY, supra note 52 , at 5 . 
equality was a central concept, and he viewed business-as distinguished from industry - as the source of inequality. ${ }^{349}$ "Veblen and his fellow institutionalists understood that 'the market' was distorted by special 'free lunch' privileges to extract income without really contributing to production." 350

The word which best characterizes Veblen's view of business methods is 'sabotage.' By it he means 'a conscientious withdrawal of efficiency.' To him it is so obvious as to be self-evident that prices cannot be maintained at a reasonable profitable level without the 'habitual recourse to delay and obstruction of industry.' This theme recurs endlessly in Veblen's work. ${ }^{351}$

Veblen's views formed much of the basis for the analyses of sociologist Alain Touraine, who was an early commentator on the concept of the "post-industrial society" that is so often used in the context of the contemporary patentable subject matter debate. ${ }^{352}$

349 TILMAN, supra note 215, at 105. Contra, e.g., Cotter, supra note 11, at 855 . There are a number of books by journalists that approach this topic —or at least the effects - of corporate financialization from an emotional perspective, relying heavily on anecdotes and case studies. E.g., JILL ANDRESKY FRASER, WHITE-COLLAR SWEATSHOP: THE DETERIORATION OF WORK AND ITS REWARDS IN CORPORATE AMERICA (2001).

${ }^{350}$ Hudson, supra note 343.

351 O'Donnell, supra note 305, at 210; see also Wray, supra note 13, at 619. For a contemporary version of this sort of "sabotage" by financiers and bankers, see, e.g., Ellen Brown, Larry Summers and the System: Making the World Safe for Banksters, COUNTERPUNCH (Sept. 5, 2013), http:// www.counterpunch.org/2013/09/05/making-the-world-safe-for-banksters. There is also something of a merger underway between the use of the World Trade Organization to globally impose the North Atlantic States' version of patent laws and attempts to unleash the North Atlantic States' financial products on the globe. See PRASHAD, supra note 79.

352 Alain TOURaine, The POST Industrial SOCIETY: TOMORROW'S Social History: Classes, Conflicts, and Culture in the PRogrammed SOCIETY 140, 148-49, 152, 166-67 (Leonard F. X. Mayhew trans., Random House, 1971) (1969). Touraine built on a Veblenian framework, stating that 
An example of business sabotage of industry is planned obsolescence, including everything from constant stylistic redesigns to drive conspicuous consumption, products that force needless wear part replacements, products that are incapable of repair, unsupported computer software dubbed "adandonware," and more. ${ }^{353}$ The artificial electrical power brownouts/blackouts devised by Enron to inflate associated prices certainly provide a prime example. ${ }^{354}$ Another example from popular cinema that might illustrate this point from a different perspective is Happy Gilmore, in which the titular character (played by Adam Sandler) is a failed hockey player who revolutionizes professional golfing, with the antagonist, Shooter McGavin (played by Christopher McDonald), representing the "vested interests" continually trying, but failing, to sabotage Happy Gilmore's performance in order to try to maintain his own public standing. ${ }^{355}$

Veblen's insights have clear parallels in determining under the Constitution what constitutes "promot[ing] the Progress of Science and useful Arts." 356 What is "progress" in the context of the Patent $\&$ Copyright Clause of the Constitution if not passing along the

when "economic growth comes to depend more on the capacity to mobilize and organize resources, to direct change, and to foresee and program development . . .. [T] he efficiency of the firm depends more and more on social and political determinants and on the general functioning of the economic system." Id. at 157. Touraine nonetheless makes numerous criticisms of Veblen's theories, often without specifically identifying Veblen by name.

353 See generally GILES SLADE, MADE TO BREAK: TECHNOLOGY AND OBSOlESCENCE IN AMERICA (2006); VANCE PACKARD, THE WASTE MAKERS (1960).

354 Tapes: Enron Plotted to Shut Down Power Plant, CNN.COM (Feb. 3, 2005, 11:28 PM), http://www.cnn.com/2005/US/02/03/enron.tapes/; Timothy Egan, Tapes Show Enron Arranged Plant Shutdown, N.Y. TiMES (Feb. 4, 2005), http://www.nytimes.com/2005/02/04/national/04energy.html.

355 HAPPY GILMORE (Universal Pictures 1996).

356 U.S. CONST. art. I, § 8, cl. 8; see also Irwin, supra note 9, at 785 (identifying egalitarian social progress in the Enlightenment vision of technology adopted by Founding Fathers). 
benefits of technology to the general population in terms of rising standards of living? $?^{357}$ Veblen's ideas on the industrial/pecuniary dichotomy found precedent in European Enlightenment era concepts that tolerated private greed only when they coincided with public good. ${ }^{358}$ Given that the Framers of the Constitution were steeped in Enlightenment-era thought, ${ }^{359}$ this is a salient point on understanding a possible interpretation of the limits on promoting progress of the useful arts. Dana Remus (née Irwin) has written on the need to re-craft patent eligibility standards such that they reclaim their normative roots and consider social benefit again. ${ }^{360}$ Justice Stevens reached a similar conclusion in his concurrence to the Bilski decision. ${ }^{361}$ Such views can be developed further with reference to Veblen's theories.

Institutionalist economics recognizes that the FIRE sector and business interests generally will almost always view their own

357 But see Malla Pollack, What is Congress Supposed to Promote?: Defining "Progress" in Article I, Section 8, Clause 8 of the United States Constitution, or Introducing the Progress Clause, 80 NEB. L. REv. 754, 755-77 (2001). Pollack discusses a theory for the "1780s meanings of "progress," primarily in relation to the copyright portion of the Patent \& Copyright Clause of the Constitution. Id. However, that analysis is limited to the word "progress" largely decoupled from "useful arts," and therefore it omits nuance regarding how the "useful arts" differ from "science." Moreover, it presumes that the Constitution is more inflexible than it need be. Nonetheless, interpreting "progress" to mean "spread" as Pollack does, only a small step is required to translate "spread" to industrialization and the increase in technological efficiency and dissemination of "matter-of-fact" knowledge in the sense of Veblen's usage.

${ }^{358}$ Reinert, supra note 18, at 61; see also, e.g., VEBLEN, supra note 20, at $38-44$.

${ }^{359}$ Irwin, supra note 9, at 785-89 (identifying an Enlightenment vision of technology adopted by Founding Fathers when the Constitution was framed).

${ }^{360}$ Id. at $815-23$.

${ }^{361}$ See generally Bilski v. Kappos, 130 S. Ct. 3218, 3232 (2010) (Stevens, J., concurring) (arguing that "restor[ing] patent law to its historical and constitutional moorings" by limiting the patentability of business processes will promote socially beneficial innovation as the Founders intended). 
activities favorably, but also that such views must be assessed in relation to the greater social good. For example, in The Fisherman and the Rhinoceros: How International Finance Shapes Everyday Life, Eric Briys and François de Varenne lamented the "tyranny of the real economy" and trumpeted the success of Enron-prior to the exposure of Enron's fraudulent accounting practices. ${ }^{362}$ Their view, as proponents of financial interests, is that "the speculator is not a parasite on the real economy, but almost a saint, someone who helps everyone by taking on the specialized task of managing risks. For assuming these risks, the speculator gets the chance of profits." 363 Such a FIRE sector perspective is an about-face from that of institutionalist economists. To Veblen, the term "social" means collective equality. ${ }^{364}$ The award of a patent to an individual (or small groups of individuals or entities) on the basis of a social, that is, collective, phenomenon, is a harmful inequality that lessens social welfare and reduces economic growth. From such a point of view, patent claims - particularly method claims - to invidious business endeavors that are fundamentally social can never be useful or promote progress of science and the useful arts, because they are always stultifying or regressive with respect to collective

362 ERIC BRIYS \& FRANÇOIS DE VARENNE, THE FisheRMAN AND THE RHINOCEROS: HOW INTERNATIONAL FINANCE SHAPES EVERYDAY LIFE (2000); see also JAMES N. BODURTHA, JR., "UNFAIR VALUES" - ENRON'S SHELl GAME (2003), http://bodurtha.georgetown.edu/enron/bodurtha_enron_shell_game.pdf (discussing Enron's fraudulent practices). The financial industry often trumpets itself, even within the realm of patent law. See, e.g., John A. Squires \& Thomas S. Biemer, Patent Law 101: Does a Grudging Lundgren Panel Decision Mean that the USPTO is Finally Getting the Statutory Subject Matter Question Right?", 46 IDEA 561, 563-67 (2006) (Mr. Squires wrote as the Chief Intellectual Property Counsel for Goldman, Sachs \& Co., a leading securities and investment banking firm).

363 Justin Podur, Monstrous Gambles on the Future: The Financial Economy and Real Economy, COUNTERPUNCH (Oct. 15, 2008), http:// www.counterpunch.org/2008/10/15/the-financial-economy-and-real-economy.

364 TILMAN, supra note 215, at 106. 
equality and therefore antagonistic to "progress" and

As capitalism took the fore, and the U.S. economy industrialized from the Nineteenth Century to the early Twentieth Century, the role of "creators" faded from view, and "the relationship between the marketers and the consumers became dominant." 366 If the transition to a "post-industrial" economy is given credence, it is possible to question the continued relevance of patent law to such a post-industrial economy. In the realm of patentable subject matter, the question is whether "creators" of inventive technology, as traditionally understood, risk disappearance altogether, increasingly replaced by the direct patenting of the relationships between marketers (or rentiers) and consumers - and whether such a shift provides any public good. The Veblen dichotomy bears on how such a shift impacts society as a whole. He provided a theoretical link between collective wellbeing, equality, and a preference for workmanlike application of matter-of-fact technical knowledge over the pecuniary, unproductive application of business and financial control. Contemporary empirical research supports Veblen's theory, indicating that increasing financialization of the U.S. economy has "negative effects on equality, growth and employment.",367 Although some critics fault Veblen for failing to articulate a sufficiently clear standard for his dichotomy, perhaps because they preferred different normative conclusions, Veblen nonetheless provided a theoretical link between notions of progress and growth and the application a dichotomy of some sort. In the patent world, this provides a basis for discussion of constitutional limits on the patent statutes with regard to patent-eligible subject matter, particularly with regard to "business methods" and other abstract

365 See generally JARON LANIER, WHO OWNS THE FUTURE? (2013) (providing a similar, if less philosophically clear, argument with respect to information and "big data" and other contemporary technology).

366 FiSK, supra note 37, at 11.

367 Jacob Assa, supra note 46, at 38. 
ideas. The most striking possibility here is the notion, derived from Veblen's economics, that business method and other abstract patents could actually further a relative regression in general wellbeing by adding patents to the usual complement of techniques of pecuniary sabotage and exacerbating imbalances between the FIRE sector and the rest of the economy.

Here the remarkable book by Peter Drahos with John Braithwaite, Information Feudalism: Who Owns the Knowledge Economy? deserves special attention. ${ }^{368}$ Although Veblen is never mentioned, Drahos and Braithwaite reach essentially the same conclusion that Veblen did in books like Absentee Ownership and Business Enterprise in Recent Times: The Case of America, ${ }^{369}$ that FIRE sector interests can overtake and disrupt the real economy to the detriment of general public welfare, and they tie that conclusion to contemporary international negotiations over intellectual property rights treaties and the rise renewed influence of feudal-like conditions.

The present approach to patent eligibility is far more sweeping than more limited technical criticisms regarding financial and business method patenting, which often focus on the procedural and technical competency of the USPTO to examine such patent applications in the same manner as applications in other subject matter areas, or judicial review of such patents after issuance. ${ }^{370}$

368 DRAHOS WITH BRAITHWAITE, supra note 54; see also Drahos, supra note 54, at 209-222.

369 VEBLEN, supra note 78.

370 See, e.g., Michael Moulton, Effecting the Impossible: An Argument Against Tax Strategy Patents, 81 S. CAL. L. REV. 631 (2008). There is no shortage of possible procedural and administrative or judicial competency arguments against expanding patent-eligible subject matter. For instance, social science backgrounds are not accepted to satisfy eligibility requirements for the patent bar. U.S. PATENT AND TRADEMARK OFFICE, GENERAL REQUIREMENTS BULLETIN FOR ADMISSION TO THE EXAMINATION FOR REGISTRATION TO Practice in Patent Cases Before the United States Patent AND TRADEMARK OFFICE 4 (2014), available at http://www.uspto.gov/ip/boards/oed/ 
Yet Veblen's analysis of the economic role of technology is premised on many of the same Enlightenment era ideals that originally gave rise to the Patent \& Copyright Clause in the Constitution. Amid a confusing array of theories for patent eligibility, Veblen at a minimum suggests that the motives behind some are to recreate the near-feudal economic conditions of the pre-Enlightenment era, ${ }^{371}$ with a corresponding diminishment in public well-being. It becomes a question of underlying ideologies.

\section{A. Why Perspective Matters}

The policy implications of the patentable subject matter debate can be informed by a recognition that ideology is a driving force behind what are often presented as "objective" arguments. ${ }^{372}$ One

exam/GRB_January_2014.pdf. A bachelor's degree in a recognized technical subject, or evidence of another degree with equivalent scientific and technical training, are accepted, as is evidence of practical engineering or scientific experience. $I d$. In other words, attorneys and agents practicing before the USPTO in patent matters cannot qualify based on experience with marketing, social sciences, finance, politics, or the like. The tired joke, "I have a science background: in political science," comes up short. Although the matter of practitioner credentialing is very nearly an afterthought when considering the substantive question of patent subject matter eligibility, it does further emphasize how finance, business, and other social sciences have traditionally not been considered disciplines that deal with patentable subject matter. This underscores how much recent patent activity has shifted into new areas without significant historical precedent. But it is also an attack on institutional practices, and a very procedural one at that. Without a broader theoretical basis - and therefore reminiscent of the sorts of analyses Veblen derided as mere "taxonomy" in economics - these sorts of analyses will never provide any definitive resolutions.

371 Cf. DRAHOS WITH BRAITHWAITE, supra note 54.

372 Judge Richard Posner has made this point before in reference to arguments from Justice Antonin Scalia and Bryan Garner regarding the alleged objectivity of the "textualist" statutory interpretation methodology. Richard A. Posner, The Incoherence of Antonin Scalia, NEW REPUBLIC (Aug. 24, 2012), http://www.newrepublic.com/article/magazine/books-and-arts/106441/scaliagarner-reading-the-law-textual-originalism (book review of ANTONIN SCALIA \& 
useful insight, advanced by philosopher Slavoj Žižek and others, ${ }^{373}$ is that "[t]he fundamental aim of ideological fantasy is to silence social antagonism," and "[t]he only way of not falling into ideological thought is, then, to maintain the tension between ideology and reality, although they cannot be clearly separated from one another." ${ }^{374}$ In this sense,

it is not simply a matter of seeing which account of reality best matches the 'facts', with the one that is closest being the least biased and therefore the best. As soon as the facts are determined, we have already - whether we know it or not - made our choice; we are already within one ideological system or another. ${ }^{375}$

Yet the nature of ideology is to keep its aims of rationalization hidden. ${ }^{376}$ As jurists and commentators weigh the various

Bryan A. GARner, REAding LAW: ThE InTERPREtation of LEgAL TEXTS (2012)).

373 A "post-modern" view of patent-eligible subject matter has been suggested. Irwin, supra note 9, at 815-16. Post-modernism is a precursor to the views advanced by Žižek. The emphasis on dynamic, context-dependent tensions in Žižek's philosophy has many similarities with old institutional economics. See HÄRING \& DOUGLAS, supra note 56, at 8-11.

374 George I. García \& Carlos Gmo., Psychoanalysis and Politics: The Theory of Ideology in Slavoj Žžek, 2 INT. J. ZIZEK STUD. 8-9 (Imanol Galfarsoro trans., 2008), available at http://zizekstudies.org/index.php/ijzs/ article/viewFile/149/243.

375 Rex Butler, Zizek: What is a Master-Signifier, LACAN.COM, http:// www.lacan.com/zizek-signifier.htm (last visited Mar. 25, 2014). This is analogous to an Albert Einstein quote: "Whether you can observe a thing or not depends on the theory which you use. It is the theory which decides what can be observed." See ABDus SALAM, UnifiCATION OF FundamENTAL FORCES 99 (Cambridge Univ. Press 1990).

376 García \& Gmo, supra note 374, at 3 ("[I]deology always implies a concealment: 'to be effective, the logic of the legitimation of the relations of domination must remain hidden."'); SLAVOJ ŽIŽEK, THE FRAGILE ABSOLUTE: OR, Why IS THE Christian Legacy Worth Fighting For? 16 (Verso 2000) 
proposals for patent subject matter eligibility, they do so against a typically unstated ideological backdrop, which too often makes the associated statements of "facts"-as pertaining to "purely mental steps," a "transformation of matter," a connection to a "machine," or any other patentability litmus test-more of an expression of the unstated ideology than the reliable and objective judgments they are made out to be. Much of the confusion in Federal Circuit case law centers on this problem.

With that said, the present theory on patent eligibility exhibits a stark departure from certain views on patent law gradualism-the notion that the scope of patent-eligible subject matter should slowly continue to increase. The Veblenian perspective suggests that patent law should not be shaped and adjusted to defend and accommodate vested social privileges, but should instead be more egalitarian and should be reevaluated over time in view of constantly changing circumstances. ${ }^{377}$ In contrast, Thomas Cotter wrote about evaluating patent subject matter eligibility from a "Burkean perspective," and recognized, if only by implication, that evaluation of any test or tests for patent subject matter eligibility must be made against some sort of ideological backdrop. ${ }^{378}$ Cotter

(" $[\mathrm{T}]$ he highest form of ideology lies not in getting caught in ideological spectrality, forgetting about its foundations in real people and their relations, but precisely in overlooking this Real of spectrality, and pretending to address directly 'real people with their real worries'. Visitors to the London Stock Exchange are given a free leaflet which explains to them that the stock market is not about some mysterious fluctuations, but about real people and their products - this is ideology at its purest."); see also Posner, supra note 367.

377 Contra Cotter, supra note 11, at 857 ("[T] he extent to which [Burkean] tradition reflects the perspectives of elites clearly presents a bone of contention for thinkers more inclined towards egalitarianism.").

${ }^{378}$ Id.; Thomas F. Cotter, A Burkean Perspective on Patent Eligibility, Part II: Reflections on the (Counter) Revolution in Patent Law, 11 MINN. J.L. SCI. \& TECH. 365, 365-66 ("I contended that it would be inadvisable to exclude computer and business-related art from the scope of patentable subject matter altogether."). Cotter's "Burkean" view starts down the same direction as the Veblenian one, suggesting that limits on patent eligibility are appropriate, but in true Burkean fashion obfuscates the social context as to why that would matter. 
endorses Irish statesman Edmund Burke as a reference point, whereas the present article rejects Burke and proffers Veblen (and institutional economics more generally) as a superior alternative. Burke's philosophical outlook was, at bottom, an attempt to restrain emancipatory and disruptive social movements, ${ }^{379}$ and that included restraining entrepreneurial inventors whose inventions chipped away at the supremacy of an existing aristocracy, whereas Veblen noted the unique role of technology and industry in disrupting vested interests for the possible advancement of the "generic ends of life." 380 Veblen saw the possibility for social good

379 During his lifetime, Burke was "a leader of the anti-patent campaign" in England. Kent, supra note 275, at 221 (citing PAUL MANTOUX, THE INDUSTRIAL REVOLUTION 336 (London 1928)).

${ }^{380}$ For a general critique of Burke and his progeny, see COREY ROBIN, THE REACTIONARY Mind: CONSERVATISM FROM EDMUnd BuRKe to SARAH PALIN (Oxford Univ. Press 2011) (placing Burke on a continuum of reactionary thinkers seeking to protect established hierarchy against emancipatory movements from below). Against Robin's analysis of Burke, it is interesting that Chief Judge Rader of the Federal Circuit wrote an op-ed in 2013 that seems to tie in closely with the fact that he offered comments to Cotter on the Burkean view of patent eligibility. Randall R. Rader et al., Make Patent Trolls Pay in Court, N.Y. TIMES, June 5, 2013, at A25, available at http://www.nytimes.com/ 2013/06/05/opinion/make-patent-trolls-pay-in-court.html; see also Charles Arthud, Obama Takes Aim at 'Patent Trolls', THE GUARDIAN, June 5, 2013, available at http://www.theguardian.com/technology/2013/jun/05/obama-patenttrolls (quoting J. Randall R. Rader); Randall R. Rader, Chief Judge, United States Court of Appeals for the Fed. Cir., The State of Patent Litigation, Address at the E. Dist. Tex. Judicial Conference (Sept. 27, 2011) (transcript available at http://memberconnections.com/olc/filelib/LVFC/cpages/9008/Library/

The $\% 20$ State $\% 20$ of $\% 20$ Patent $\% 20$ Litigation $\% 20$ w\%20Ediscovery $\% 20$ Model $\%$ 20Order.pdf). A crucial point here is that Judge Rader's suggestion to value patent litigation early implies that technical (i.e., useful) aspects of a patented invention drive valuation. One of Veblen's more remarkable contributions to this most daunting question of economics-how to assess value?-was his recognition that pecuniary interests can influence or outright impose valuations on serviceable technology, suggesting that valuation occurs in the opposite manner to what Rader implies. See Wray, supra note 13, at 618; Hobson, supra note 30. In the patent context, the Veblenian view is that the legal mechanisms at play in patent litigation drive valuation independent of usefulness at large of 
in such disruption. Here, it should be noted that "[e]ver since antiquity, the useful arts in their various guises had been considered intellectually and socially inferior to the high (or fine, or creative, or imaginative) arts." 381 It is precisely in this context that Veblen, somewhat like Thomas Jefferson et al., ${ }^{382}$ saw technology as a means of sociopolitical change working against vested interests, making the Veblenian view of technology potentially more consistent with the revolutionary era conception of promoting progress in the useful arts than a Burkean view that must generally be seen as seeking to protect vested interests from disruption. ${ }^{383}$

Moreover, Veblen saw the pecuniary activities of business and finance as bearing the large share of responsibility for fluctuations in and de-synchronization of an economy on a macro scale,

the claimed invention. Moreover, even though the argument by Rader et al. emphasizes the toll allegedly imposed on small companies, there is nothing in current patent laws that exempts small companies from patent infringement. Rightly or wrongly, the patent laws treat all parties the same regardless of size, ability to monitor the patent landscape, or resources to defend against frivolous litigation. Moreover, start-up companies are sometimes merely the playthings of venture capitalists and therefore still as much "vested interests" in the Veblenian sense as large companies. The notion that patents impose a sort of "tax" on productive business is in line with many of Veblen's original criticisms of pecuniary activities (in which legal work was included) wastefully raising the general cost of doing business. It is an argument that when taken to its logical conclusion is one against the very existence of patents (and other intellectual property). At bottom, too, it is merely a generalized complaint against frivolous litigation, which is not unique to patent law by any means-with no clear mechanism in sight to quickly, reliably and fairly separate the frivolous from the nonfrivolous.

${ }^{381}$ Marx, supra note 274, at 573.

${ }^{382}$ See Irwin, supra note 9, at 789; Marx, supra note 274, at 565.

${ }^{383}$ Although neither Burke nor Veblen favored patents, their rationales for arriving at their respective positions were polar opposites. 
particularly in relation to economic crises that harm general welfare. $^{384}$

Veblen specifically focuses on the problem how domination and direction of industrial activities by financial activities result in instabilities and fluctuations in economy. At this point, Veblen asserts that fluctuations in [the] economy do not stem from [the] industrial sector, but from activities that business enterprises follow for more profit. Veblen defines fluctuations emerging at the level of financial activity not as industrial fluctuations but as business cycles. In this sense, Veblen indicates crisis and financial fluctuations in modern economy not as a result of [the] industrial economy but as a result of [the] money economy. ${ }^{385}$

The self-interested views of the FIRE sector can be seen in a stark new light from this perspective. For instance, commentator John Duffy took quite literally the notion that "financial engineering" is indeed a new form of engineering, noting that Princeton University had created a Department of Operations

384 VEBLEN, supra note 20, at 14-32; see also Gülenay Baş Dinar, Conflict between Industrial and Financial Activities and Instability of Capitalism in Veblen's Analysis presented at the Veblen, Capitalism and Possibilities for a Rational Economic Order Symposium, available at http:// www.veblenconference.org/en/ index.php?option=com_content $\&$ view=article $\&$ id=73:guelenay-badinar\&catid=47:paper-owners\&Itemid=101 (last updated June 18, 2012); Little, supra note 20.

385 Gülenay Baş Dinar, Abstract: Conflict Between Industrial and Financial Activities and Instability of Capitalism in Veblen's Analysis presented at the Veblen, Capitalism and Possibilities for a Rational Economic Order Symposium, available at http://www.veblenconference.org/en/ index.php?option=com_content $\&$ view=article $\&$ id=73:guelenay-badinar\&catid=47:paper-owners\&Itemid=101 (last updated June 18, 2012). 
Research and Financial Engineering. ${ }^{386}$ In such a view, the scope of "technological arts" is flexible and should be expanded to include activities of the financial sector or any other sector that may dominate the economy in the future. Insiders in the FIRE sector tend to view themselves as engineers in this way too. ${ }^{387}$ From the Veblenian perspective, that view is suspect because it is rooted in status and institution instead of taking a functional approach with respect to productive contribution. ${ }^{388}$ Princeton University creating such a department within their engineering school raises the same questions posed by the formation of business schools nearly a century earlier, many of which were created not to develop new curricula, but "(a) to engage and serve the local business community, and thereby attract students and donations, and (b) to steal away the significant paying business education that was already being done by many nation-wide nonacademic schools of commerce." 389 Duffy gives academic

386 Duffy, supra note 35, at 1268-69. Duffy's views are not uncommon here. For instance, the television program NOVA ran an episode on October 16, 2013 titled "Making Stuff Faster" that blurred the lines between what might be called the useful arts and business management when discussing operations research initiatives. How to Run Faster, ScI. AM. (Oct. 16, 2013), http:// www.scientificamerican.com/article/how-to-run-faster-video.

387 Engineering, machinery and technology metaphors now abound in describing financial and business activities. See, e.g., John Cassidy, Mastering the Machine: How Ray Diallo Built the World's Richest and Strangest Hedge Fund, THE NEw YORKER, July 25, 2011, http://www.newyorker.com/reporting/ 2011/07/25/110725fa_fact_cassidy; SCOTT PATTERSON, THE QUANTS: How A NeW Breed of Math Wizzes Conquered Wall Street and Nearly DeStroyed It (2010); see also John A. Squires and Thomas S. Biemer, Patent Law 101: Does a Grudging Lundgren Panel Decision Mean That the USPTO Is Finally Getting The Statutory Subject Matter Question Right?, 46 IDEA 561 (2006). However, '[t] he strategy of 'financial engineering' is to make capital gains by downsizing and breaking up companies, or to bid up their stock prices rather than investing in more capital or hiring more employees." HUDSON, supra note 10 , at 251 .

388 Duffy's view does, however, resemble the "Burkean" view. See supra Part I.

${ }^{389}$ LOCKE \& SPENDER, supra note 74 , at 8. 
institutions a free pass, assuming that any of their activities must inherently be academic in nature due to their institutional status as "universities." 390 Yet the history of business schools shows a clear tendency towards wealth- and prestige-seeking activities among universities and colleges that is at odds with the somewhat naïve view of such schools as having purely academic motives. Veblen wrote an entire book on this topic, The Higher Learning in America: A Memorandum on the Conduct of Universities by Business Men. ${ }^{391}$ Moreover, even though there is now a professional organization-The International Association of Financial Engineers - that seeks to bolster the field of quantitative finance, ${ }^{392}$ it is difficult to see how "financial engineering" bears any relation to technology as it is commonly understood. The term "financial engineer" seems no more credible than a description of a homemaker as a "domestic engineer." 393 That is not meant to denigrate homemaking but rather emphasize that it is entirely different from engineering as the term is commonly understood. ${ }^{394}$

390 For further criticism of Duffy's views here, see BEN KLEMMONS, TECHNOLOGICAL ARTS 2 (2009) ("John Duffy proposed that we should take an 'I know it when I see it' sort of approach: if it's taught at a technical college then it's a technological art."), available at http://ben.klemens.org/blog/pdfs/ 012-bilski_v_kappos.pdf.

391 Thorstein Veblen, The Place of Science in Modern Civilisation AND OTHER ESSAYS, supra note 29, at 186.

392 INT'L ASS'N FIN. ENGINEERS, http://iafe.org (last visited Feb. 9, 2014).

393 Kate Lorenz, Six Ways to Embellish Your Resume Without Lying, EXPERIENCE, http://www.experience.com/alumnus/ article?channel_id=Resumes\&source_page=additional_articles\&article_id=artic le_1203709417499 (last visited Mar. 4, 2012) (explaining that to "[a]void halftruths and gross exaggerations," job applicants are advised that "[m]ost hiring managers and recruitment professionals have had their share of resumes pass across their desks during their career. So they are usually adept at deciphering embellishments in a resume. They know that spending the last 10 years as a 'domestic engineer' means you simply were home with your kids.").

394 Much as noted by LEWONTIN ET AL., supra note 39, this is generally an attempt to acquire credibility through association with "engineering," a 
Economists in the tradition of Veblen view "financial engineering" not as a form of engineering like mechanical, chemical or electrical engineering, but rather as synonymous with speculation and debt leveraging. ${ }^{395}$ So while today's "financial engineers" may have backgrounds in actual science and engineering, a distinction should still be drawn in the Veblenian sense regarding the unproductive functional nature of their current financial activities.

\section{CONCLUSION}

The present proposal offers a new perspective on patent subject matter eligibility, and one that is sharply divided from and considerably narrower than certain other frameworks. Veblen's key insights into the sorts of artful deception engaged in by parasitic, nonproductive economic sectors roughly a century ago is useful for identifying how the same sophistries are being employed by business interests today to distort patent law through an expansion of patent eligibility. In an era when the gravitational pull of the FIRE sector and related unproductive industries in the economic field has perhaps even exceeded that of industry, Veblen's theoretical framework offers much-needed insights as to how such a pecuniary/industrial imbalance in the economic field can influence the conception of patent-eligible subject matter in a way that has a negative impact on the advancement of general welfare. Adopting a Veblenian perspective for patent subject matter eligibility would preclude numerous swaths of "invention" currently allowed by the USPTO and acceptable under current judicial tests (e.g., the "coarse filter" approach). However, despite this retraction in the scope of patent subject matter eligibility, such an approach would merely restrain patenting within boundaries more consistent with historical practice, long-standing Supreme

discipline widely acknowledged to serve the public interest, by actors working in disciplines not widely accorded the same status.

${ }^{395}$ Hudson, supra note 223; cf. GALBRAITH, supra note 284, at 19. 
Court precedent, and constitutional limits. ${ }^{396}$ More generally, the Veblenian perspective preserves an Enlightenment-era egalitarian element in patentable subject matter policy that is presently being eroded in an era in which the values and ideologies of feudalism increasingly regain traction, and also helps preserve technology's positive role as a possibly disruptive social force that can-if conditions are right-fuel progress. ${ }^{397}$ Such limits are important because highly abstracted patent claims directed to invidious,

${ }^{396}$ Here it is worth noting with a careful eye the self-interest of the patent bar, which almost uniformly supports having more patents and patent litigation, leading Chief Justice John Roberts (echoed by Justice Scalia) to joke-in Veblenian fashion-during oral arguments for the KSR case that patent bar support for confusing and low thresholds on the question of nonobviousness "just indicates that this is profitable for the patent bar." Transcript of Oral Argument, KSR Int'l Co. v. Teleflex, Inc., 550 U.S. 398 (2006) (No. 04-1350), available at $\mathrm{http} / / / \mathrm{www}$.patentlyo.com/patent/KSR_20Transcript.pdf; see also Randall R. Rader, Chief Judge, U.S. Court of Fed. Claims, Address at the E.D. Texas Judicial Conference: The State of Patent Litigation (Sept. 2011), transcript available at http://memberconnections.com/olc/filelib/LVFC/cpages/ 9008/Library/

The $\% 20$ State $\% 20$ of $\% 20$ Patent $\% 20$ Litigation $\% 20 \mathrm{w} \% 20$ Ediscovery $\% 20$ Model $\%$ 20Order.pdf ("From the lawyer's perspective, I can give the state of patent litigation in two words: NOT ENOUGH."). Take for instance articles in the trade publication INTELLECTUAL PROPERTY TODAY, which features many articles by patent practitioners. The overwhelming majority of articles in that publication discussing patent-eligible subject matter, and written by practicing patent attorneys, advocate for expanding patent subject matter eligibility and criticize limits or adverse rulings by the judiciary. This follows Veblen's concept of "trained incapacity," which referred to the rather self-serving and often chauvinistic blind spots that professional training often imparts. VEBLEN, THE INSTINCT OF WORKMANSHIP AND THE STATE OF THE INDUSTRIAL ARTS (1914), supra note 8. It is akin to Upton Sinclair's famous saying, "It is difficult to get a man to understand something, when his salary depends upon his not understanding it!" UPTON SINCLAIR, CANDIDATE FOR GOVERNOR: AND HOW I Got LiCKED 109 (U. Cal. Press, 1994) (1935).

397 See DRAHOS WITH BRAITHWAITE, supra note 54, at 198-99; HUDSON, supra note 10, at 156 ("If economic evolution is to reflect the inner logic and requirements of society's technological capabilities, then [neofeudal] finance capital must be subordinated to serve the [real, productive] economy, not be permitted to master and stifle it."). 
pecuniary activities tend to marginalize and dominate over workmanship and technology, rendering practitioners of the "useful arts" decidedly subordinate. Too great a slide toward patents on pecuniary activities may well lead to a feudalistic, preStatute of Monopolies condition in which patents simply divide up entitlements to economic rents. Moreover, patent claims of a pecuniary nature, such as those to a business model per se, bestow preemptive creative monopolies that can potentially discourage technological efforts under the oft-repeated economic incentive theory of patent law, whatever the empirical value of that theory, because claims drawn to more concrete technological activities will nearly always permit the possibility of alternative technological solutions that further contribute to collective knowledge and well-being. The role of technology and industry in society is not a sole determinant of social well-being, but the positive role it can play is perhaps obscured to some degree when an unprincipled expansion of patent-eligible subject matter to nontechnological activity occurs. 